\title{
NIST Special Publication 818
}

\section{Data Bases Available in the Research Information Center of the National Institute of Standards and Technology*} Diane Cunningham

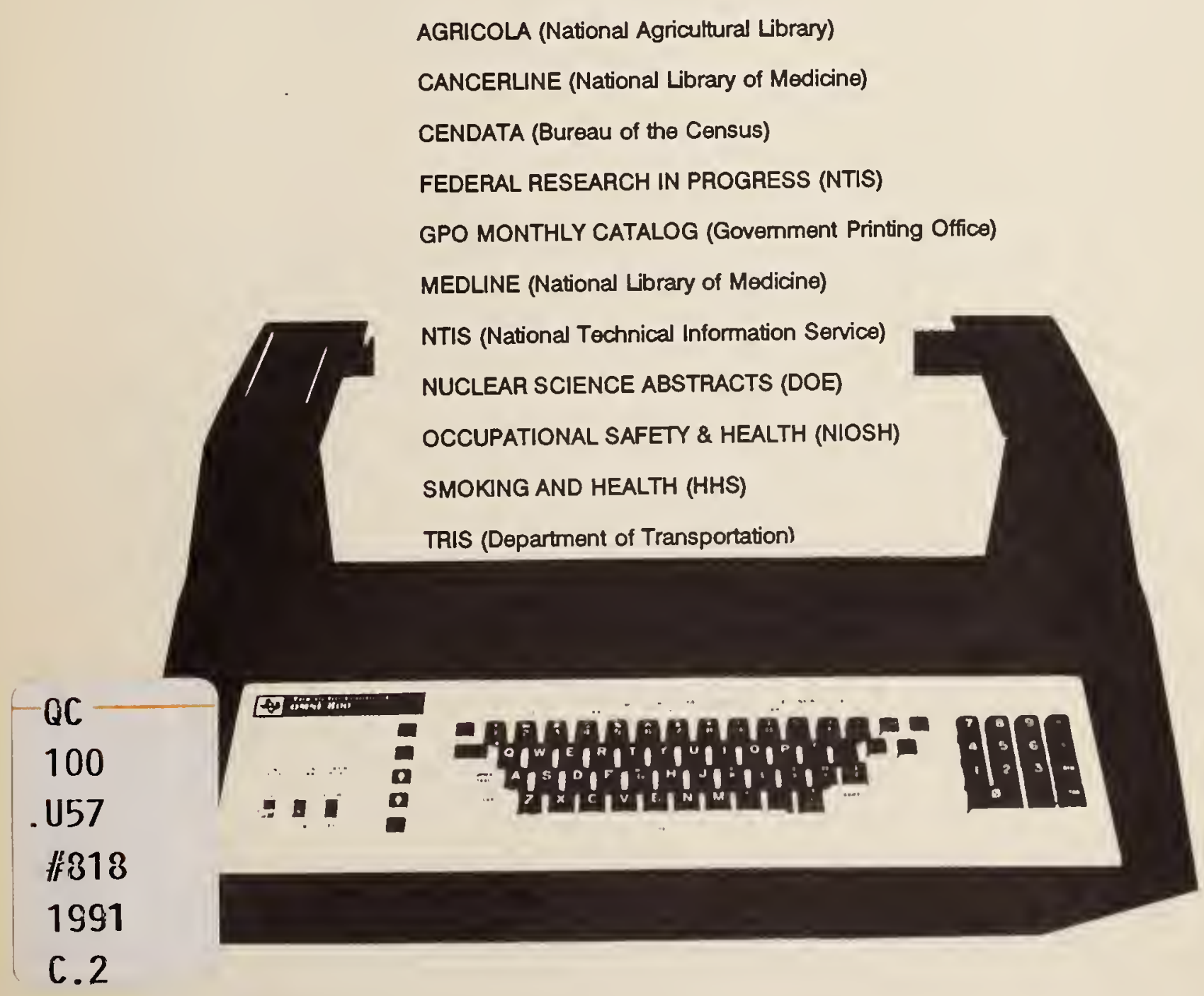





\section{Data Bases Available in the Research Information Center of the National Institute of Standards and Technology*}

${ }^{*}$ Available to NIST Staff and NIST Associates Only

Diane Cunningham

Office of Information Services

National Institute of Standards and Technology

Gaithersburg, MD 20899

September 1991

Supersedes NIST Special Publication 799 (September 1990)

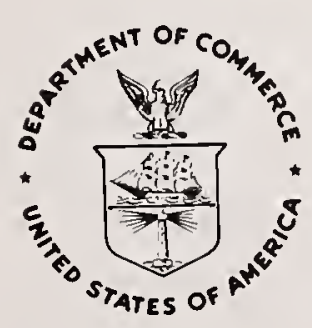

U.S. Department of Commerce Robert A. Mosbacher, Secretary

National Institute of Standards and Technology John W. Lyons, Director 
National Institute of Standards and Technology

Special Publication 818

Natl. Inst. Stand. Technol.

Spec. Publ. 818

128 pages (Sept. 1991)

CODEN: NSPUE2
U.S. Government Printing Office

Washington: 1991
For sale by the Superintendent of Documents

U.S. Government Printing Office Washington, DC 20402 


\section{PREFACE}

This publication supersedes and revises NIST SP 799, which is dated September 1990.

Data bases are listed by acronyms and by full titles. Citations also include dates covered, brief descriptions, kinds of information each contains, producers, the titles of corresponding hard copy, and vendors. A list of vendors with addresses and telephone numbers precedes the list.

The General Subject Index is arranged alphabetically by subject categories and the Cross Reference Index lists variant forms of the names of the data bases in the left column with cross references to the name of the data base used in this publication on the right.

If you are an NIST employee or an NIST associate and are interested in a literature search, call extension 3052 or see an Information Specialist in the Research Information Center. For additions or changes that have occurred since the publication of this report, please contact an Information Specialist.

I wish to thank Karen Jones for her able assistance and diligence in preparing this publication.

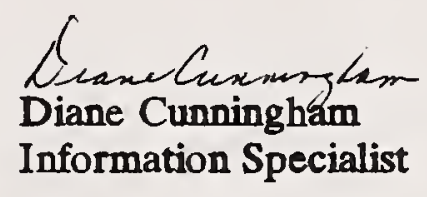





\section{CONTENTS}

Page

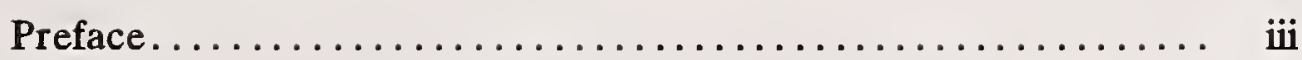

Vendors/Data Base Inquiries.................... vii

List of Data Bases ........................... 1

General Subject Index....................... 88

Cross Reference Index . ....................... 114 



\section{VENDORS/DATA BASE INQUIRIES}

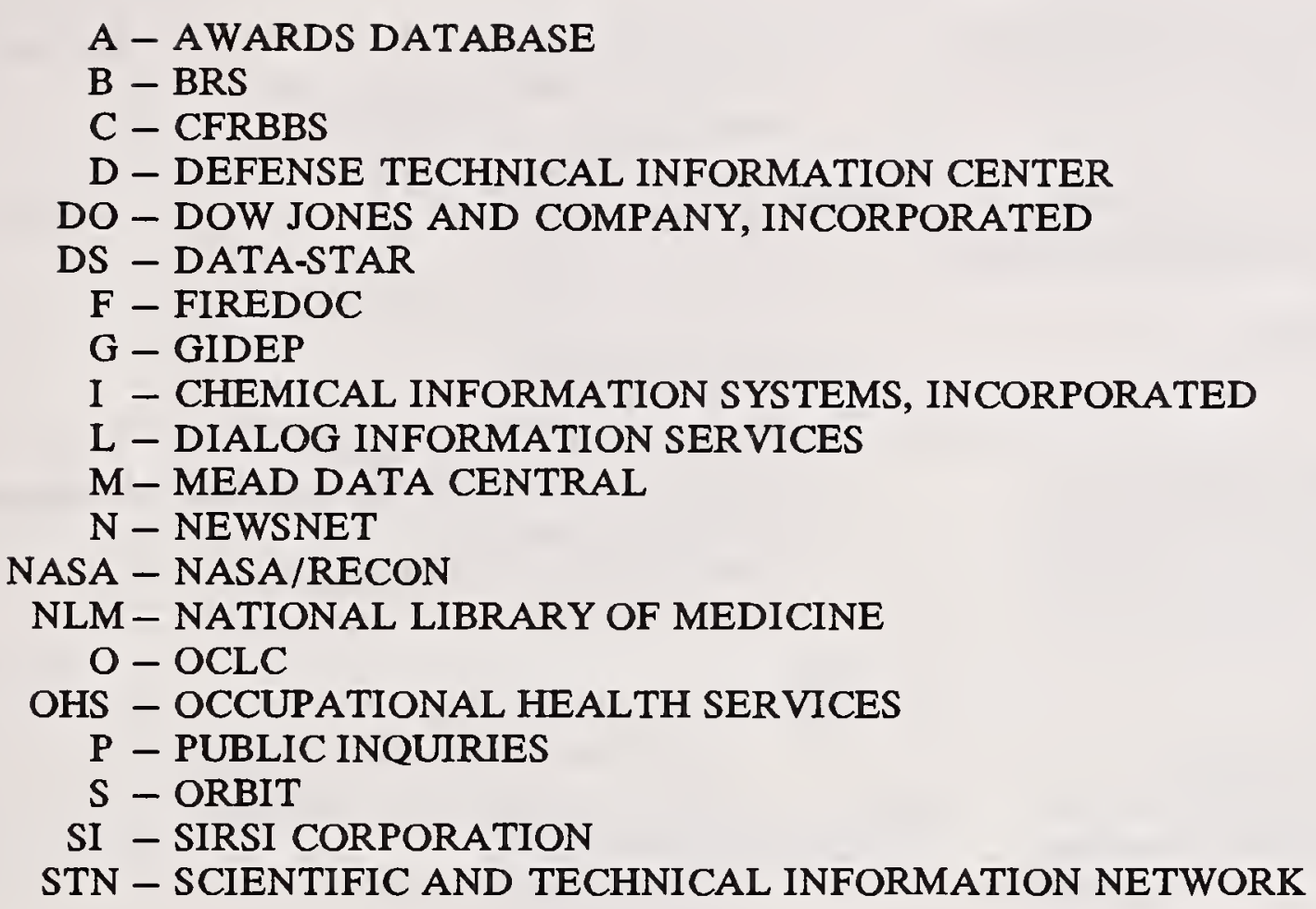

A-AWARDS DATABASE

Sami Klein

Research Information Center

National Institute of Standards and Technology

Bldg. 101 Room E124

Gaithersburg, Maryland 20899

(301) $975-2790$

B-BRS Information Technologies

Maxwell Online, Incorporated

8000 Westpark Drive

McLean, Virginia 22102

(800) 289-4277

C-CFRBBS

W. Douglas Walton

Building and Fire Research Laboratory

National Institute of Standards and Technology

B345 Polymer Bldg.

Gaithersburg, Maryland 20899

(301) 975-6872

D-Defense Technical Information Center

Defense Logistics Agency

Bldg. 5 Cameron Station

Alexandria, Virginia 22304-6145

(202) 274-7633
DO-Dow Jones and Company, Incorporated P.O. Box 300

Princeton, New Jersey 08543-0300

(609) $520-4000$

DS-DATA-STAR

D-S Marketing, Incorporated

Suite 110

485 Devon Park Drive

Wayne, Pennsylvania 19087

(800) 221-7754

F-FIREDOC

Nora H. Jason

Fire Research Information Service

Building and Fire Research Laboratory

National Institute of Standards and Technology

A252 Polymer Bldg.

Gaithersburg, Maryland 20899

(301) $975-6862$

G-GIDEP Operations Center

U.S. Navy

Navy Fleet Analysis Center

Corona, California 91720

(714) $736-4677$ 


\section{VENDORS/DATA BASE INQUIRIES}

I-Chemical Information Systems, Incorporated 7215 York Road

Baltimore, Maryland 21212

(800) CIS-USER

L-DIALOG Information Services, Incorporated 3460 Hillview Avenue Palo Alto, California 94304

(800) 334-2564

M-Mead Data Central, Incorporated

P.O. Box 933

Dayton, Ohio 45401

(513) $865-6800$

$\mathrm{N}-\mathrm{NewsNet}$, Incorporated

945 Haverford Road

Bryn Mawr, Pennsylvania 19010

(800) 345-1301

NASA-NASA/RECON

NASA Center for Aerospace Information

Box 8757

Baltimore/Washington International Airport

Baltimore, Maryland 21240

(301) 621-0300

NLM-MEDLARS Management Section

National Library of Medicine

8600 Rockville Pike

Bethesda, Maryland 20894

(301) 496-6193

$\mathrm{O}-\mathrm{OCLC}$

6565 Frantz Road

Dublin, Ohio 43017-0702

(800) 848-5878

OHS - Occupational Health Services, Incorporated 450 7th Avenue

Suite 2407

New York, New York 10123

(800) 445-6737

P-PUBLIC INQUIRIES

Sami Klein/Peggy Saunders

Research Information Center

National Institute of Standards and Technology

Bldg. 101 Room E124/E128

Gaithersburg, Maryland 20899

(301) $975-2790 / 3058$
S-Orbit Search Service Maxwell Online, Incorporated 8000 Westpark Drive McLean, Virginia 22102

(800) 45-ORBIT

SI-SIRSI CORPORATION STILAS System

Marvin Bond

Research Information Center

National Institute of Standards and Technology

Bldg. 101 Room E216

Gaithersburg, Maryland 20899

(301) 975-2789

STN - STN International

c/o Chemical Abstracts Service

2540 Olentangy River Road

P.O. Box 3012

Columbus, Ohio 43210

(614) 447-3600 


\section{DATA BASES AVAILABLE IN THE RESEARCH INFORMATION CENTER OF THE NATIONAL INSTITUTE OF STANDARDS AND TECHNOLOGY}

DATA BASE AND DATES COVERED
DESCRIPTION/
PRINCIPAL SOURCES

Nonprint media covering all levels of education and instruction/

Audiovisual materials
1964
PRODUCER AND

HARD COPY COUNTERPART

National Information Center for Educational Media (NICEM)
VENDOR AND/OR DATA

BASE INQUIRIES
Detailed information on 149,000 companies in 32 European countries/

$\begin{array}{ll}\text { ABC EUROPE } & \text { Detailed information on } \\ \text { Current } & 149,000 \text { companies in } 32 \\ & \text { European countries/ }\end{array}$

ABC EUROPE
ABC der Deutschen Wirtschaft

DS

Verlags-gesellschaft mbH and Europe Export Edition $\mathrm{GmbH}$ (Germany)
L

$-$

\section{ABC WEST GERMANY \\ Current}

Detailed information on 76,000

German companies and their products/
$\mathrm{ABC}$ der Deutschen Wirtschaft

DS

Veriags-gesellschaft $\mathrm{mbH}$

(Germany)

$\begin{array}{ll}\text { ABI/INFORM } & \text { Literature on all phases of } \\ 1971- & \text { business management and ad- } \\ \text { ministration including accounting, } & \text { data processing, finance, market- } \\ \text { ing, and production/ } & \\ & \text { Journals }\end{array}$

\section{ABLEDATA \\ Current}

ACADEMIC AMERICAN

ENCYCLOPEDIA

1980-
Data Courier, Incorporated

B, DS, L, S business management and ad-

Data Courier, Incorporated

$+2$


ACCOUNTANTS

1974-
International literature in accounting, auditing, taxation, data processing, investments, etc./

Books, speeches, pamphlets, government documents, journals
American Institute of Certified

S

$\mathbf{S}$

Public Accountants

ACCOUNTANTS' INDEX

Literature on all aspects of the sources, causes and effects of acid rain/

Reports, journals, newsletters
Bowker Electronic Publishing

DS
1984
Database in German of business opportunities for small to medium sized companies, mainly European/

Advertisements

\section{ADVERTISE}

Current
Worldwide literature related to aerospace information/

AEROSPACE DATABASE 1962-
Journals, proceedings, books, theses, reports
American Institute of Aeronautics and Astronautics (AIAA), National Aeronautics and Space Administration (NASA)

INTERNATIONAL AEROSPACE

ABSTRACTS, SCIENTIFIC AND TECHNICAL AEROSPACE REPORTS

\section{AERZTE ZEITUNG} 1984
Full text of current information in German on medical trends and management of health services and the pharmaceutical industry/

Newspapers, journals, press releases
Aerzte Zeitung Verlagsgesellschaft DS $\mathrm{mbH}$ (Germany)

\section{AERZTE ZEITUNG}

L

DS

Deutscher Sparkassenverlag

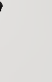


AGRICOLA (AGRICULTURAL ON-LINE ACCESS)

1970-
Worldwide literature in agriculture and related areas/

Journals, monographs, pamphlets, reports, proceedings, translations
U.S. Dept. of Agriculture,

B, L

Science and Education istration

\section{BIBLIOGRAPHY OF AGRI-} CULTURE

Worldwide literature on agriculture with emphasis on the United States/

Journals, books, reports, proceedings
Food and Agriculture

Organization (FAO)/

United Nations

AGRINDEX
L

AGR
Royal Society of Chemistry

L 1983-
Factual data on pesticides such as physical and chemical properties, uses, applications and toxicities/
(U.K.)
Data
AIDS

1983-
Literature on the medical research aspects of AIDS/

Proceedings, reports, books, journals
Bureau of Hygiene and Tropical Diseases (U.K.)
B, DS
Full text file covering all aspects of AIDS
Massachusetts Medical Society

B

1986-

Current information on the

AIDSDRUGS

Current safety and efficiency of drugs

and vaccines being tested as

treatment against AIDS/

Drugs
U.S. National AIDS Information NLM

\section{Clearinghouse}

Literature on AIDS focusing on the biomedical, epidemiological, social, and behavioral areas/

Journals

\section{AIDSLINE}

1980-
National Library of Medicine

DS, L, NLM 
ALCOHOL AND ALCOHOL PROBLEMS SCIENCE DATABASE

1972-
International literature on alcohol and alcohol abuse/

National Institute on Alcohol Abuse and Alcoholism
B

Journals, books, reports, proceed-

ings, unpublished papers

ALCOHOL INFORMATION FOR CLINICIANS AND EDUCATORS DATABASE

1978-
Bibliographic index to the resource collection of the Project CORK Institute of Dartmouth Medical School, originally founded to develop an alcohol curriculum for use in medical schools/

Journals, books, proceedings, reports

\section{Project CORK Institute}

B
Medical Information Service,

DS

Literature covering the

Journals, newspapers, books alternatives to conventional clinical medicine/

British Library (U.K.)

1985-
Nominal composition and composition limits, mechanical and physical properties and minimum tensile properties of commercial wrought aluminum alloys/

Property data

ALUMINUM ASSOCIATION STANDARDS AND DATA 1988
Aluminum Association,

STN
Incorporated

N


AMERICAN CERAMIC

ABSTRACTS

1976-
Literature on all aspects of ceramics/

Journals, proceedings, patents, reports, books
American Ceramic Society

L, S, STN
Information on public, academic, special, and government libraries/

\section{DIRECTORY}

Current
Directory information
AMERICAN LIBRARY DIRECTORY

\section{AMERICAN MEN AND WOMEN OF SCIENCE \\ 1979-}

A listing of names, addresses, and biographical information on U.S. and Canadian scientists/

Biographical data
R. R. Bowker Company L, S

AMERICAN MEN AND

WOMEN OF SCIENCE,

PHYSICAL, AND BIO-

LOGICAL SCIENCES

\section{ANALYTICAL ABSTRACTS} 1982-
Comprehensive literature on analytical chemistry/

Journals, books, proceedings, reports, standards
Royal Society of Chemistry (U.K.)

DS, L, S, STN

\section{ANAL YTICAL ABSTRACTS}

Full text of the national, international and business news from the Associated Press/
The Associated Press

L

News

International coverage of the literature of petroleum and energy-related news items/

Journals
American Petroleum Institute

DS, L, S

\section{INDEX}

1975-

\section{PETROLEUM/ENERGY} BUSINESS NEWS INDEX
L, S, STN

\section{APILIT}

1964
Literature relating to petroleum refining and the petrochemical industry/

Journals, proceedings, reports
American Petroleum Institute 


\section{APIPAT}

1964
Patents relating to petroleum refining and the petrochemical industry issued by the U.S. and eight other countries/
American Petroleum Institute

L, S, STN

Patents

\section{APTIC (AIR POLLUTION TECHNICAL INFORMATION CENTER) 1966-1978}

Worldwide literature on air pollution, it's prevention and control/

\section{U.S. Environmental Protection} Agency
L
Journals, monographs, proceedings, patents, government reports

\section{AIR POLLUTION ABSTRACTS}

\section{U.S. National Oceanic and}

L

Information on the growing of marine, brakish, and freshwater organisms/
Atmospheric Administration

(NOAA)

Journals, monographs, proceedings

\section{AQUALINE}

1960-
Worldwide coverage of all aspects of water research/

Journals, proceedings, books, reports, legislation, pamphlets, translations, standards
Water Research Centre, Medmenham Laboratory (U.K.)

S

WRC INFORMATION
Toxic effects of chemical substances on freshwater and saltwater organisms/

Toxicity data
Chemical Information Systems, Incorporated
I TION RETRIEVAL) 1970-1990
Information on all aspects of political, economic and social life in the Arab world/
ARAB INFORMATION BANK 1983-

Newspapers, journals

Online catalogue of the British Architectural Library covering all aspects of architecture/

Journals, books, reports, proceedings
Royal Institute of British

L
$\mathbf{L}$

\section{8-}

\section{Architects}

ARCHITECTURAL PERIOD-

ICALS INDEX, ARCHITECTURAL BOOKS CATALOGUE 
DATA BASE AND DATES COVERED
DESCRIPTION/

PRINCIPAL SOURCES
PRODUCER AND

HARD COPY COUNTERPART
VENDOR AND/OR DATA BASE INQUIRIES

\section{ART LITERATURE INTERNATIONAL 1973-}

International literature on the history of art/

Journals, books, essays, proceedings, exhibition catalogs, museum publications
RILA, The International

L Repertory of the Literature of Art

RILA

\section{International literature of modern $\mathrm{ABC}$-Clio, Incorporated art and design from 1800 to the present/ \\ Journals, dissertations, exhibition catalogues, books \\ ARTBIBLIOGRAPHIES MODERN \\ ARTBIBLIOGRAPHIES MODERN \\ 1974}

Index to the non-exclusive sources of the consulting firm Arthur D. Little, mainly in the areas of management, technology and industry /

Reports
Arthur D. Little

L ARTH
1977-

\section{Decision Resources}

Literature on all aspects of artificial intelligence/

Journals, proceedings, reports
Bowker Electronic Publishing

DS

\section{ARTIFICIAL INTELLIGENCE ABSTRACTS \\ 1984-}

L 
ASIA PACIFIC

1985-
Business, economics and new industries of the Pacific RIM nations/
Aristarchus Knowledge Industries Incorporated
L

Newspapers, journals, newsletters, proceedings, press releases, monographs

ASSIA: APPLIED SOCIAL SCIENCES INDEX AND ABSTRACTS

1987-
Literature on the applied aspects of the social sciences/

Bowker-Saur Ltd. Abstracts and Indexes (U.K.)
DS

ASSIA: APPLIED SOCIAL SCIENCES INDEX AND ABSTRACTS
AUTOMOTIVE INDUSTRY NEWS

$1987-$
International coverage of news, information and the application of new technologies for the automotive industry /

Newspapers, journals, press releases
PRS Corporate Information DS
A very Index to Architectural Periodicals, Columbia University
L

Literature on all aspects of architecture/

Journals

\section{AVERY INDEX TO ARCHITECTURAL PERIODICALS}

\section{AVLINE (AUDIOVISUAL CATALOG ON-LINE) \\ Current}

Bibliographic information concerning audiovisual materials in the health sciences/

Films, videotapes, slides, recordings
National Library of Medicine

NLM

\section{NLM's AUDIOVISUAL CATALOG}

\section{AWARDS DATABASE Current}

Scientific and technical awards and honors which are conferred by governments, institutions, foundations, associations, and societies worldwide/
National Institute of Standards and Technology (NIST), Research Information Center (RIC) 


\section{BEILSTEIN}

Current edition
Structural and factual database in organic chemistry containing more than 350,000 heterocyclic substances/

Property data
Beilstein Institute for Organic

Chemistry

L, S, STN
BEILSTEIN HANDBOOK OF ORGANIC CHEMISTRY
BIBLE (KING JAMES VERSION) Current
Complete text of the modern day revision of the 1769 Bible/
Thomas Nelson Publisher
L
Bible

\section{BIBLIODATA \\ 1972- \\ Contains publications in German collected by the German Library in Frankfurt/ \\ Books, theses, journals, reports, maps, proceedings}

Deutsche Bibliothek (Germany) STN

GERMAN NATIONAL BIBLIOGRAPHY

Gesellschaft für Biotechnologische DS Forschung mbH (Germany)

\section{BIOTECHNOLOGIE-DAS} JAHR-UND ADRESSBUCH
B, DS, L
BIOBUSINESS

1985-
Information on the business applications of biological and biomedical research/
BioSciences Information Service

Journals, proceedings

\section{BIOCOMMERCE ABSTRACTS AND DIRECTORY \\ 1981-}

News items on the business aspects of biotechnology and the commercial applications of the biological sciences/

Newsletters, newspapers, journals
BioCommerce Data Ltd. (U.K.) DS, L
ABSTRACTS IN BIOCOMMERCE

\section{BIOETHICS}

1973-
Information concerning the ethical and public policy aspects in health care or biomedical research/

Journals, newspapers, monographs, court decisions, bills, laws, audiovisuals
Kennedy Institute of Bioethics,

NLM
BIBLIOGRAPHY OF BIOETHICS 
BIOGRAPHY MASTER INDEX

Current
Keys to locations of biographical information found in biographical directories/

Biographical directories
Gale Research Company

L
BIOGRAPHY AND GENEALOGY MASTER INDEX

\section{BIOQUIP}

Current
Information on manufacturers of biotechnology equipment/

Manufacturer and supplier data
DECHEMA Deutsche Gesellschaft fur Chemisches Apparatewesen (Germany)
ACHEMA YEARBOOK 1988

STN

BioSciences Information Service

B, DS, L, STN

Worldwide literature of the life sciences/

Journals, reports, reviews, symposia, books, bibliographies

\section{BIOLOGICAL ABSTRACTS, BIORESEARCH INDEX, BIOLOGICAL ABSTRACTS/ REPORTS, REVIEWS, MEETINGS}

BIOTECHNOLOGY 1982-
Technical aspects of biotechnology/

Journals, proceedings, patents
Derwent Publications Ltd.

L, S

\section{BIOTECHNOLOGY} ABSTRACTS

\section{BMA PRESS CUTTINGS} 1984-
Information on current medical affairs as reported in the media/

Broadcast programs, newspapers
British Medical Association

(U.K.)
DS $-$
BNA DAILY NEWS 1990
Daily comprehensive news coverage of national and international government and private sector activities/

Journals
Bureau of National Affairs

$\mathbf{L}$
Complete text of the BOND BUYER, a newspaper concerning the U.S. municipal bond industry/

Newspaper
Bond Buyer, Incorporated

L
THE

THE BOND BUYER

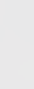

(n)


DATA BASE AND DATES COVERED

BOOKS IN PRINT

Current 2 years
DESCRIPTION/

PRINCIPAL SOURCES
PRODUCER AND

HARD COPY COUNTERPART
VENDOR AND/OR DATA

BASE INQUIRIES
Bibliographic information on print, out of print, and forthcoming book titles/

Books
R. R. Bowker Company
B, L, S

BOOKS IN PRINT, FORTHCOMING BOOKS IN PRINT, SCIENTIFIC AND TECHNICAL BOOKS IN PRINT, MEDICAL BOOKS IN PRINT

\section{BRITISH BOOKS IN PRINT Current}

Comprehensive index of books published in the United Kingdom/

Books
J. Whitaker \& Sons, Ltd.

BRITISH BOOKS IN PRINT

Literature on British education from preschool to adult and higher education/

Journals
L

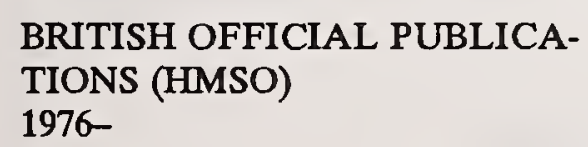

U.K. parliamentary, regulatory and non-parliamentary government and official documents published by HMSO/

Publications catalogs

\section{BUSINESS}

1983-
European database on worldwide trade opportunities, business contacts for manufacturing, marketing, sales, services, etc./

Exhibition catalogs and directories, journals, company profiles, corporate data
University of Leeds (U.K.)

L

\section{BRITISH EDUCATION INDEX, BRITISH EDUCATION THESIS INDEX (Microfiche)}

HMSO Publications Centre (U.K.)
Online GmbH (Germany)

DS

L

L

1983 
BUSINESSWIRE

1986-
Full text of news releases issued by corporations and other organizations/
Business Wire

L

\section{News releases}

BUYERS' GUIDE-MEASUREMENT AND CONTROL

Current
List of measurement and control products manufactured and offered for sale by about 2900 companies in Germany, Switzerland, and Austria
Verlag Hoppenstedt and

DS
Company (Germany)

\begin{abstract}
C13-NMR/IR
\end{abstract}
Current
C13 nuclear magnetic resonance database which identifies organic chemical structures or substructures from their spectra/

Journals, spectral catalogs, unpublished spectra
BASF Aktiengesellschaft

(Germany)
I, STN
Comprehensive literature in agriculture, biology, leisure, recreation, and tourism/
CAB ABSTRACTS (COMMONWEALTH AGRICULTURAL BUREAUX) 1973-
Journals, monographs, reports, patents, proceedings, bibliographies
CAB International

B, DS, L, STN
COMMONWEALTH AGRI-

CULTURAL BUREAUX, JOINT PUBLICATIONS, LEISURE, RECREATION, AND TOURISM ABSTRACTS

\author{
CAD/CAM ABSTRACTS \\ 1984
}

International literature on all aspects of computer-aided design and manufacturing/

Journals, proceedings, reports
Bowker Electronic Publishing

DS, $S$

\section{CAD/CAM ABSTRACTS}

Literature of engineering, computer sciences, electronics and safety research/

Journals, books, proceedings, reports, patents, theses
Cambridge Scientific Abstracts

B

Literature of the life sciences/

Cambridge Scientific Abstracts

$B, L *$

CAMBRIDGE SCIENTIFIC ABSTRACTS LIFE SCIENCE 1981-
Journals, books, proceedings Various abstract sources

* Available in CD-ROM format from the producer from 1988- 
CANADIAN BUSINESS AND CURRENT AFFAIRS 1981-
Canadian company, product, and industry information/

Newspapers, periodicals
Micromedia Ltd. (Ontario)

L
CANADIAN BUSINESS

INDEX, CANADIAN NEWS

INDEX

\section{CANCERLINE (CANCER LITERATURE) \\ 1963-}

Articles related to all aspects of cancer/

Journals, reviews, proceedings, government reports
National Cancer Institute

B, DS, L, NLM

\section{CANCER THERAPY \\ ABSTRACTS, CARCINO- \\ GENEISIS ABSTRACTS}

\section{CANCORP CANADIAN CORPORATIONS \\ Current}

Directory, financial, and textual information on more than 6000 public and private Canadian corporations/
Reports, financial statements Canadian corporations/
Reports, financial statements

CanCorp Canadian Corporations

Database (Canada)
L

\section{CAPREVIEWS \\ Current}

Current chemical literature

6-8 weeks before it appears online in CHEMICAL

\section{ABSTRACTS/}

Journals, proceedings, reports,

books, theses

\section{CAREER PLACEMENT REGISTRY \\ Current}

Listing of college graduates and experienced applicants

looking for job placement/

Resume information
Career Placement Registry

L
STN

\section{CASREACT \\ 1985-}

Literature on organic chemical reactions/

Journals
Chemical Abstracts Service

$-$

\section{CASSI (CHEMICAL ABSTRACTS SERVICE SOURCE INDEX) Current}

Listing of serial and non-serial publications from resource libraries in 28 countries/

Serials, non-serials
Chemical Abstracts Service $S$ 
CATLINE (CATALOG ON-LINE)

1965-
Listing of all monographs and serials cataloged since 1965 at the National Library of Medicine/

Monographs, serials
National Library of Medicine

NLM
Contains assay results and test conditions for 1088 chemicals in the area of carcinogenicity, mutagenicity, tumor promotion and cocarcinogenicity/

\section{CURRENT CATALOG}

\section{Data}

Full text and/or references for all European community legislation/
Commission of the European Communities (Belgium)
DS
DOCUMENTATION SYSTEM ON EUROPEAN COMMUNITY LAW)

1951-

Treaties, journals, reports, debates

CENDATA

Current
Statistical data, press releases and product information from the Bureau of the Census/
U.S. Bureau of the Census

$\mathbf{L}$

Censuses, surveys

CERCLIS

1980-
Listing of U.S. hazardous waste sites/

Directory information
U.S. Environmental Protection

I
Agency

$-$

CESARS (CHEMICAL EVALUATION SEARCH AND RETRIEVAL SYSTEM)

1962-
Detailed information and evaluations on a group of chemicals of importance to the Great Lakes Basin/

Chemical data

\section{CFRBBS}

Current
Computerized bulletin board which includes information on the computer programs, conferences, publications, database and resource directory of the Building and Fire Research Laboratory at NIST/
Michigan State Dept. of Natural Resources
I

(n)

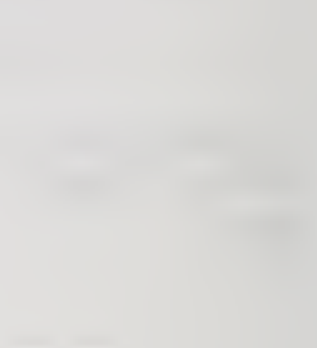

DS 
CHAPMAN AND HALL CHEMICAL DATABASE

Latest edition
Physical/chemical data and bibliographic references to over 175,000 chemical substances/

Property data, journals
Chapman and Hall, Ltd.

L

DICTIONARY OF ORGANIC COMPOUNDS, DICTIONARY OF ORGANOMETALLIC COMPOUNDS and production statistics for
CHEM-INTELL, Chemical

DS, L

Worldwide chemical plant information, trade statistics Intelligence Services (UK)

\section{7-}

more than 100 organic and inorganic chemicals/

Company information

CHEM-INTELL TRADE AND
PRODUCTION STATISTICS
DATABASE
10 years

CHEM-INTELL TRADE AND DATABASE

10 years
Annual trade and production figures for over 100 organic and inorganic chemicals worldwide/
CHEM-INTELL-Chemical Intelligence Services (U.K.)
DS

Statistical publications, journals, reports, tapes

\section{CHEMDEX}

1972-
Compound-oriented file containing registry numbers, molecular formulas, and nomenclatures/
Chemical Abstracts Service S

CHEMICAL ABSTRACTS SUBSTANCE INDEX, CHEMICAL ABSTRACTS REGISTRY HANDBOOK, CHEMICAL ABSTRACTS INDEX GUIDE, CHEMICAL ABSTRACTS FORMULA INDEX

\section{CHEMICAL ABSTRACTS 1967-}

Worldwide literature in chemistry and chemical engineering/

Journals, books, reviews, patents, reports, proceedings, dissertations
Chemical Abstracts Service

B, DS, L, S, STN

\section{CHEMICAL ABSTRACTS}

U.S. Environmental Protection

Lists of chemicals that EPA is studying or has studied in the course of its regulatory or scientific research activities/

\section{Agency}

Chemicals 
CHEMICAL BUSINESS NEWSBASE

October 1984
Covers trends and current affairs in the chemical industry and end-markets/

Journals
Royal Society of Chemistry

DS, L
(U.K.)
DS, L, S
CHEMICAL ENGINEERING AND BIOTECHNOLOGY ABSTRACTS 1970-
Theoretical and practical material in all aspects of chemical engineering/
Royal Society of Chemistry (U.K.)

Journals

CHEMICAL EXPOSURE 1974-1987
Chemicals identified in tissues and body fluids for human, feral and food animals/

Journals, proceedings, letters, reports
Chemical Effects Information

$\mathbf{L}$

Laboratory

CHEMICALS IDENTIFIED IN HUMAN BIOLOGICAL MEDIA, A DATA BASE; CHEMICALS IDENTIFIED IN FERAL AND FOOD ANIMALS, A DATA BASE

\section{CHEMICAL REACTIONS DOCUMENTATION SERVICE 1942-}

Worldwide literature on novel organic chemical reactions, reagents synthetic methods and data/

Journals, patents
Derwent Publications Ltd.

\section{$S$}

JOURNAL OF SYNTHETIC METHODS
Guide to U.S. government regulatory material relating to the control of chemical substances/

Regulations
L

CRC Systems, Incorporated AND GUIDELINES SYSTEM May 1981-
Heal th and safety effects of hazardous chemicals encountered by employees in industry and laboratories/
Royal Society of Chemistry (UK)
DS, L, S, STN

\section{NEWSBASE}

1981-

Journals, books, proceedings

Chemical dictionary/

thesaurus/

Chemical data
National Library of Medicine

NLM

Current 
CHEMLINE (CHEMICAL DICTIONARY ON-LINE)

Current
Chemical names, formulas, synonyms, registry numbers/
National Library of Medicine

NLM
CHEMLIST

1979
Listing of chemical substances on the EPA TSCA inventory or subject to regulation under the TSCA/

TSCA chemistry data, Federal Register data, TSCATS database
American Petroleum Institute

STN
Chemical names, formulas, synonyms, registry numbers/
Chemical Abstracts Service

L

1972-

Chemical substance nomenclature

Automated catalog of commercially available research chem-

Molecular Design Ltd.

S

\section{Current}

icals/

Catalogs

Full text of stories published in the Chicago Tribune/

Newspaper

English language material on the literature of child abuse and neglect/

Journals, on-going research, reports, service program listings, laws, audiovisual materials
Chicago Tribune Company

L CHICAGO TRIBUNE

National Center for Child

L
CHILD ABUSE AND NEGLECT 1965-
Bibliographic information on all patent applications published under the new Chinese patent law/

Patents
Patent Documentation Service

L, S

People's Republic of China

PATENT ABSTRACTS OF CHINA

\section{CHRIS (CHEMICAL HAZARD RESPONSE INFORMATION SYSTEM) \\ Current}

Information on 1016 hazardous chemicals such as properties, health hazards, and first aid/
U.S. Coast Guard 
CIN (CHEMICAL INDUSTRY

NOTES)

1974
Business-oriented literature in Chemical Abstracts Service

DS, L, S, STN the chemical industry/

Journals

CHEMICAL INDUSTRY NOTES

Index and abstracts of U.S. congressional publications/

INFORMATION SERVICE) 1970-
Congressional Information Service
Hearings, reports, documents, CIS INDEX public laws
American Society of Civil Engineers
L
Literature on all aspects of civil engineering/
DATABASE

1975-
Books, proceedings, journals, reports, standards, news
American Chemical Society

STN

Full text of American Chemical

Society journals/

Journals

Various ACS Journals

\section{CJAOAC}

1987-
Full text of papers included in JOURNAL OF THE ASSOCIATION OF OFFICIAL ANALYTICAL CHEMISTS/

Journal

Full text of four chemical journals published by Elsevier/

Journals
Association of Official Analytical STN Chemists

JOURNAL OF THE ASSOCIATION OF OFFICIAL ANALYTICAL CHEMISTS
CJELSEVIER

Jan. 1990-
Elsevier Science Pub. B.V.

STN
ANALYTICA CHIMICA ACTA, APPLIED CATALYSIS, CARBOHYDRATE RESEARCH, JOURNAL OF ORGANOMETALLIC CHEMISTRY
CJRSC 1987-
Full text of the chemical journals of the Royal Society of Chemistry/

Journals
Royal Society of Chemistry (U.K.)
Various Royal Society journals 
CJVCH

1988-
Full text of papers in ANGEWANDTE CHEMIE/

Journal

Full text information from polymer journals/

Journals
VCH Verlagsgesellschaft

(Germany)
STN

\section{ANGEWANDTE CHEMIE}

John Wiley and Sons, Incorporated STN

1987-

CJWILEY
A listing of U.S. patents and cited references/

IFI/Plenum Data Company

1947-

Patents
L, S, STN

Various Wiley journals$$
\mathrm{L}, \mathrm{S}, \mathrm{STN}
$$

CLAIMS/PATENTS
1950

A series of files listing U.S. patents issued by the U.S. Patent and Trademark Office/

Patents
IFI/Plenum Data Company

L, S, STN
U.S. PATENT OFFICIAL GAZETTE

\section{CLAIMS/REFERENCE}

Current
Dictionary index to the U.S.

Patent Office's classification codes/

Patents
IFI/Plenum Data Company

L, S, STN
Covers research and factual information on many aspects of coffee/

Journals, reports, books, patents, theses, audiovisual material
International Coffee Organization

L 1973-
Balance sheets, profit/loss accounts and rations of Germany's biggest industrial trading and service companies/
(U.K.)

ICO LIBRARY MONTHLY ENTRIES

\section{COIN-NUMERIC 1984}

Annual reports

Gesellschaft fur betriebwirtschaft- DS liche Information $\mathrm{mbH}$

\section{COLD REGIONS 1951-}

Worldwide literature pertaining to snow, ice, permafrost, and frozen ground and their relation to civil engineering, navigation, and transportation/

Reports, journals, books, proceedings, patents
Cold Regions Research and Engineering Laboratory of the U.S. Army Corps of Engineers/ Library of Congress

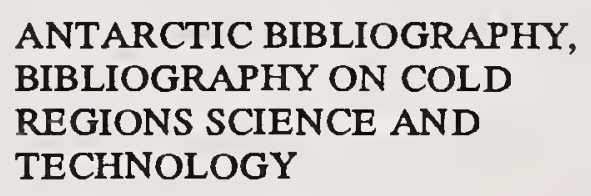
BIBLIOGRAPHY ON COLD REGIONS SCIENCE AND TECHNOLOGY 
COMBINED HEALTH INFORMATION DATABASE

1977- (varies)
Information on arthritis, diabetes, health education, digestive diseases and high blood pressure/

Journals, pamphlets, monographs, audio-visuals, reports, proceedings
Combined Health Information B Database
B
Announcements of products and U.S. Dept. of Commerce
services wanted or offered by
the U.S. government/
$\begin{aligned} & \text { Contract awards or announce- } \\ & \text { ments }\end{aligned}$
L

\section{COMMERCE BUSINESS DAILY October 1982-}

Directory information and news coverage for 100,000 private and public businesses/
Information Access Company

L

\section{Current}

COMPANY INTELLIGENCE

Current

Journals, questionnaires, interviews, directories

\section{COMPENDEX (ENGINEERING INDEX)}

1970-
Worldwide engineering and technological literature/

Journals, transactions, proceedings, government reports
Engineering Information, Incorporated
B, DS, $L^{*}, S, S T N$

\section{ENGINEERING INDEX}

Access to the complete text of Various publishers

B prominent medical textbooks/ MEDICAL LIBRARY

Current

Textbooks

Literature of computer science

FIZ-Karlsruhe

STN 1972and technology/

Journals

COMPUTER AND MATHEMATICS SEARCH 1980-
Literature in mathematics, computer science, statistics, operations research and related fields/

Journals
Institute for Scientific Information

\section{B}

COMPUMATH CITATION INDEX

\footnotetext{
* Available also in CD-ROM format from 1988-
} 
DATA BASE AND DATES

COVERED
DESCRIPTION/

PRINCIPAL SOURCES
PRODUCER AND

HARD COPY COUNTERPART
VENDOR AND/OR DATA

BASE INQUIRIES
THE COMPUTER DATABASE 1983-
Technical and consumer informa- Information Access Company tion on computers, telecommunications and electronics/

Journals, newsletters, proceedings
COMPUTER INDUSTRY SOFTWARE, SERVICES AND PRODUCTS 1989-
Full text information on computer industry software, services and products/

Journals
Janet Matthews Information

DS
B, DS, L Services (U.K.)

PERSONAL COMPUTER

MARKETS; SOFTWARE

MARKETS; COMPUTER

PRODUCT UPDATE

Computer news and develop- Ziff Communications

$*$

COMPUTER LIBRARY

Most recent 12 months ments/

Journals

Full text of COMPUTERWORLD and NETWORK WORLD/

Journals
IDG Communications

L

\begin{abstract}
1989-
\end{abstract}
COMPUTER NEWS FULLTEXT
Detailed information on publicly available databases/
Gale Research Incorporated

L

COMPUTER-READABLE
DATABASES
Current

DATABA
Current

Databases
COMPUTERWORLD; NETWORK WORLD

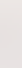


CONGRESSIONAL RECORD ABSTRACTS

1981-
Comprehensive legislative infor- National Standards Association B, L mation from CONGRESSIONAL RECORD/

Bills, amendments, speeches, floor actions
CONGRESSIONAL RECORD
CONSUMER DRUG INFORMATION FULLTEXT

Current
Full text drug descriptions written in everyday language for the consumer patient/

Drug information
American Society of Hospital

Pharmacists

B, L

\section{CONSUMER DRUG DIGEST}

Complete text of major articles from CONSUMER REPORTS/

Journal
Consumers Union

L
Directory information on businesses and corporate linkages to parent organizations/

Directory information

\section{CONSUMER REPORTS}

Current
Index to company and industry research reports issued by major U.S. and Canadian securities and institutional investment firms/

Reports
J A Micropublishing, Incorporated

\section{B} RESEARCH REPORTS ONLINE INDEX 1982-
National Register Publishing

$\mathbf{L}$

\section{Company}

RESEARCH REPORTS INDEX

Corporate Technology Information $S$

Services, Incorporated

Profiles on over 30,000 U.S.

develop high technology

products/

Directory information/
CORPORATE TECHNOLOGY DIRECTORY

\section{CORROSION}

Current
Corrosive data covering the ef- Marcel Dekker

$S$ fects of over 600 agents on metals, carbons, glass, plastics and rubber/

Data
CORROSION RESISTANCE

TABLES: METALS, PLASTICS, NONMETALLICS AND RUBBERS 
COUNTRY REPORT SERVICES

Current
Full text of publications on the political and economic climates in countries/

Reports
Political Risk Service

DS

\section{CRIMINAL JUSTICE PERIOD-} ICAL INDEX 1975-
Covers areas of criminology, criminal law, security systems, corrections and police/

Journals
University Microfilms International L

CRIMINAL JUSTICE PERIODICAL INDEX

USDA, Current Research

L
Listing of current research projects in agriculture and related subjects/
Information System

\section{$\begin{array}{lll}\begin{array}{l}\text { CREDITREFORM } \\ \text { Current }\end{array} & \begin{array}{l}\text { Information in German on West } \\ \text { German companies/ }\end{array} & \begin{array}{l}\text { Verband der Vereine Creditreform DS } \\ \text { e.v. (Germany) }\end{array} \\ & \text { Questionnaires, business data } & -\end{array}$ \\ $\begin{array}{llc}\begin{array}{l}\text { CREDITREFORM } \\ \text { Current }\end{array} & \begin{array}{l}\text { Information in German on West } \\ \text { German companies/ }\end{array} & \begin{array}{l}\text { Verband der Vereine Creditreform DS } \\ \text { e.v. (Germany) }\end{array} \\ & \text { Questionnaires, business data } & -\end{array}$ \\ $\begin{array}{llc}\begin{array}{l}\text { CREDITREFORM } \\ \text { Current }\end{array} & \begin{array}{l}\text { Information in German on West } \\ \text { German companies/ }\end{array} & \begin{array}{l}\text { Verband der Vereine Creditreform DS } \\ \text { e.v. (Germany) }\end{array} \\ & \text { Questionnaires, business data } & -\end{array}$ \\ $\begin{array}{llc}\begin{array}{l}\text { CREDITREFORM } \\ \text { Current }\end{array} & \begin{array}{l}\text { Information in German on West } \\ \text { German companies/ }\end{array} & \begin{array}{l}\text { Verband der Vereine Creditreform DS } \\ \text { e.v. (Germany) }\end{array} \\ & \text { Questionnaires, business data } & -\end{array}$ \\ $\begin{array}{llc}\begin{array}{l}\text { CREDITREFORM } \\ \text { Current }\end{array} & \begin{array}{l}\text { Information in German on West } \\ \text { German companies/ }\end{array} & \begin{array}{l}\text { Verband der Vereine Creditreform DS } \\ \text { e.v. (Germany) }\end{array} \\ & \text { Questionnaires, business data } & -\end{array}$ \\ Profiles of Austrian companies/ \\ Current \\ Verband der Vereine Creditreform DS e.v. (Germany) \\ Questionnaires, data from official sources

(n)

\section{CRIS/USDA}

Current
Research projects

\section{CRSP (COMPUTER RETRIEVAL OF INFORMATION ON SCIENTIFIC PROJECTS) Current}

Research projects in progress that are supported by the U.S. Public Health Service/
Research Documentation Section

B

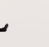
(1)

\begin{tabular}{llll} 
& Research projects & \multicolumn{1}{l}{ STN } \\
$\begin{array}{l}\text { CSCHEM } \\
\text { Current }\end{array}$ & $\begin{array}{l}\text { Catalog file containing informa- } \\
\text { tion about chemical products and } \\
\text { their suppliers/ } \\
\text { Catalog information }\end{array}$ & $\begin{array}{l}\text { Directories Publishing Company, } \\
\text { Incorporated }\end{array}$ & CHEM SOURCES-USA \\
\hline $\begin{array}{l}\text { CSCORP } \\
\text { Current }\end{array}$ & $\begin{array}{l}\text { Directory information about } \\
\text { companies that supply chemicals } \\
\text { and chemical products/ }\end{array}$ & $\begin{array}{l}\text { Directories Publishing Company, } \\
\text { Incorporated }\end{array}$ & STN \\
Directory information & CHEM SOURCES-USA & \\
\hline
\end{tabular}


CTCP (CHEMICAL TOXICOLOGY Listing of manufacturers, trade OF COMMERCIAL PRODUCTS) 1984 names, uses, and ingredients of commercially available products/

Data
Chemical Information Systems,

Incorporated

CLINICAL TOXICOLOGY OF COMMERCIAL PRODUCTS
I

Cuadra/Elsevier

DS, S

\section{CUADRA DIRECTORY OF ONLINE DATABASES \\ Current}

Information about online databases/

Databases

\section{DIRECTORY OF ONLINE} DATABASES
Listing of worldwide biological literature/
Current Awareness in Biological Sciences
B

\section{BIOLOGICAL SCIENCES}

1983-

\section{Journals}

\section{CURRENT BIOTECHNOLOGY} ABSTRACTS

1983-
Literature on the scientific, technical and technocommercial aspects of biotechnology/

Journals
Royal Society of Chemistry

$$
\text { (U.K.) }
$$

DS, L, S
Table of contents of journals in the areas of life sciences, physical sciences, engineering, agriculture, and biology/

Journals

Translations and abstracts from Soviet newspapers and magazines/
Newspapers, magazines

\section{magazines/}

\section{Insti}

Institute for Scientific Information
B, $L$

for Scientific Information
CURRENT DIGEST OF THE SOVIET PRESS

1982-

\section{CURRENT CONTENTS}

The Current Digest of the Soviet L Press

\section{CURRENT DIGEST OF THE} SOVIET PRESS
CURRENT PATENTS EVALUATIONS October 1990
Evaluation of key pharmaceutical Current Patents Ltd. patents/

Patents

\author{
CURRENT CARDIOVASCULAR \\ PATENTS, CURRENT ANTI- \\ MICROBIAL PATENTS, \\ CURRENT CNS PATENTS
}



CURRENT PATENTS FAST-
Current pharmaceutical patents/
Current Patents Ltd.
DS, S
ALERT

1989-

Patents

CURRENT TECHNOLOGY

INDEX

1981-
Literature on all fields of modern The Library Association (U.K.)

L technology from journals published in Great Britain/

Journals
CURRENT TECHNOLOGY

INDEX, CATCHWORD AND

TRADE NAME INDEX

\section{D\&B-CANADIAN DUN'S MARKET IDENTIFIERS \\ Current}

Financial data for 350,000

Canadian companies/

Dun's Marketing Services

L

Business data

\section{D\&B DONNELLEY \\ DEMOGRAPHICS \\ 1980 census data}

Demographic data from the 1980 census/

Demographic data
Donnelley Marketing Services

L
Directory information for nearly

8.5 million businesses and professionals throughout the United States/
Dun's Marketing Services

L

\section{BUSINESS DIRECTORY}

Current

Data from interviews

D\&B-DUN'S FINANCIAL RECORDS PLUS Current private and public business establishments/

Financial data
Financial information on U.S.

Dun's Marketing Services

L

Directory file containing address,

Dun's Marketing Services

L

\section{D\&B-DUN'S MARKET \\ IDENTIFIERS \\ Current}

financial and marketing information on U.S. business establishments/

Financial and marketing data

\section{D\&B-EUROPEAN DUN'S MARKET IDENTIFIER'S \\ Current}

Directory listings for over $1,500,000$ businesses in 29 European countries/
Dun's Marketing Services

DS, L

Interviews 
D\&B-INTERNATIONAL DUN'S MARKET IDENTIFIERS

Current
Directory listing with sales volume and marketing data for leading companies throughout the world/

Directory information, marketing data
Dun's Marketing Services

DS, L
Information on U.S. commercial and industrial establishments having net worth of orle-half

million dollars or more/
Information from questionnaires
Dun's Marketing Services

L

\section{DIRECTORY}

Current
MILLION DOLLAR DIRECTORY

DATAMONITOR MARKET
REPORTS
Current

DATAMONITOR MARKET

Current
Analysis and forecasts for over 400 market sectors in the U.K., Europe, and the U.S.I

Reports, interviews, surveys
Datamonitor (U.K.)

DS
DS
Information on companies in the new German Federal States/

Company data
Deutsche Bank AG (Germany)

Current
Reports on drugs from 1200 major Paul de Haen International, international biomedical journals/ Incorporated

Journals
DE HAEN'S DRUG DATA 1980
References to the German and international literature in the fields of chemical technology, biotechnology, chemical equipment, pollution control and safety technology/

Journals, reports, proceedings, books

\section{DECHEMA (Deutsche} Gesellschaft fur Chemisches Apparatewesen)
L -
DECHEMA

1975-
French database on international markets, products, industries and companies/

Journals, newspapers, books, directories, reports
Reseau APCCI (France) Reseau CCIP (France)
DELP
$1980-$

directories, reports


DELPHES EUROPEAN BUSINESS 1980
French database on international markets, products, industries, and companies/

Journals, newspapers, books, reports, market studies
Paris Chamber of Commerce and Industry (France)
L
Summaries of ongoing dental research projects/

Ongoing research projects
National Institute of Dental Research
NLM

DENTAI
Current

DENTALPROJ
DEQUIP (DECHEMA EQUIPMENT Information on manufacturers of SUPPLIER DATA BANK) Current apparatus and technical equipment in the fields of chemical engineering and biotechnology/

\section{Data}

Information on research institutes in the area of chemical technology

DECHEMA (Deutsche Gesellschaft für Chemisches Apparatewesen)

ACHEMA YEARBOOK

DECHEMA Deutsche

STN

STN Gesellschaft für Chemisches Apparatewesen (FRG) INSTITUTES) Current

Directory information

Dermal absorption of chemical substances/
U.S. Environmental Protection

I Agency, Office of Pesticides and Toxic Substances

Chemical data

DETEQ (DECHEMA ENVIRONMENTAL TECHNOLOGY EQUIPMENT DATA BANK)

Current
Information on manufacturers of apparatus and technical equipment in the fields of environmental engineering/

Data

\section{DEUTSCHE PATENT DATEN- BANK (GERMAN PATENT DATABASE) 1981-}

Bibliographic data in German on patent documents and utility models published by the German patent office/
DECHEMA (Deutsche Gesellschaft für Chemisches Apparatewesen)

ACHEMA HANDBOOK POLLUTION CONTROL
STN

Deutsches Patentamt

STN

Patents 
DHMT

1888-
Medical toxicology and environmental health/
Dept. of Health, Medical Toxicology and Environmental Health Div. (U.K.)
DS

Journals, proceedings, reports, books, pamphlets

DHSS-DATA

1983-
Online database of the Department of Health and Social Security Library in London/

Journals, books, reports, pamphlets
Department of Health and Social

DS
Menu-driven price and rate quotation and news service covering major U.S. and international cash futures and options markets /

Exchanges, banks, mortgage bankers, reporters
Knight-Ridder Financial

$\mathbf{L}$

\section{Information}

Gateway service which provides stock and option quotes from the New York and American Stock Exchange, NASDAQ and the four major option exchanges/
Trade Plus

L

\section{TRADING}

Current

Stock exchange quotes

\section{DIOGENES}

Current
Full text of published and unpublished regulatory information concerning the health care industry /

Regulations, newsletters
FOI Services, Incorporated

B, DS, L
Textual information and numeric physical property data for commercially important chemical substances/

Chemical data
American Institute of Chemical

\section{STN}

FOR PHYSICAL PROPERTY

DATA)

1982-

\section{Engineers}

R R Bowker Company

$S$
DIRECTORY OF AMERICAN RESEARCH AND TECHNOLOGY Current
Listing of the research and development capabilities of industrial organizations in the United States/

Questionnaires 
DIRLINE (DIRECTORY OF INFORMATION RESOURCES ONLINE)

Current
Directory of organizations providing information in specific subject areas/

Directory information
National Library of Medicine

NLM
Information extracted from reports filed with the SEC by 10,000 publicly-held companies/
Disclosure, Incorporated

B, DS, L
DISCLOSURE

Current

Reports

\section{DISCLOSURE/SPECTRUM OWNERSHIP \\ Current}

Detailed and summary ownership information for about 5000 public companies/
Disclosure, Incorporated

B, L

Data

Listing of doctoral and master dissertations granted by U.S. universities and other countries/
University Microfilms International B, L

\section{ONLINE}

1861-

\section{Dissertations}

\section{DISSERTATION ABSTRACTS INTERNATIONAL, AMERICAN DOCTORAL DISSERTATIONS}

\section{DKF DATABASE VEHICLE TEST REPORTS 1979-}

Information on vehicle tests taken from about 70 international journals/

Journals
Dokumentation Kraftfahrwesen e.v. DS

\section{DMS CONTRACT AWARDS FY1981-}

Comprehensive listing of nonclassified U.S. government prime contracts of $\$ 25,000$ or more /

Contracts
DMS Incorporated

L

DMS Incorporated

L

\section{DMS CONTRACTORS 1969-}

Companies involved in U.S. and international defense/aerospace programs/

Unclassified information sources 
DOW JONES NEWS/RETRIEVAL Full text of business and financial 1979 -(varies) news/

Newspapers, journals
Dow Jones and Company, Incorporated

WALL STREET JOURNAL, WASHINGTON POST, BARRON'S, MCGRAW-HILL BUSINESS LIBRARY, etc.

\section{DROLS (DEFENSE RDT $+\mathrm{E}$ ON-LINE SYSTEM) 1953-}

Multidisciplinary coverage of classified and unclassified technical reports generated by U.S. government sponsored research; also includes publications of NIST's National Standard Reference Data System (NSRDS)/

Reports
Defense Technical Information Center (DTIC)

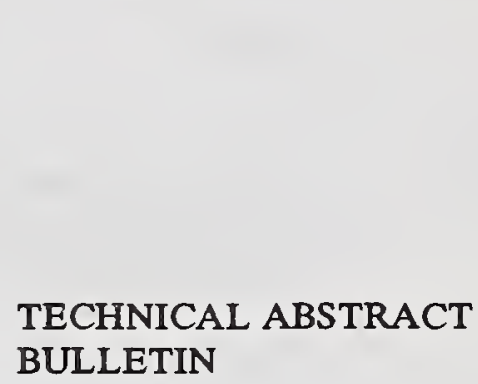

DO

D

Drug Information Service

B

Diversified coverage of the drug abuse literature/

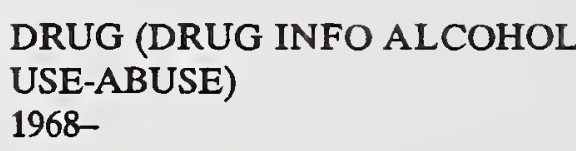

Journals, reviews, unpublished reports

\section{DRUG INFORMATION \\ FULLTEXT \\ Current}

Information on drug uses, precautions, interactions, dosages, etc./

Books
American Society of Hospital B, I, L Pharmacists

HANDBOOK ON INJECTIBLE DRUGS; AMERICAN HOSPITAL FORMULARY SERVICE DRUG INFORMATION
DRUG PATENTS INTERNATIONAL Current
Evaluated drug patent information by country/

Patents
IMSWORLD Publications, Ltd. (U.K.)

Patents International

\section{DRUGNEWS}

Current
Literature on drugs, drug therapy and adverse drug experiences/

Journals, press releases, reports, proceedings
ADIS International

B, DS

INPHARMA, REACTIONS, BIOINPHARMA 
EAST EUROPEAN CHEMICAL MONITOR

1984
Business information from the chemical industry sector/
Business International (Austria)

DS

Journals

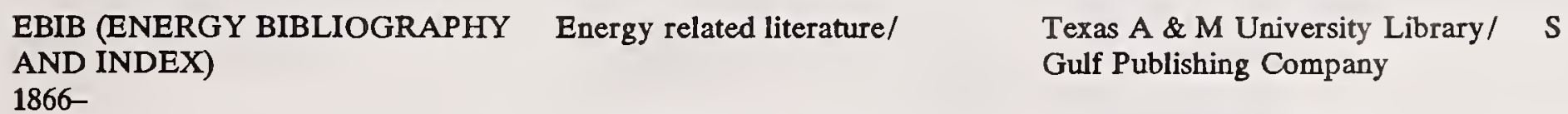

Reports, vertical file information ENERGY BIBLIOGRAPHY

AND INDEX

$\begin{array}{ll}\begin{array}{l}\text { EBIS-EMPLOYEE BENEFITS } \\ \text { INFOSOURCE }\end{array} & \begin{array}{l}\text { Comprehensive information on } \\ \text { all facets of employee benefit }\end{array} \\ \text { 1986- } & \text { plans/ } \\ & \begin{array}{l}\text { Journals, newspapers, newsletters, } \\ \text { reports, news releases, proceedings }\end{array}\end{array}$

International Foundation of

L

Employee Benefit Plans

1866-

reports, news releases, proceedings

\begin{abstract}
ECER (EXCEPTIONAL CHILD EDUCATION RESOURCES) 1966-
\end{abstract}

Published and unpublished literature on education of handicapped and gifted children/

Journals, monographs, reports
Council for Exceptional Children

B, L

EXCEPTIONAL CHILD

\section{EDUCATION ABSTRACTS} and psychology/

Journals, reports, monographs, thesis
B

Literature of the applied social sciences including economics, geography, sociology, education,

$\mathrm{CAB}$ International MENT AND EDUCATION) 1980-
Compilation of critical economic data used for researching, monitoring and reporting economic, financial and industry specific trends/

Statistical data
Chase Econometrics

L

ECON BASE: TIME SERIES AND
FORECASTING
1948-

L

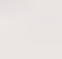


ECONOVO

1985-
Legal announcements in German

Ecodata Wirtschaftsinformationen

DS an companies publish

the official gazette of the Ministry

of Justice /

Company information

Information in German on

German companies published

in the official gazette of the

Ministry of Justice/

Company information
BUNDESANZEIGER

Ecodata (U.K.)

DS

BUNDESANZEIGER

\section{THE EDUCATIONAL DIRECTORY \\ Current}

Directory listing of every school district, college, and public library in the United States/

Directory information
Dun's Marketing Services

L

\section{CIC'S SCHOOL DIRECTORY}

Educational Testing Service Test Collection
B

Descriptions of tests, evaluation tools and assessment/screening devices for measuring skills, aptitudes, interests, etc./

\section{SERVICE FILE}

Current
Tests

\section{ELECTRO/ELECTRONICS BUYERS' GUIDE \\ Current}

Listing of electrical and electronic products manufactured and offered for sale by about 1,950 companies in Germany/
Verlag W. Sachon, GmbH and Company (Germany)

DS

\section{ELECTRONIC MATERIALS INFORMATION SYSTEM 1982-}

Latest data on properties of materials important in the fields of microelectronics and solid state research/
INSPEC, Institution of Electrical B Engineers

Journals

Literature in electronic publishing PIRA (U.K.)

ELECTRONIC PUBLISHING ABSTRACTS 1975and information technology/

Journals, books, proceedings, standards, reports 
EMBASE

June 1974
Worldwide biomedical literature/ Excerpta Medica

B, DS, L

Journals, books, proceedings

\section{EXCERPTA MEDICA, DRUG LITERATURE INDEX}

Gale Research Company

$\mathbf{L}$

ENCYCLOPEDIA OF
ASSOCIATIONS
Current

Current
Descriptive information on nonprofit American membership

organizations of national scope/

Directory information obtained from questionnaires

ENERGIE

1976-
Literature on energy research and technology published in

German speaking countries/

Journals, reports, books, patents, proceedings

THE ENCYCLOPEDIA OF ASSOCIATIONS

FIZ Karlsruhe (Germany)

STN

International literature on energy and related fields/

Reports, books, proceedings, patents, journals
Department of Energy, Technical Information Center

ENERGY RESEARCH ABSTRACTS, ENERGY ABSTRACTS FOR POLICY ANALYSIS

$\begin{array}{ll}\text { ENERGYLINE } & \begin{array}{l}\text { Comprehensive coverage of as- } \\ \text { pects of energy and environment/ }\end{array} \\ & \begin{array}{l}\text { Journals, reports, monographs, } \\ \text { hearings }\end{array}\end{array}$

ENERGYLINE hearings
R. R Bowker Company
L, S

ENERGY INFORMATION ABSTRACTS, ENVIRONMENT ABSTRACTS

\section{ENGINEERED MATERIALS ABSTRACTS (EMA) \\ 1986-}

World's literature on polymers, ceramics, and composites/

Journals, proceedings, reports, books, theses, patents
Materials Information

L, S, STN 
ENVIROFATE

1970
Environmental fate or behavior of chemical substances released into the environment/

Environmental data
U.S. Environmental Protection

Agency, Office of Pesticides

and Toxic Substances
Worldwide coverage of literature in environmental studies/

Journals, new releases, reports, patents, films
R. R. Bowker Company

L, S
1971-
Literature of general human ecology, atmospheric studies, energy, land, and water resources,

\section{ENVIRONMENT ABSTRACTS}

Environmental Studies Institute
GRAPHY (EPB)

1973- health, and nutrition/

Journals
ICALS BIBLIOGRAPHY
ENVIRONMENTAL PERIOD-
EPD (ELECTRIC POWER DATA

1972-
BASE)
Summaries of ongoing and completed research projects in the electric utility industry/

Research projects
Electric Power Research Institute
$\mathbf{L}$

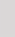

$s$


EUROPEAN CHEMICAL NEWS 1987-
Current news on chemicals and related industries/

Journal
European Chemical News (U.K.)

DS
Data on pesticide products registered in Europe for use in agriculture, horticulture and pest control/

Manufacturing data
The Royal Society of Chemistry

L
AGROCHEMICAL PRODUCTS

Current
Information on market research

MARKET RESEARCH ASSOCIA- for the pharmaceutical industry/

\section{(U.K.)}

DS

The Research Group (U.K.)

TION DATABASE

1988-

Journals, market research reports

Listing of current and future international conferences, trade fairs, exhibitions, and major sports events/

Primary and secondary sources; Elsevier's publications
EVENTLINE

Current
Detailed articles covering the full range of human knowledge/ 6th edition, 1978
Articles written by experts
Elsevier EventLine

(The Netherlands)
DS, L

Learned Information Incorporated L

EVERYMAN'S ENCYCLOPEDIA

\section{EXPERTNET}

Current
Biographical profiles for over a thousand medical experts/

Biographical information
ExpertNet Ltd.

L

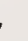


F-D-C REPORTS 1987-
Worldwide information on the health care industry/
F-D-C Reports, Incorporated

DS, L

Reports

Summary of current affairs as Facts on File, Incorporated reported by the major newspapers/

Newspapers
FACTS ON FILE

1982-
Comprehensive directory of forthcoming trade fairs, exhibitions and conferences worldwide/

Trade fair data
Internationale Arbeitsgruppe

B, DS

Current für Technologieberatung
FAMILY RESOURCES

1970
Literature concerning marriage and the family/

Journals, books, reports, nonprint materials
Full text of the federal acquisition regulations and its supplements/

National Council on Family

B, L
L
REGULATIONS

1984-
Regulations
FEDERAL INDEX 1976-1980
Information on federal government activities/

Bills, rules, speeches, documents, reports
Full text information of federal government press briefings, speeches, and interviews/

Speeches, calendar of events, interviews, transcripts
Federal Information Systems Corporation
DIALOG Information Services, Incorporated
FEDERAL ACQUISITION REGULATIONS
National Standards Association

L
L

\section{CSI FEDERAL INDEX}

FEDERAL NEWS SERVICE 1991-
Full text of the FEDERAL REGISTER/

FEDERAL REGISTER
DIALOG Information Services, Incorporated
L
FEDERAL REGISTER 1988-
FEDERAL REGISTER 


FEDERAL RESEARCH IN
PROGRESS
Current

FEDERAL RESEARCH IN

Current
Information about ongoing federally-funded research projects

in the fields of physical sciences,

engineering and life sciences/
National Technical Information L

Service (NTIS)

Research summaries

FEDREG

1977-
Federal government activities reported in the FEDERAL REGISTER/

Regulations, notices, rules
National Standards Association

B, L
FEDERAL REGISTER ABSTRACTS
FHGPUBLICA

1980-
References to publications of the Fraunhofer Society Institute in the areas of microelectronics, sensor technology, automated production, and building materials/

Books, journals, conferences, reports, bibliographies
Information Center for Regional STN Planning and Building Construction of the Fraunhofer Society

FINANCIAL TIMES COMPANY
ABSTRACTS
March 1982-

FINANCIAL

March 1982-
Company information abstracted from the London and International editions of the FINANCIAL TIMES newspapers/

Newspaper

FINANCIAL TIMES
Newspaper

Describes industry and market research reports and studies commercially available from U.S. and non-U.S. publishers/

Surveys
D-S Production Ltd. (U.K.) DS, L

D-S Production Ltd. (U.K.)

(n)

DS, L

Financial Times Business

\author{
Information Ltd. (U.K.)
}

\begin{abstract}
Complete text of all articles published in the London and International edition of the FINANCIAL TIMES newspaper/

1986-
\end{abstract}

\section{FINDEX REPORTS AND STUDIES \\ 1972-}


FINDS (FACILITIES INDEX

DATA SYSTEM)

Current
Information on more then 450,000 hazardous waste sites/
U.S. Environmental Protection

I

Directory information

FINE CHEMICALS DATABASE Current
Product information for chemical manufacturing and distribution companies in North America and Europe/

Catalogs, questionnaires, product information supplied by organizations
Chemron, Incorporated

L

\section{Agency}

Information on organizations which comprise the financial services industry and on the products and services they offer/

Journals, newspapers, newsletters, case histories

\section{Bank Marketing Association B, L}

INFORMATION SERVICE 1982-
Reports, books, journal articles and audiovisual materials in the collection of the Fire Research Information Services at NIST/
Fire Research Information

F
Research Laboratory, National

Institute of Standards and Technology (NIST)

Reports, books, journals, audiovisuals

\section{Mid 1981-}

Profiles of French companies which export or import products/
Association Telexport (France) DS

Current

Business data

\section{FLIGHTLINE 1988-}

Full text of all aspects of the international aerospace industry/

Journals
Reed Business Pub. Ltd. (U.K.) DS

FLIGHT INTERNATIONAL, AIRLINE BUSINESS

\section{FLUIDEX}

1974
International coverage of the literature of fluid engineering/

Journals, books, proceedings, reports, standards, patents
British Hydromechanics Research Association (BHRA)

Various Abstract Sources
L 
DATA BASE AND DATES COVERED
DESCRIPTION/ PRINCIPAL SOURCES
PRODUCER AND

HARD COPY COUNTERPART
VENDOR AND/OR DATA BASE INQUIRIES
FOOD SCIENCE AND TECHNOLOGY ABSTRACTS (FSTA) 1969-
Literature of research and development in food science and technology/

Journals, patents, monographs
International Food Information Service (U.K.)

FOOD SCIENCE AND TECHNOLOGY ABSTRACTS
FOODS ADLIBRA
1974-
Information relating to food industry developments/

Journals
K \& M Publications, Incorporated L

FOODS ADLIBRA
FOREIGN TRADE AND ECONOMIC ABSTRACTS 1974-1990
Worldwide literature on markets, investment climates, and economic situations in all industries/

Journals, directories, reports
Economic Information Service

L of the Dutch Ministry for Economic Affairs

ECONOMIC TITLES AND ABSTRACTS
DS, L, S, STN

\section{6-}

FORENSIC SCIENCE DATABASE
Literature on the examination of evidential materials, analytical methods, and the presentation and interpretation of findings/

Journals
Central Research Establishment,

DS Home Office Forensic Science Service (U.K.)
Current, planned and research projects in the social sciences carried out in the Federal Republic of Germany, Austria and Switzerland/

Research projects

\section{FORKAT}

Current
Descriptions of research and technology development projects supported by the Federal Ministry for Research and Technology/

Projects
Der Bundesminister für

STN

Informationszentrum

STN

Forschung und Technologie

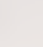

1978-
carried out in the Federal
Republic of Germany, Austria
and Switzerland/


FOUNDATION GRANTS INDEX 1973-
Information on grants by nongovernmental, nonprofit foundations/

Reports, news releases
The Foundation Center

$\mathbf{L}$ FOUNDATION NEWS
FROST \& SULLIVAN MARKET RESEARCH REPORTS 1978-
Complete coverage of Frost \& Sullivan market research reports/
Frost \& Sullivan, Incorporated

DS

\section{Reports}

FROST \& SULLIVAN POLITICAL RISK COUNTRY REPORTS Current
Assessment of the political and economic conditions in the 85 countries most important to international business/

Reports
Frost \& Sullivan, Incorporated

DS
Bibliographic database covering reports on publicly funded research projects in science and technology in the Federal Republic of Germany/
FIZ Karlsruhe (Germany)

STN
1976-
Reports
Forschungsberichte aus Technik und Naturwissenschaften
GASTROINTESTINAL ABSORPTION DATABASE 1967-1987
Literature dealing with the absorption, distribution, metabolism, or excretion of specific chemicals in laboratory animals or humans/

Reports

GENERAL PRACTITIONER 1987-
Full text of three major publications aimed at the medical practitioner/

Journals
U.S. Environmental Protection Toxic Substances

Haymarket Publishing (U.K.)

GP-GENERAL PRACTITIONER, MIMS MAGAZINE, MEDECONOMICS

$\begin{array}{ll}\text { GENETOX (MUTAGENICITY } & \text { Mutagenicity information on } \\ \text { DATABASE) } & \text { more than } 2600 \text { chemicals as } \\ \text { Current } & \text { tested against } 38 \text { biological } \\ & \text { systems/ } \\ & \text { Data }\end{array}$

U.S. Environmental Protection Agency, Office of Pesticides and Toxic Substances 
DATA BASE AND DATES

COVERED

GEOARCHIVE

1974
DESCRIPTION/

PRINCIPAL SOURCES
PRODUCER AND

HARD COPY COUNTERPART
VENDOR AND/OR DATA BASE INQUIRIES
International coverage of the literature of the geosciences/

Journals, books, proceedings, reports
Geosystems (U.K.)

L
L
Worldwide literature on geography, geology, ecology and related disciplines/
Journals, books, proceedings, reports
Geo Abstracts Ltd. (U.K.)
GEOBASE
1980-

Literature pertaining to rock mechanics, soil mechanics and engineering geology/

Journals, proceedings, reports

Worldwide coverage of the literature of the geosciences/

Journals, proceedings, symposia, theses
Pergamon Press Ltd. (U.K.)

S

GEOMECHANICS ABSTRACTS
L, S, STN

\section{GEOREF (GEOLOGICAL REFERENCE FILE) 1785-}

American Geological Institute

BIBLIOGRAPHY AND INDEX OF GEOLOGY, GEOPHYSICAL ABSTRACTS, BIBLIOGRAPHY AND INDEX OF NORTH AMERICAN GEOLOGY, BIBLIOGRAPHY OF THESIS IN GEOLOGY, BIBLIOGRAPHY AND INDEX OF GEOLOGY EXCLUSIVE OF NORTH AMERICA
GERMAN COMPANY DATABASE Listing of 350,000 German Current company profiles/
Creditreform

DS
THE GERMAN INDUSTRYMADE IN GERMANY Current
Detailed information on 18,000 major export-oriented German companies and their products/
Verlag W. Sachon GmbH and

DS 
GFI (GMELIN FORMULA INDEX) 1924-1979 (INDEX) 1924-1986 (CATALOG)
Formula index and complete catalog supplements to GMELIN HANDBOOK OF INORGANIC CHEMISTRY/

Chemical data
Gmelin Institut fur Anorganische

STN

Chemie der Max-Planck-

Gesellschaft zur Foerderung

der Wissenschaften

FORMULA INDEX FOR THE GMELIN HANDBOOK OF INORGANIC CHEMISTRY, GMELIN COMPLETE CATALOG

\section{GIDEP (GOVERNMENT- INDUSTRY DATA EXCHANGE PROGRAM) \\ 1970-}

Cooperative activity between government and industry to exchange technical data/
GIDEP Operations Center

G

Reports, engineering, metrology, failure and safety data

Index of public documents of the Federal government/

Reports, hearings, laws, bills
Government Printing Office (GPO)

B, L

MONTHLY CATALOG OF U.S. GOVERNMENT PUBLICATIONS
GRANTS

Current
Grant programs offered by government and nongovernment organizations/

Directories, bulletins
Oryx Press

L
GRANT INFORMATION SYSTEM, FACULTY ALERT BULLETIN
HARVARD BUSINESS REVIEW/ ONLINE (HBRO)

1971-
Full text coverage of HARVARD John Wiley and Sons BUSINESS REVIEW'S complete range of management subjects/

\section{HARVARD BUSINESS REVIEW}

\section{HARVARD BUSINESS} REVIEW
HAZARDLINE

Current
Regulatory, health and precautionary data on over 78,000 hazardous chemicals/
Occupational Health Services, Incorporated
B, DS, L

Chemical and toxicity data

Nonbibliographic data on toxicology of potentially hazardous chemicals/

Monographs, reports, journals
B, OHS
DATA BASE

Current
Occupational Safety and Health

DS
Administration 
HAZINF (HAZARDOUS CHEMICALS INFORMATION AND DISPOSAL)

Current edition
Information on hazardous chemicals and their disposal/
University of Alberta, Dept. of

Chemistry (Canada)
I

Chemical data

$\begin{array}{lll}\text { HEALTH (HEALTH PLANNING } & \begin{array}{l}\text { International literature of the } \\ \text { nonclinical aspects of health } \\ \text { AND ADMINISTRATION) }\end{array} & \text { National Library of Medicine } \\ \text { 1975- } & \text { Journals, monographs, symposia } & \begin{array}{l}\text { HOSPITAL LITERATURE } \\ \text { INDEX }\end{array}\end{array}$
INSTRUMENTS 1985-

Information on measurements University of Pittsburgh

B

in the health sciences/

Questionnaires, interviews, schedules, observation check-

lists, rating scales, tests

HEALTH DEVICES ALERTS 1977-
Comprehensive coverage of ECRI

L reported medical device problems, hazards, recalls, evaluations, and updates/

Journals, reports

\section{HEALTH DEVICES}

SOURCEBOOK

Current
Directory containing current address and marketing information on the North American manufacturers and distributors of more than 4000 classes of medical devices/

Mailings, interviews
ECRI

L

$\begin{aligned} & \text { HEALTH INDUSTRY RESEARCH } \\ & \text { REPORTS }\end{aligned}$
$\begin{aligned} & \text { Reports on health related } \\ & \text { companies and the health } \\ & \text { industry/ }\end{aligned}$
Reports

JA Micropublishing, Incorporated

B

\section{HEALTH PERIODICALS \\ DATABASE \\ 1988-}

Literature in the areas of health,

Information Access Company

B, DS, L

B, L, NLM

Journals 
HISTLINE (HISTORY OF MEDICINE ONLINE)

1970-

DESCRIPTION/

PRINCIPAL SOURCES

International literature on the

history of medicine/

Journals, monographs, symposia

Worldwide coverage of the literature of history and related social sciences and humanities/

Journals
HISTORICAL ABSTRACTS

1973-
PRODUCER AND

HARD COPY COUNTERPART

VENDOR AND/OR DATA

BASE INQUTRIES
National Library of Medicine

NLM
BIBLIOGRAPHY OF THE HISTORY OF MEDICINE
ABC-Clio, Incorporated

L

HISTORICAL ABSTRACTS:

PART A, MODERN HISTORY

ABSTRACTS

PART B, TWENTIETH

CENTURY ABSTRACTS

\section{HODOC}

Current
Numeric file providing physical and chemical data on organic

compounds/

Chemical data
CRC Press, Incorporated

\section{STN}

CRC HANDBOOK OF DATA

ON ORGANIC CHEMICAL

DATA

\section{HOPPENSTEDT AUSTRIA}

Current
Descriptions of over 3000 major companies in Austria/

Company data
Verlag Hoppenstedt and Company

(Germany)

OESTERREICH 2000
DS
DS

C.V. (Netherlands)

the Netherlands, Belgium, and

Luxembourg/

Company information

Various print publications

\section{HOPPENSTEDT DIRECTORY OF GERMAN COMPANIES Current}

A directory file for 36,000

German companies/

Directory data
Hoppenstedt Wirtschaftsdatenbank DS, L Gmbh

HANDBUCH DER GROSSUNTERNEHMEN, HANDBUCH DER MITTLESTAENDISCHEN UNTERNEHMEN 
HOPPENSTEDT TREUHANDANSTALT Current
Information on companies to be privatized in the new Federal States/

Directory information
Hoppenstedt Wirtschafts-

DS

OFFIZIELLES FIRMEN-

VERZEICHNIS DER TREUHANDANSTALT

\section{HSELINE}

1977-
Health and safety aspects of manufacturing industries, agriculture, engineering, mining, etc./

Reports, journals, books, proceedings, patents, standards
Health and Safety Executive (U.K.)
DS, S
Abstracts and index to more than 4000 documents from the U.S. Housing and Urban Development Administration (HUD)/
U.S. Housing and Urban

B

Policy Development

Reports

\section{ICC BRITISH COMPANY DIRECTORY \\ Current}

Directory and comprehensive information on companies in Scotland, England and Wales/

Financial data, directory information
Inter Company Comparisons Ltd. DS, L (U.K.)
Commercial and financial information on 60,000 British companies/
Inter Company Comparison Ltd. DS, L (U.K.)
FINANCIAL DATASHEETS Current

Financial data

ICC INTERNATIONAL ANNUAL REPORTS

Current
Full text of the annual reports and accounts produced by the leading 500 European quoted companies and all U.K. quoted companies/

Annual reports
ICC Online Ltd. (U.K.)

L

\section{ICC INTERNATIONAL BUSINESS RESEARCH Current}

Full text information from bank and brokerage reports, annual reports and the "key note" series of marketing information reports/
ANNUAL REPORTS AND ACCOUNTS

ICC Stockbroker Research Ltd., L 
ICC KEYNOTES MARKET

ANALYSIS

Current

Detailed market information on 175 U.K. industry sectors/

ICC Database (U.K.)

DS

Reports

Detailed company and industry analysis from stockbrokers/

\section{RESEARCH}

ICC STOCKBROKERS

Current

Reports

ICIS-LOR OIL AND CHEMICAL REPORTS

Current

Pricing and background infor-

mation for over 40 crude and

ICIS-LOR Group Ltd. (U.K.)

DS

25 petroleum products/

Reports

ICONDA (INTERNATIONAL CONSTRUCTION DATABASE) 1976-
Worldwide literature on all fields of building construction, construction engineering, architecture and town planning/

Journals, reports, books, proceedings, non-conventional literature
International Council for Building Research, Studies

S, STN and Documentation
DS

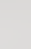

(n)


DATA BASE AND DATES COVERED
DESCRIPTION/

PRINCIPAL SOURCES
PRODUCER AND

HARD COPY COUNTERPART
VENDOR AND/OR DATA

BASE INQUIRIES
IMAGING ABSTRACTS

1977-
Worldwide literature on all aspects of photography/

Journals, patents
Royal Photographic Society

S

Data about cells of immunological interest, such as hybridomas,

CERDIC (France)

DS

T-cell clones, and monoclonal antibodies/

Catalogs, patents, journals, hybridoma collections
IMSWORLD Pubs. Ltd.

DS international health care news/

DATABASE

1985-

Journals, press releases,

conferences, interviews

INDUSTRY DATA SOURCES

1979-1990
Citations to market research reports, investment studies and statistical summaries/

Financial and economic reports, forecasts, directories, proceedings
Information Access Company

DS, L

\section{DIRECTORY OF INDUSTRY DATA SOURCES}

U.S. Environmental Protection

I

Summaries of EPA regulations on particular industries and chemicals/

\section{Agency}

INDUSTRY FIL
SYSTEM (IFIS)

1985-

Regulations

INFODATA

1976-
Bibliographic database containing the relevant German and international literature in the field of information science/

Journals, books, reports, proceedings
Gesellschaft für Mathematik und STN Datenverarbeitung $\mathrm{mbH}$ (Germany)

(1)

\begin{tabular}{lll}
$\begin{array}{l}\text { IMMUNOCLONE DATABASE } \\
\text { 1986- }\end{array}$ & $\begin{array}{l}\text { Data about cells of immunologi- } \\
\text { cal interest, such as hybridomas, } \\
\text { T-cell clones, and monoclonal } \\
\text { antibodies/ }\end{array}$ & CERDIC (France) \\
& $\begin{array}{l}\text { Catalogs, patents, journals, } \\
\text { hybridoma collections }\end{array}$ & DS \\
\hline $\begin{array}{l}\text { IMS MARKETLETTER } \\
\text { DATABASE }\end{array}$ & $\begin{array}{l}\text { Full text information of the } \\
\text { international health care news/ }\end{array}$ & IMSWORLD Pubs. Ltd.
\end{tabular}


INFOR (INFORMATION ABOUT RESEARCH IN THE FEDERAL STATE OF BADENWUERTTEMBERG)

1987-
Information in German concerning humanities, physical sciences, life sciences and engineering/
Ministerium für Wissenschaft und Kunst (Germany)

STN

L

Worldwide coverage of information science literature/
IFI/Plenum Data Company ABSTRACTS

1966-
Reports, proceedings, journals, patents, books
INFORMATION SCIENCE ABSTRACTS
Profiles of 180,000 Belgium companies/
INFOTRADE (Belgium) COMPANY DATABASE Current
Reports, catalogs, journals, questionnaires, interviews

\begin{tabular}{|c|c|c|c|}
\hline $\begin{array}{l}\text { INPADOC } \\
\text { Current }\end{array}$ & $\begin{array}{l}\text { Listing of worldwide patents } \\
\text { in all areas of technology/ } \\
\text { Patents }\end{array}$ & $\begin{array}{l}\text { International Patent } \\
\text { Documentation Center } \\
\text { INPADOC PATENT GAZETTE }\end{array}$ & $\mathrm{L}, \mathrm{S}, \mathrm{STN}$ \\
\hline $\begin{array}{l}\text { INSIDER TRADING MONITOR } \\
\text { 1984- }\end{array}$ & $\begin{array}{l}\text { Transaction details of all insider } \\
\text { trading filings received by the } \\
\text { SEC/ } \\
\text { SEC financial data }\end{array}$ & - & $\mathbf{L}$ \\
\hline $\begin{array}{l}\text { INSPEC } \\
1969\end{array}$ & $\begin{array}{l}\text { Worldwide coverage of the litera- } \\
\text { ture in physics, electrotechnology, } \\
\text { computer and control engineering, } \\
\text { and information technology/ } \\
\text { Journals, technical reports, theses, } \\
\text { proceedings, books, patents }\end{array}$ & $\begin{array}{l}\text { PHYSICS ABSTRACTS } \\
\text { (INSPEC A), ELECTRICAL } \\
\text { AND ELECTRONIC } \\
\text { ABSTRACTS (INSPEC B), } \\
\text { COMPUTER AND CONTROL } \\
\text { ABSTRACTS (INSPEC C), } \\
\text { INFORMATION TECHNOLOGY } \\
\text { (INSPEC D) }\end{array}$ & B, DS, L, S, STN * \\
\hline
\end{tabular}

Available also in CD-ROM format from producer from 1988- 
DATA BASE AND DATES

COVERED
DESCRIPTION/

PRINCIPAL SOURCES
PRODUCER AND

HARD COPY COUNTERPART
VENDOR AND/OR DATA

BASE INQUIRIES

\section{INSURANCE ABSTRACTS 1979-1984}

Information on life and health insurance as well as risk management, property and liability insurance/

Journals
University Microfilms

L

LIFE INSURANCE INDEX, PROPERTY AND LIABILITY INSURANCE INDEX

\section{INSURANCE PERIODICALS INDEX \\ Literature of the insurance business/} 1984-
NILS Publishing Company/

L

Journals

\section{INTERNATIONAL PETROLEUM ABSTRACTS \\ 1984}

International literature on such areas as petroleum refining and products, geology, oilfield exploration and geophysics/

Journals
John Wiley and Sons

S

\section{INTERNATIONAL PHARMA- CEUTICAL ABSTRACTS (IPA) 1970- \\ INTERNATIONAL PLASTICS SELECTOR MATERIALS DATABASE \\ 1977-}

International literature on all phases of drugs and pharmaceutical practices/

Journals, reports
American Society of Hospital
Pharmacists
INTERNATIONAL PHARMA- CEUTICAL ABSTRACTS

B, DS, L
Manufacturer supplied data on mechanical, thermal, electrical and processing properties, flammability and uses for more than 12,000 commercial plastics/

Manufacturer specifications

\begin{abstract}
INTERNATIONAL REVIEW OF PUBLICATIONS IN SOCIOLOGY 1980-
\end{abstract}

Citations to book reviews and detailed abstracts of books in sociology and related disciplines/

Books
International Plastics Selector,

STN
Sociological Abstracts, Incorporated
B, L

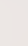


INVESTOR'S DAILY

1986-
Bibliographic database with abstracts to INVESTOR'S

DAILY, a financial newspaper/

Newspaper

Risk assessment database providing information on levels of exposure to hazardous chemicals/

Chemical Information Systems,

I

B

Chemical data, regulations,

statutes

Information on 6500 IR spectra/

EPA/Boris Kidric Institute

SYSTEMS)

(Yugoslavia)

Current

Spectral data

ISHOW (INFORMATION SYSTEM FOR HAZARDOUS ORGANICS

IN WATER)

1970-
U.S. Environmental Protection Agency, Office of Pesticides and Toxic Substances

\section{I}

Physical property data for chemicals

Property data
ISIS SOFTWARE DATABASE Current
Descriptions in German of computer programs for industryspecific and industry-wide commercial, technical and scientific applications available in Germany, Austria and Switzerland/

Reports

Worldwide literature in the fields of mechanical engineering and engineering management/

Journals

Multidisciplinary conference literature/

Proceedings
Nomina Gesellschaft fur DS

Wirtschafts- und verwaltungs-

register mbH (Germany)
ISMEC

1973-
ISTP SEARCH

1982-
Data Courier, Incorporated

B, L

ISMEC BULLETIN

Institute for Scientific Information S

INDEX TO SCIENTIFIC AND TECHNICAL PROCEEDINGS 
DATA BASE AND DATES COVERED

JANAF

1959-
DESCRIPTION/

PRINCIPAL SOURCES
PRODUCER AND

HARD COPY COUNTERPART
VENDOR AND/OR DATA

BASE INQUIRIES
Critically evaluated chemical thermodynamic properties of inorganic and organic substances/

Property data
National Institute of Standards and Technology (NIST)

STN

\section{JANAF THERMOCHEMICAL}

TABLES

International perspective on defense related topics/

Jane's Information Group (U.K.)

L

JANE'S DEFENSE AND AEROSPACE NEWS/ANAL YSIS 1982-
JANE'S DEFENSE WEEKLY

Kyodo News International,

L

General and business news from Japan and international news that relates to Japan/ Incorporated

\section{PLUS}

1984

Newswires

Business and technical news from Japan/

Newspapers, journals, news releases, government papers
Comline International Corporation DS (Japan)
JAPAN
Literature on the business, technology, and science of Japan/

Journals
SCAN C2C

L, S
JAPAN TECHNOLOGY-JTEC 1985-

\section{C2C ABSTRACTS: JAPAN \\ C2C CURRENTS: JAPAN}

\section{JAPANESE GOVERNMENT AND PUBLIC RESEARCH IN PROGRESS}

Current
Current and recently completed research by public research organizations in Japan/
The Japan Information Center of Science and Technology (JCST)
STN

(n)

Questionnaires

$\begin{array}{lll}\text { JAPINFO } & \begin{array}{l}\text { English abstracts of the scientific } \\ \text { and technical grey literature } \\ \text { published in Japan/ }\end{array} & \begin{array}{l}\text { EUROBROKERS SARL } \\ \text { (Luxembourg) }\end{array} \\ \begin{array}{ll}\text { J987- } & \text { Journals, proceedings }\end{array}\end{array}$

\section{JAPIO}

1976-
Japanese patent data for over $1,000,000$ Japanese patent records in English translation/

Patents
Japan Patent Information
Organization

PATENT ABSTRACTS

OF JAPAN 
JERUSALEM POST ELECTRONIC Full text of the Jerusalem Post, EDITION

1988current events, business, and a daily newspaper which covers politics/

Newspaper

Literature from Japan on all fields of science, technology and medicine/

Journals, reports
THE JERUSALEM POST

DS
THE JERUSALEM POST

JCST
$1985-$

Full text of the world's leading daily newspaper for international trade and transportation/

Newspaper

Important new clinical studies published in a core group of 19 journals/

Journals
The Journal of Commerce,

L Incorporated

JOURNAL OF COMMERCE

Medical Publishing Group, B Massachusetts Medical Society
July 1987-
Japan Information Center of
JOURNAL OF COMMERCE

1988-
KIRK-OTHMER ENCYCLOPEDIA OF CHEMICAL TECHNOLOGY Current
Third edition of Kirk-Othmer including index entries, references, and tables/

Encyclopedia
John Wiley and Sons

B, DS, L

KIRK-OTHMER ENCYCLOPEDIA OF CHEMICAL TECHNOLOGY

KKF

1973-
International literature on plastics and polymers/

Journals, books, proceedings standards, reports
Deutsches Kunststoff-Institut

STN
Full text financial news/ NEWS

Current
Knight-Ridder Financial Information
L

Reports, market data, quotes

KNOWLEDGE INDUSTRY PUBLICATIONS DATABASE Current
Descriptions of publicly available databases/

Databases
Knowledge Industry Publications, Incorporated
B

DATA BASE DIRECTORY 
DATA BASE AND DATES

COVERED
DESCRIPTION/

PRINCIPAL SOURCES
PRODUCER AND

HARD COPY COUNTERPART
VENDOR AND/OR DATA

BASE INQUIRIES
KOMPASS ASIA/PACIFIC

Current
Directory of approximately

167,000 companies in Asian and Pacific areas/

Directory information
Kompass International Manage-

ment Corporation (Switzerland)
L
Directory file of 210,000

European companies/

Directory information
KOMPASS EUROPE

Current
Comprehensive directory of

Israeli industrial and commercial

firms/
Reed Information Services Ltd. (U.K.)
L

\section{KOMPASS REGISTER OF INDUSTRY AND COMMERCE OF ISRAEL \\ Current}

Business data supplied by firms
Kompass Israel Ltd. (Israel) DS 


\section{LABORLAW}

Coverage varies
Index to U.S. federal, state, and administrative agency decisions pertaining to labor relations/

Decisions
Bureau of-National Affairs

L

\author{
LABOR RELATIONS, LABOR \\ ARBITRATION REPORTS, \\ FAIR EMPLOYMENT PRAC- \\ TICE CASES, WAGE AND \\ HOUR CASES, OCCUPATION- \\ AL SAFETY AND HEALTH \\ CASES, MINE SAFETY AND \\ HEALTH CASES
}

\section{LC (LIBRARY OF CONGRESS) MARC 1968-}

Listing of monographic works of the Library of Congress/.
U.S. Library of Congress

L

Monographs

LEGAL RESOURCE INDEX (LRI) 1980-
Comprehensive index to legal and law related literature/

Journals, newspapers
Information Access Company

B, L

LEGAL RESOURCE INDEX (COM), CURRENT LAW INDEX

LEGAL STATUS

Late 1960's-
Listing of different types of actions which can affect the legal status of a patent document after it is published and granted/

Patent actions
International Patent Documentation S Center
Full text of the law from the various courts in the United States and in the United Kingdom; regulations/

Case law, slip opinions, slip laws, regulations
Mead Data Central

M 1890-(varies)
Online catalog listing of the books, journals, proceedings, and reports which are in the National Institute of Standards and Technology's (NIST) Research Information Center (RIC) Collection/

Books, journals, proceedings, reports
Caselaw Publications, FEDERAL REGISTER, CODE OF FEDERAL REGULATIONS, etc.

National Institute of Standards SI and Technology (NIST), Research Information Center (RIC) 


$\begin{array}{lll}\begin{array}{l}\text { LINGUISTICS AND LANGUAGE } \\ \text { BEHAVIOR ABSTRACTS }\end{array} & \begin{array}{l}\text { Worldwide literature on language } \\ \text { and language behavior/ }\end{array} & \begin{array}{l}\text { Sociological Abstracts, } \\ \text { Incorporated }\end{array} \\ & \text { Journals, monographs } & \text { LINGUISTICS AND } \\ & & \text { LANGUAGE BEHAVIOR } \\ & \text { ABSTRACTS, READING } \\ & \text { ABSTRACTS }\end{array}$

LISA (LIBRARY AND INFORMATION SCIENCE ABSTRACTS) 1969
Worldwide coverage of the literature of library and information science/

Journals, reports, monographs, proceedings
Learned Information (U.K.)

B, L, S SCIENCE ABSTRACTS

\section{LITALERT}

1970
Information related to unresolved or unreported cases against patents and trademarks filed in the U.S. District Courts/
INFAX Corporation

$S$

Cases

\section{LMS DRUG ALERTS ONLINE 1983-(varies)}

Summaries of important papers from the international literature on drugs, drug therapy, and adverse drug experiences/

Journals
ADIS International Ltd.

DS
M\&A FILINGS

1985-
Detailed abstracts of every original and amended merger and acquisition document released by the SEC/

Merger and acquisition filings
M\&A Filings, Charles E. Simon L and Company

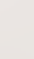

\begin{tabular}{llll}
$\begin{array}{l}\text { MCGRAW-HILL PUBLICATIONS } \\
\text { ONLINE } \\
\text { 1985- }\end{array}$ & $\begin{array}{l}\text { Full text of McGraw-Hill's } \\
\text { leading magazines/ }\end{array}$ & McGraw-Hill, Incorporated & L \\
& Magazines & McGraw-Hill Publications & \\
\hline $\begin{array}{l}\text { MAGAZINE ASAP } \\
\text { 1983- }\end{array}$ & $\begin{array}{l}\text { Full text of more than 100 fre- } \\
\text { quently cited popular journals/ }\end{array}$ & Information Access Company & B, L \\
& Journals & &
\end{tabular}


MAGAZINE INDEX 1959-
Extensive coverage of the literature of current affairs, general news, and information/

Magazines
Information Access Company $\quad$ B, DS, L

MAGAZINE INDEX (COM)
L
MAGILL'S SURVEY OF CINEMA 1902-
Full text articles on more than 1800 notable films from silent films to the present/

Film data
Salem Press, Incorporated

MAGILL'S CINEMA ANNUAL, MAGILL'S SURVEY OF CINEMA: FOREIGN LANGUAGE FILMS

\section{MANAGEMENT CONTENTS} September 1974-
Extensive coverage of the litera- Information Access Company ture of business and management/
B, DS, L

Journals, proceedings, transactions, MANAGEMENT CONTENTS books, courses

Management information on DRKW-Arbeitsgruppe

DS

MANAGEMENT INFO WIRTSCHAFT 1987- banking, finance, and the economy des Informationsring

principally in the German-speak- Kreditwirtschaft

ing countries/

Journals
MARQUIS WHO'S WHO 1982-
Detailed biographical information Marquis Who's Who Incorporated L on outstanding professionals in all fields/

Biographical data

Full text database on the properties of drugs and medicines/

Drug data
MARQUIS WHO'S WHO Series
The Pharmaceutical Society of Great Britain

MARTINDALE, THE EXTRA PHARMACOPOEIA
MARTINDALE ONLINE Current edition
DS, L

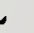

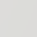


MATH

1972-
Worldwide publications in pure and applied mathematics/

Journals, proceedings, books
Fachinformationszentrum

Karlsruhe

ZENTRALBLATT FÜR MATHEMATIK
MATHEMATICAL DIDACTICS 1976-
Worldwide literature in mathematical education and related fields/

Journals, reports, books, proceedings, non-conventional literature
FIZ Karlsruhe (Germany)

STN
STN 
MENTAL HEALTH ABSTRACTS 1969-
International literature on all aspects of mental health \& mental illness/

Journals, reports, proceedings, books
IFI/Plenum Data Company

L

Buros Institute of Mental

B
Factual information, critical reviews and reliability - validity information on English language tests covered in the MENTAL MEASUREMENTS YEARBOOK/

Factual information
Measurements, University

of Nebraska
Descriptions of substances of chemical, biological, pharmaceutical and commercial interests/

Monographs

International literature of metallurgy/

Materials Information

DS, L, S, STN
Merck \& Co., Incorporated

B, I, L
MERCK INDEX

\section{METADEX (METALS ABSTRACTS/ALLOYS INDEX)} 1966-
Eighth MENTAL MEASUREMENTS YEARBOOK

MERCK
Current

Journals, proceedings, books,

METALS ABSTRACTS INDEX, reports ALLOYS INDEX, REVIEW OF METAL LITERATURE

METEOROLOGICAL AND GEOASTROPHYSICAL ABSTRACTS (MGA)

1972-
Worldwide literature of meteorological and geoastrophysical research/

Journals, monographs, proceedings
American Meteorological Society

L

\section{METEOROLOGICAL AND \\ GEOASTROPHYSICAL ABSTRACTS}

MICRO SOFTWARE DIRECTORY Current
Business and professional microcomputer software products currently available in the United States/

Ads, press releases, journals, books
Online, Incorporated
MICROCOMPUTER INDEX 1981-
Literature on the use of microcomputers in business and in the home/
Learned Information, Incorporated

L

Journals MICROCOMPUTER INDEX 
MICROCOMPUTER SOFTWARE

GUIDE

Current
Information on microcomputer software programs and hardware systems available or produced in the United States/

Press releases, books, periodicals
R. R. Bowker Company

L
THE SOFTWARE ENCYCLOPEDIA
MICROSEARCH
1982-
Coverage of reviews and instructional articles from microcomputer-related literature/

Journals
Information, Incorporated

\section{$S$}

U.S. Dept. of Defense and

STN and physical properties for

metallic aerospace materials/

Property data

\section{MIL-HDBK- 5 \\ 1987-1989}

Comprehensive information covering modern language and literature/

Journals, books

Information in German on preservation of historical monuments/

Journals, books, proceedings, reports, questionnaires, nonconventional literature
Modern Language Association of America

L

\section{MONUDOC}

1980
Information Center for Regional

Planning and Building Construc-

STN
Financial and business information on more than 3900 major corporations and institutions in 100 countries/

Financial data
Moody's Investor's Service,

L

\section{INTERNATIONAL}

1983
Incorporated

\section{MOODY'S INTERNATIONAL} NEWS REPORTS
MOODY'S CORPORATE NEWSU.S. 1983-
Financial and business information on 13,000 publicly held U.S. corporations/

Financial data
Moody's Investor's Service, Incorporated

Various Moody's News Reports
L 
MOODY'S CORPORATE PROFILES

Current
Descriptive and financial information on the most important publicly held U.S. companies/
Moody's Investors Service, Incorporated
L

Financial data

Literature on all aspects of automobile engineering /
The Motor Industry Research Association (U.K.)
DS

\section{MOTOR INDUSTRY RESEARCH ASSOCIATION 1980-}

Newspapers, journals, proceedings, standards

\section{MPDSEARCH}

Current
Guide to computerized materials property databases worldwide/

Databases
Materials Property Data Network, STN Incorporated

J. T. Baker Incorporated/Mallin

I

Safety data on 1500 chemicals/

Current

\section{Chemical data}

\section{MSDS-CCOHS}

Current
Occupational safety and health data for over 65,000 Canadian and U.S. products used in Canadian workplaces/

Material safety data sheets
Canadian Centre for Occupational STN Health and Safety
International coverage of the music literature/

Books, journals, reviews, dissertations, catalogs
Repertoire International de Literature Musicale

\section{MUSIC LITERATURE INTERNATIONAL}

MUSIC LITERATURE

INTERNATIONAL

1972-
National Rehabilitation

B

\section{Literature on the rehabilitation of the physically or mentally disabled/ \\ ILITATION INFORMATION CENTER)}

1956-
Information Center, Catholic

University of America
L

Reports, books, audiovisuals, microfiche 
NASA/RECON

1962-
Worldwide literature in the fields of engineering, geosciences, mathematical and computer sciences, chemistry and materials, aeronautics and physics/

Reports, books, journals, patents
U.S. National Aeronautics and Space Administration (NASA)
NASA
SCIENTIFIC AND TECHNICAL AEROSPACE REPORTS, INTERNATIONAL AEROSPACE ABSTRACTS
NATIONAL ENVIRONMENTAL DATA REFERRAL SERVICE Current
Catalog and index to nonbibliographic environmental data/

Data compilations, manuals, data centers, published and unpublished data files
National Oceanic and Atmospheric B Administration (NOAA)
NATIONAL NEWSPAPER INDEX 1979
Index to articles in major newspapers/

Newspapers
Information Access Company

B, L

NATIONAL NEWSPAPER INDEX (COM)

NCJRS (NATIONAL CRIMINAL JUSTICE REFERENCE SERVICE) 1972-
International literature of criminal National Criminal Justice justice and law enforcement/ Reference Service

L

Journals, reports

NEW YORK TIMES

1969-
News and editorial information from the NEW YORK TIMES plus other newspapers and magazines/

Journals, newspapers
New York Times Company

$\mathbf{M}$
NEWSEARCH

Current
Daily update of MAGAZINE INDEX, NATIONAL NEWSPAPER INDEX, LEGAL RESOURCE INDEX, TRADE AND INDUSTRY INDEX and MANAGEMENT CONTENTS/

Newspapers, journals
NEW YORK TIMES
Information Access Company $\quad$ B, L

$B$ 
NEWSPAPER ABSTRACTS 1984-1988
Index to articles from 19 major regional, national, and international newspapers/
University Microfilms International L

Various newspapers
Newspapers

Complete business and general reference information/

ABSTRACTS 1988-
Data Courier, Incorporated

$\mathbf{L}$

Newspapers, periodicals

NEWSWIRE ASAP

Dates vary
Full text of newswire stories/
Information Access Company

L

Newswires

Full text retrieval service for

Mead Data Central

$\mathbf{M}$

NEXIS
1975-(varies)

news, scientific, technical, business, popular literature and wire services/

Magazines, newswires, newspapers, newsletters

Various Publications

NISTFLUIDS

1986
Calculational program that determines the thermophysical and transport properties of twelve organic fluids/

Property data
National Institute of Standards and Technology (NIST)

NBS TECHNICAL NOTE 1097

\section{NISTTHERMO}

Current
Recommended values for selected thermodynamic properties for inorganic and simple organic substances/

Property values
National Institute of Standards and Technology (NIST)/Texas A\&M University, Thermodynamics Research Center

NIST TABLES OF CHEMICAL THERMODYNAMIC PROPERTIES/DATA FILES OF THE THERMODYNAMIC RESEARCH CENTER
RESONANCE LITERATURE SYSTEM)

1964-1984
Worldwide literature on nuclear magnetic resonance/
Journals
NUCLEAR MAGNETIC RESONANCE LITERATURE ABSTRACTS AND INDEX 
NONFERROUS METALS

ABSTRACTS

1961-1983
International literature on the nonferrous metals industry and the production and use of nonferrous metals/

Journals, books, pamphlets, reports, standards

Listing of condensed versions of NASA tech briefs/

Tech briefs

Government-sponsored research and development including sciences, technology, and regulatory matters/

Technical reports
BNF Metals Technology

Centre

L

$\begin{array}{llll}\text { NTB (NASA TECH BRIEF) } & \begin{array}{l}\text { Listing of condensed versions } \\ \text { of NASA tech briefs/ }\end{array} & \begin{array}{l}\text { U.S. National Aeronautics } \\ \text { and Space Administration (NASA) }\end{array}\end{array}$

BNF NONFERROUS METALS ABSTRACTS

NASA TECH BRIEFS

National Technical Information

B, DS, L*, S, STN

1964 Service

WEEKLY GOVERNMENT

REPORTS, GOVERNMENT

REPORTS ANNOUNCEMENTS

\section{NUCLEAR SCIENCE \\ ABSTRACTS \\ 1948-1976}

Comprehensive international information on nuclear science technology /

Journals, reports, proceedings, books, patents, thesis
Department of Energy, Office

L of Scientific and Technical

Information

\section{NUCLEAR SCIENCE ABSTRACTS}

\section{NURSING AND ALLIED \\ HEALTH \\ 1983-}

Broad coverage of the literature of nursing, allied health and health care/

Journals
Cumulative Index to Nursing and Allied Health Literature Corporation

\section{CUMULATIVE INDEX TO NURSING AND ALLIED HEALTH LITERATURE}

\section{OAG ELECTRONIC EDITION} Current
Flight information and fares for North American travel/
Official Airline Guide

DS, L, S

Travel information

OCCUPATIONAL SAFETY AND HEALTH

1973-
Literature on all aspects of the safety and health field/

Journals, reports
National Institute for Occupational L, S Safety and Health (NIOSH)
B, DS, L 
OCLC

1968-
Descriptive information on books and serials added to the Library

of Congress and over 10,000 other

libraries throughout the country/

Books, serials
OCLC, Incorporated

O
Nonbibliographic data on oil and hazardous materials/
U.S. Environmental Protection

Agency (EPA), Office of Solid

Waste and Emergency Response
HAZARDOUS MATERIALS TECHNICAL ASSISTANCE

DATA SYSTEM)

Current
Data
$1 \times 1$ GERMAN BUYER'S GUIDE

Current
Information on 57,500 German companies and their products/
Deutscher Addressbuchverlag

DS
Gmbh (Germany)
I

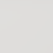


International literature of the pulp, paper, and board manufacturing industries/

Journals, patents, proceedings
Institute of Paper Chemistry

L
July 1968-
Full text of various newspapers/

1985-
Newspapers

Worldwide scientific and technical literature/

Journals, proceedings, theses, reports, books, patents

\section{ABSTRACT BULLETIN OF THE INSTITUTE OF PAPER CHEMISTRY}

BASE INQUIRIES

\section{PASCAL}

1973-
Utility patents, reissue patents and defensive publications issued by the U.S. Patent and Trademark Office/
DIALOG Information Services, Incorporated

Various newspapers
Institut de l' Information

Scientifique

BIBLIOGRAPHIE INTERNATIONALE
PATDATA (PATS)

1975-

Patents

BRS

B
L

L

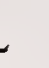


PETERSON'S COLLEGE

DATABASE

Current year
Comprehensive file of degreegranting, post-secondary colleges and universities in the United

States and Canada/

Admission's Office data
Peterson's Guides

B, L
GUIDE TO FOUR-YEAR
COLLEGES, GUIDE TO
TWO-YEAR COLLEGES

Peterson's Guides

$\mathbf{L}$
PETERSON'S GRADLINE

Current
Information on graduate and professional programs offered by accredited colleges and universities in the United States and Canada/

Survey data
PETERSON'S ANNUAL GUIDES/GRADUATE STUDY
PHARMA MARKETING SERVICE 1987-
International marketing information for the pharmaceutical industry/

Newspapers, journals, press releases
Aerzte Zeitung Verlags-Gmbh

DS
Names and addresses of over 7,000 pharmaceutical companies in Europe and the Americas and 2,400 animal health companies worldwide/

Directories
V \& O Publications Ltd.

(U.K.)

PHARMA MARKETING NEWS
PHARMACONTACTS

Current
Pharmaceutical products under development worldwide/

Drug information
PHARMAPROJECTS Current
Drug-related literature with emphasis on adverse drug effects/
B, DS

Various pharmaceutical and agrochemical directories

PHARMLINE

1978-

Journals

PHILOSOPHER'S INDEX 1940-
Comprehensive information on all aspects of philosophy and related fields/

Journals, books
Pharmaprojects,

V \& O Publications Ltd. (U.K.)

PHARMAPROJECTS
Regional Drug Information

Service (U.K.)
Philosophy Documentation

Center

B, DS, L, STN

DS 


\section{PHIND}

1986-
Full text information on product developments, markets and regulatory affairs of importance to the international pharmaceutical, medical device, veterinary and agrochemical industries/

Newsletters
PJB Publications Ltd. (U.K.) $\quad$ B, DS, L

Various pharmaceutical and agrochemical newsletters
PHYSICS BRIEFS

1979-
Worldwide literature on all fields of physics and related topics/

Journals, proceedings, books. reports
Fachinformationszentrum (Germany)

PHYSICS BRIEFS/

PHYSIKALISCHE BERICHTE
STN

Biologische Bundesanstalt für

STN

\section{PHYTOMED}

1965-
Worldwide literature, mostly in German, in the field of plant sciences/

Journals, books, proceedings, theses
University of Oklahoma,

I

the biological effects of the application of organic chemicals to terrestrial plants/

Journals, data
Department of Botany and

Microbiology

Current

Compilation of manifests of vessels loading international cargo at 62 U.S. continental seaports/

Loading data
PIERS, Journal of Commerce

L

\section{PIERS EXPORT
Current 3 months}

Compilation of manifests of vessels discharging international

PIERS, Journal of Commerce

L cargo at 62 U.S. continental seaports/

Discharging data 
PIRA

1975-
Worldwide literature in the fields of paper and board manufacturing, printing, packaging, etc./

Journals, books, pamphlets, standards
The Research Association for and Packaging Industries (PIRA) (U.K.)

PAPER AND BOARD ABSTRACTS, PRINTING ABSTRACTS, PACKAGING ABSTRACTS, MANAGEMENT AND MARKETING ABSTRACTS

\section{PLASNEWS} 1987-
Company activities and commodities availabilities in the plastics industry /

Press conferences, news releases, trade shows, interviews, surveys
PLASPEC
STN

$\begin{array}{ll}\text { PLASPEC (PLASTIC MATERIALS } & \begin{array}{l}\text { Numeric database containing } \\ \text { information on commercially } \\ \text { SELECTION DATABASE) }\end{array} \\ \begin{array}{ll}\text { available plastics materials } \\ \text { including thermoplastic, ther- } \\ \text { moset and elastomer products/ }\end{array} \\ & \text { Technical specifications }\end{array}$

PLASPEC (PLASTIC MATERIALS Numeric database containing SELECTION DATABASE)

specifications

PNI (PHARMACEUTICAL NEWS INDEX)

1975-
Current news about pharmaceuticals, cosmetics, medical devices/

Newsletters
Data Courier, Incorporated

B, L, S

FDC REPORTS, DRUG RESEARCH REPORTS, PMA NEWSLETTER, WASHINGTON DRUG AND DEVICE LETTER, etc.

POLLUTION ABSTRACTS 1970-
Worldwide coverage of the literature of pollution and related topics/

Journals, technical reports, newspapers, government publications
Cambridge Scientific Abstracts

DS, L

\section{POLLUTION ABSTRACTS}

Comprehensive treatise of polymer science and engineering/

Encyclopedia
John Wiley and Sons, Incorporated L

ENCYCLOPEDIA OF POLYMER SCIENCE AND ENGINEERING 
DATA BASE AND DATES

COVERED

POPLINE

1970
DESCRIPTION/

PRINCIPAL SOURCES
PRODUCER AND

HARD COPY COUNTERPART
VENDOR AND/OR DATA

BASE INQUIRIES
Literature in all areas of family planning, fertility control, population and reproduction/

Journals, monographs, reports, unpublished works
Population Information Program, NLM Johns Hopkins University/

Center for Population and

Family Health Library, Columbia

University

\section{POPULAR
ONLINE
1984-}

Latest popular U.S. periodical

literature/

Periodicals
Data Base Communications

Corporation

B

POPULAR MAGAZINE

REVIEW

\section{POPULATION BIBLIOGRAPHY 1966-1984}

International coverage of population topics emphasizing the social science aspect/

Journals, monographs, reports, unpublished documents
Carolina Population Center,

L at Chapel Hill University of North Carolina

at Chapel Hill

.

\section{POWER}

1950-
Catalog of books in the Department of Energy (DOE) Library/
U.S. Department of Energy

(DOE), Library
S

Books, proceedings

\section{PR NEWSWIRE \\ 1987-}

Complete text of news releases, mainly business and financial/
PR Newswire Association, Incorporated
L

News releases

\section{PSYCHINFO 1967-}

\section{PTS AEROSPACE/DEFENSE MARKETS AND TECHNOLOGY 1982-}

Worldwide literature of psych- American Psychological ology and the behavioral sciences/ Association

Journal, reports, monographs
PSYCHOLOGICAL ABSTRACTS
DS, L
Index to defense industry information/

Predicasts, Incorporated B, DS, L

Journals, newspapers, reports, press releases, contract awards 
PTS ANNUAL REPORTS ABSTRACTS

Current
Business information from annual reports/

Financial data, directory information
Predicasts-Incorporated

DS, L
Domestic and international company, product, and industry information, such as new products, merges, forecasts of sales, etc./

Journals, reports, newspapers, bank letters
Predicasts, Incorporated B, DS, L

F+S INDEX OF CORPORATE

CHANGE, F+S INDEX

INTERNATIONAL, $\mathrm{F}+\mathrm{S}$

INDEX EUROPE
PTS FORECASTS

1971-
Worldwide forecasts which include market information, imports, exports, prices, sales, etc./

Trade journals, business publications, newspapers, reports
Predicasts, Incorporated

DS, L
SCOTT)

1972-1979
Literature on marketing and advertising of consumer goods and services/
PREDICASTS, WORLDCASTS
PTS MARKETING AND ADVERTISING REFERENCE SERVICE (MARS)

1984-
Predicasts, Incorporated

DS, L

Journals, newsletters, newspapers

PTS NEW PRODUCT ANNOUNCEMENTS 1985-
Full text of news releases issued directly by companies on new products/
Predicasts, Incorporated

DS, L

News releases

PTS NEWSLETTER DATABASE 1988-
Full text of specialized industry newsletters that provide concise information on companies, products, markets, and technologies/

Newsletters
Predicasts, Incorporated

DS, L
Data on products and services of the chemical, computer, communication, energy industries, etc./
(PREDICASTS

AND TECHNOLOGY)

1972-

Newspapers, reports, journals

Predicasts, Incorporated B, DS, L

Various newsletters 
DATA BASE AND DATES COVERED
DESCRIPTION/

PRINCIPAL SOURCES
PRODUCER AND

HARD COPY COUNTERPART
VENDOR AND/OR DATA

BASE INQUIRIES
PTS TIME SERIES

Coverage varies
Annual data on U.S. production, Predicasts, Incorporated wages, prices, etc., for all types of industries, products, and services as well as forecasts for key economic, demographic, industrial, and product time series/

Reports, studies
PREDICASTS' BASEBOOK

National Institute of Standards $\quad P$ and Technology (NIST), Research Information Center (RIC)
Describes National Institute of Standards and Technology (NIST) research programs and projects and lists staff contacts for each/

Reports, press releases

$\begin{array}{ll}\text { PUBLIC INQUIRIES } & \text { Describes National Institute } \\ \text { Current } & \text { of Standards and Technology } \\ & \text { (NIST) research programs and } \\ \text { projects and lists staff contacts } & \text { for each/ }\end{array}$

PUBLIC INQUIRIES
DS, L

\section{QUAKELINE} 1987-
Literature on earthquakes, earthquake engineering, natural hazard mitigation, and related topics/

Journals, books, proceedings, reports, maps, data compilations, pamphlets, slides, videotapes
National Center for Earthquake B

Engineering Research Information Service
L

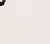

Full text of public opinion surveys conducted in the U.S./
Roper Center for Public Opinion Research
Surveys
Information on the U.S. book

publishing industry/

Directory information
R. R. Bowker Company

L

\section{AND WHOLESALERS}

Current
PUBLISHERS, DISTRIBUTORS AND WHOLESALERS OF THE UNITED STATES

\begin{tabular}{lll}
$\begin{array}{l}\text { PUBLIC OPINION ONLINE } \\
1960-\end{array}$ & $\begin{array}{l}\text { Full text of public opinion } \\
\text { surveys conducted in the U.S./ } \\
\text { Surveys }\end{array}$ & $\begin{array}{l}\text { Roper Center for Public Opinion } \\
\text { Research }\end{array}$ \\
\hline $\begin{array}{l}\text { PUBLISHERS, DISTRIBUTORS } \\
\begin{array}{l}\text { AND WHOLESALERS } \\
\text { Current }\end{array}\end{array}$ & $\begin{array}{l}\text { Information on the U.S. book } \\
\text { publishing industry/ }\end{array}$ & R. R. Bowker Company \\
& Directory information & PUBLISHERS, DISTRIBUTORS \\
& & $\begin{array}{l}\text { AND WHOLESALERS OF THE } \\
\text { UNITED STATES }\end{array}$
\end{tabular}


RAPRA TRADE NAMES 1976-
Trade names of interest to companies producing, supplying and using rubber and plastic materials and products/

Journals
RAPRA Technology Ltd. (U.K.) S
Worldwide literature on new manufacturing technologies/

Journals, books, proceedings, reports
BKI Information Services and Nottingham Polytechnic (U.K.)
DS

ROBOTICS, AUTOMATION

AND MANAGEMENT IN

MANUFACTURING BULLETIN

\section{REHABDATA}

1956-
Literature relevant to the rehabilitation of persons with physical or mental disabilities/
National Rehabilitation Information Center
B

Reports, monographs, proceedings, journals
RELIGION INDEX 1960-
Literature on religion and theology/

Books, journals, theses, book reviews
American Theological Library B, L Association

RELIGION INDEX
Listing of bibliographic records for works cataloged by the Library of Congress/
Carrollton Press, Incorporated

L
REMARC (RETROSPEC
MACHINE READABLE CATALOGING)

1897-1980

Books, proceedings

Worldwide comprehensive source of detailed information on over 26,000 research organizations/

Questionnaires, telephone calls
Gale Research Incorporated

L SERVICES DIRECTORY Current 
RESOURCES IN VOCATIONAL EDUCATION (RIVE)

1976-
Ongoing and recently completed research and development projects in vocational education/

Proposal abstracts and documents
National Center for Research

B in Vocational Education, Ohio State University

PROJECTS IN PROGRESS; CURRENT PROJECTS IN VOCATIONAL EDUCATION; RESOURCES IN VOCATIONAL EDUCATION

\section{REUTERS}

1987-
Access to current information on business and international news/
Reuters U.S., Incorporated

\section{L}

News stories

\section{ROBOTICS ABSTRACTS}

1973-
International literature of robotics/

Journals, proceedings, reports

Literature in German on regional planning, town planning, housing, building construction and civil engineering/
Bowker Electronic Publishing

DS

ROBOTICS ABSTRACTS
RSWB (RAUMORDNUNG STAEDTEBAU WOHNUNGSWESEN BAUWESEN) 1976-
Information Center for

Regional Planning and

Building Construction of the Fraunhofer Society

Journals, books, proceedings, reports, non-conventional literature

RTECS (REGISTRY OF TOXIC
EFFECTS OF CHEMICAL
SUBSTANCES)
Current

RTECS (REGISTRY OF TOXIC SUBSTANCES)

Cumrent
Chemical toxicity data for 90,000 substances/

U.S. National Institute for

I, L Occupational Safety and Health (NIOSH)

Journals, reports, data

REGISTRY OF TOXIC EFFECTS OF CHEMICAL SUBSTANCES
Society of Automotive Engineers S
ENGINEERS) GLOBAL MOBILITY from industry, government, and 1965- academic sectors on self-propelled vehicles/

Journals, proceedings

Liability information and hazards which threaten man and his environment/

Journals, proceedings, reports, books, patents, theses
SAE QUARTERLY ABSTRACTS

Cambridge Scientific Abstracts

\section{SAFETY}

1981- 
SANSS (STRUCTURE AND NOMENCLATURE SEARCH SYSTEM)

Current
Chemical nomenclature and substructure data for over 348,000 substances/
Chemical Information Systems, Incorporated
I

Data

SCAN-A-BID

1984
Information on development project opportunities in the third world/

Journals

Full text coverage of current developments in chemical medicine/

Journals
Development Business Scan-a-Bid DS

DEVELOPMENT BUSINESS

Scientific American, Incorporated MEDICINE

Current

\section{SCIENTIFIC AMERICAN MEDICINE}

Institute for Scientific Information DS, L, S *

Multidisciplinary index to the literature of science and technology/ 1974

Journals

SCIENCE CITATION INDEX

SDIM 1979

Data on specific compositions of metal alloys/

Fachinformationszentrum ev.

Journals, proceedings, books, reports, patents, standards, dissertations
July 1987-
SEC ONLINE
Full text database of reports filed by public companies with the U.S. securities and exchange commission/

SEC documents
SEC Online, Incorporated

$\mathbf{L}$
Synopsis of significant adverse drug reactions and interactions/

Reports
Excerpta Medica (Netherlands)

DS, L
Werkstoffe

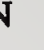


SERLINE (SERIALS ON-LINE) Current
Descriptive information about medical serials/

Serials held by major U.S.

medical libraries/
National Library of Medicine

NLM

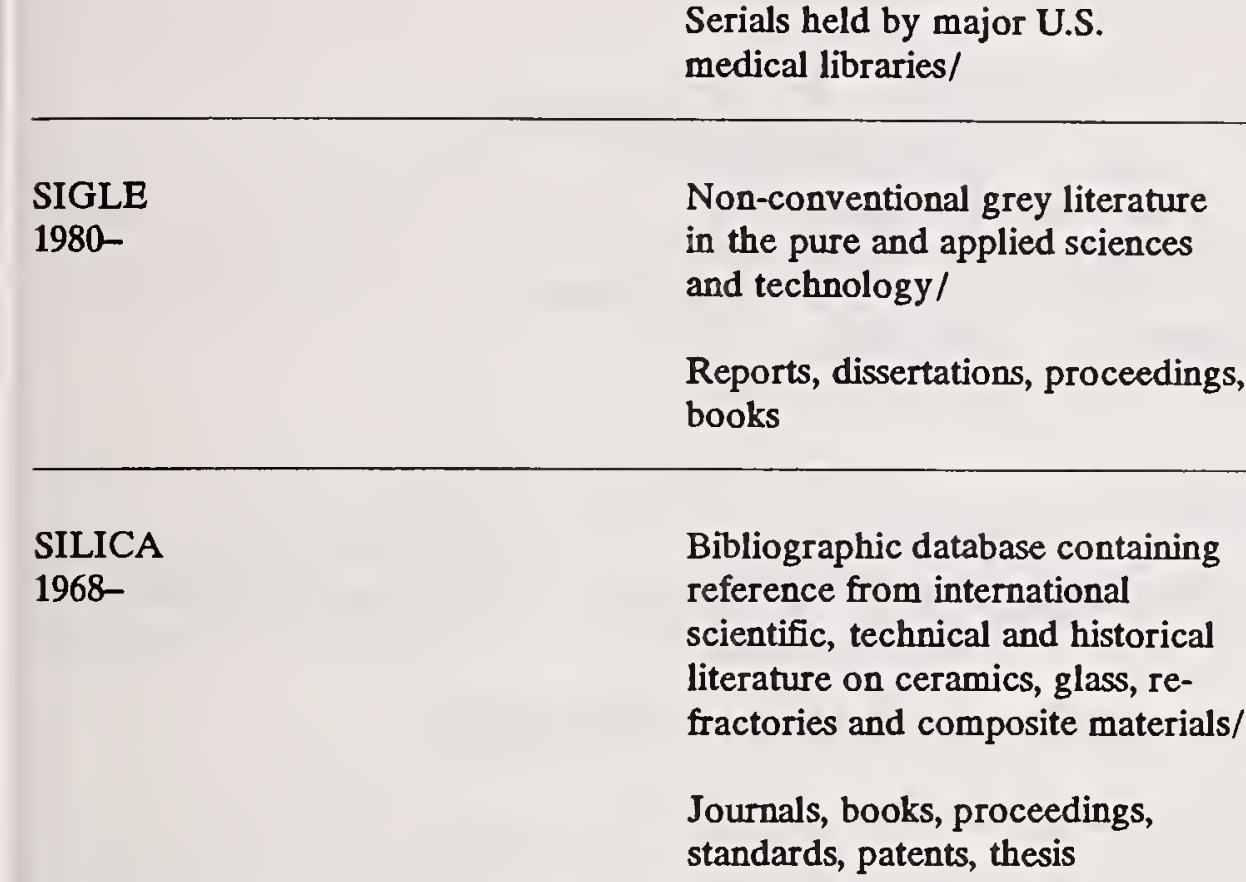

European Association for Grey STN

Literature Exploitation
STN

\section{SITRAFO}

1987-
Worldwide literature in social welfare, social planning and

Journals

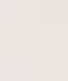

\section{SOCIAL PLANNING/POLICY AND DEVELOPMENT ABSTRACTS \\ 1979}

Journals, reports, books, patents, book reviews

\section{SMOKING AND HEALTH} BULLETIN
L

Sociological Abstracts,

B, L policy and social development/
Incorporated
Fachinformationszentrum
Information in French and German on current projects at the University of Strasburg, France and Karlsruhe/
Universitaet Karlsruhe (Germany) STN and Université Louis Pasteur (France)
Research projects
Worldwide scientific and techni- cal literature on all aspects of smoking, tobacco and tobacco use/
Office of Smoking and Health, Department of Health and Human Services
$\begin{array}{ll}\text { Bibliographic database containing } & \text { Fachinform } \\ \text { reference from international } & \text { (Germany) }\end{array}$

SOCIAL PLANNING/POLICY

AND DEVELOPMENT

ABSTRACTS

\section{SOCIAL SCISEARCH $1972-$}

Worldwide literature of the social Institute for Scientific Information sciences and humanities/

Journals
SOCIAL SCIENCES CITATION
INDEX

B, DS, L 
SOCIAL WORK ABSTRACTS

July 1977-
Literature on all aspects of social work including aging, alcoholism, drug abuse, crime, family and child welfare/

Journals, dissertations
National Association of Social

Workers, Incorporated

B
SOCIAL WORK RESEARCH AND ABSTRACTS
SOCIETE GENERALE DE

BANQUE

1979-
Literature on banking, economics, Societe Generale de Banque monetary problems, financial (Belgium) markets, etc./
DS

Journals

Worldwide literature in sociology and related disciplines/

Journals, monographs, theses, proceedings
Sociological Abstracts,

B, DS, L
1963-

SOLE

1984
Full text of II SOLE 24 ORE, Italy's leading financial daily newspaper/

Newspaper
24 ORE New Media (Italy)

DS

SOCIOLOGICAL ABSTRACTS

II SOLE 24 ORE

Informationzentrum

SOLIS

1945-
German language literature on the social sciences and their applications/

Journals, monographs
Sozial wissenschaften (Germany)

$-$

\section{SOVIET SCIENCE AND TECHNOLOGY 1975-}

Scientific and technological infor- IFI/Plenum Data Company

L mation which is published in

Soviet Bloc countries/

Journals, patents, reports, proceedings

SPEARHEAD

1985-
Guide to the European communities legislation/

European community sources
Department of Trade and Industry DS (U.K.)
Information on European community policies, initiatives and legislation/

Newsletters, periodicals, press

releases, legal documentation
Spicer's Centre for Europe Ltd. DS (U.K.)
DATABASE

1990- 
SPIN (SEARCHABLE PHYSICS INFORMATION NOTICES) 1975-
Worldwide coverage of the literature of physics, as well as astronomy, astrophysics, and geophysics/

Journals, proceedings of AIP
American Institute of Physics (AIP)
L CURRENT PHYSICS INDEX

\section{SPORT}

1975-(periodicals)

1949-(books)
Literature in the areas of sports, recreation, sports medicine, and physical education/

Journals, books, theses
Sport Information Research

B, DS, L

Canada

\section{SPORT AND RECREATION} INDEX

SSIE (SMITHSONIAN SCIENCE INFORMATION EXCHANGE) 1979-1982
Reports of government and privately funded scientific research projects/

Reports, on-going research
Smithsonian Science Information

Exchange, Incorporated

L
STANDARD AND POOR'S NEWS June 1979-
Information on companies including financial statements, sales, mergers/

Newspapers, reports, news releases, ticker services

\section{NOTICE OF RESEARCH} PROJECT
Standard and Poor's Corporation L

CUMULATIVE NEWS, DAILY NEWS
STANDARD AND POOR'S REGISTER-BIOGRAPHICAL Current
Personal and professional data on business executives/

Biographical data
Standard and Poor's Corporation

L
STANDARD AND POOR'S REGISTER OF CORPORATIONS, DIRECTORS, AND EXECUTIVES

\section{STANDARD AND POOR'S REGISTER-CORPORATE Current}

Business and financial information on more than 8000 publicly-held

U.S. corporations/
Standard and Poor's Corporation

L

Reports, press releases

Listing of all government and National Standards Association

L

\section{STANDARDS AND SPECIFICATIONS Current}

industry standards, specifications, and related documents/

Standards 
STANDARDS SEARCH

Current
Index to the Society of Automotive Engineers (SAE) and the American Society for Testing and Materials (ASTM) standards/

Standards
SAE/ASTM

S

THE ANNUAL BOOK OF ASTM

STANDARDS, THE SAE HAND-

BOOK, THE SAE AEROSPACE

INDEX, THE SAE AMS INDEX

OF AEROSPACE MATERIAL

SPECIFICATIONS

\section{STEELTUF}

Unevaluated test results characterizing the toughness of more than 100 grades of steels used in the power industry/

Unpublished data
Electric Power Research Institute (EPRI)/Materials Properties Council
STN

International literature on bio-

Bowker Electronic Publishing

L, S

\section{SUPERTECH \\ 1973-ROBOTS, BIOTECHNOLOGY 1984-AI, CAD/CAM}

technology, artificial intelligence, robotics, computer aided design, computer aided manufacturing and telecommunications/

Journals, proceedings, reports, books
TELEGEN REPORTER REVIEW, AI ABSTRACTS, CAD/CAM ABSTRACTS, ROBOMATIX REPORTER, TELECOMMUNICATION ABSTRACTS
Worldwide coverage of the literature on all aspects of coatings applied to materials/

Journals, proceedings, books, patents

International literature on banking and finance/

Newspapers, journals, internal publications

\section{SURFACE COATINGS ABSTRACTS \\ 1976-}

Paint Research Association (U.K.)

WORLD SURFACE COATINGS ABSTRACTS

Schweizerische Volksbank

DS (Switzerland)

S
1980-
Biomedical periodical publications held in Swiss libraries/ JOURNALS Current
Secretariat RPM/VMZ

DS
(Switzerland)
N 


\section{TA (TECHNOLOGY}

ASSESSMENT)

1975-
Literature in the field of technology assessment/

Reports, journals
Kernforschungszentrum

STN
Tax Notes Today

L

\section{Analytical summaries with the full text of all important legisla- \\ tive, regulatory, judicial and
policy documents regarding
federal taxation/ \\ tive, regulatory, judicial and
policy documents regarding
federal taxation/ \\ tive, regulatory, judicial and
policy documents regarding
federal taxation/ \\ News stories, legislation, regulations, cases \\ 1987- \\ AX NOTES TODAY}

\section{TEIKOKU DATABANK: JAPANESE COMPANIES} Current
Profiles of 45,000 Japanese corporations/
SCAN C2C, Incorporated

L

Directory information

$\begin{array}{lll}\text { TEXTILE TECHNOLOGY DIGEST } & \begin{array}{l}\text { International literature of the } \\ \text { textile industry/ }\end{array} & \text { Institute of Textile Technolog } \\ \text { 1978- } & \begin{array}{l}\text { Journals, reports, books, theses, } \\ \text { patents }\end{array} & \begin{array}{l}\text { TEXTILE TECHNOLOGY } \\ \text { DIGEST }\end{array}\end{array}$

THOMAS NEW INDUSTRIAL Information on new industrial PRODUCTS 1985-
Thomas Publishing Company, Incorporated
L products/
L

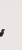

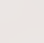

(2)

\begin{tabular}{|c|c|c|c|}
\hline & Press releases & - & \\
\hline \multirow[t]{2}{*}{$\begin{array}{l}\text { THOMAS REGISTER ONLINE } \\
\text { Current edition }\end{array}$} & $\begin{array}{l}\text { Information on what is made in } \\
\text { the United States, who makes it } \\
\text { and where it is made/ }\end{array}$ & Thomas Publishing Company & $\mathbf{L}$ \\
\hline & Product and company information & \multicolumn{2}{|l|}{$\begin{array}{l}\text { THOMAS REGISTER OF } \\
\text { AMERICAN MANUFACTURERS }\end{array}$} \\
\hline \multirow[t]{2}{*}{$\begin{array}{l}\text { TIBKAT (TIB-KATALOG) } \\
\text { 1983- } \\
\text { All journal holdings }\end{array}$} & $\begin{array}{l}\text { Catalog of the holdings of the } \\
\text { Central Special Library for } \\
\text { Technology and Science } \\
\text { (Technische Informations- } \\
\text { bibliothek)/ }\end{array}$ & \multirow[t]{2}{*}{$\begin{array}{l}\text { Universitaetsbibliothek und TIB } \\
\text { (Germany) }\end{array}$} & \multirow[t]{2}{*}{ STN } \\
\hline & $\begin{array}{l}\text { Journals, books, reports, } \\
\text { proceedings, theses }\end{array}$ & & \\
\hline
\end{tabular}


Journals, proceedings, patents, standards, books, reports

TOXIINE

1965-
Worldwide literature on animal and human toxicity studies, effects of environmental chemicals and pollutants, adverse drug reactions, etc./

Journals, reports
National Library of Medicine

B, DS, L, NLM
TOXICITY BIBLIOGRAPHY, PESTICIDES ABSTRACTS, CHEMICAL-BIOLOGICAL ACTIVITIES, etc.
TOXLIST

1979
Information about chemical substances listed on the TSCA Inventory/
American Petroleum Institute

\section{STN}

Chemical data

TOXNET

Current
Full text database on toxic substances including methods of packaging, shipping and storing human and animal toxicities, clean-ups of spills and antidotes for poisonings/

Toxicity data
National Library of Medicine

NLM
Full text for major articles in trade and general business publications /

Journals, newspapers, books, reports

\section{Information Access Company}

B, L
TRA
Trade, industry, and commerce related information/

Journals, newspapers, books, reports
Information Access Company

B, DS, L 1981-

TRADE AND INDUSTRY INDEX 
TRADE NAMES DATABASE

Current edition
Worldwide directory of consumer brand names and their owners or distributors/

Questionnaires, published sources
Gale Research, Incorporated

L

BRANDS AND THEIR COMPANIES, INTERNATIONAL BRANDS AND THEIR COMPANIES

TRADEMARKSCAN-FEDERAL 1884-
Information on all active registered and pending trademarks on file at the U.S. Patent and Trademark Office/

Trademarks
Thomson and Thomson

L

\section{TRADEMARKSCAN-STATE Current}

Company and product information for trademarks registered in the states and Puerto Rico/
Thomson and Thomson

L

Trademarks

British trademarks and service

Thomson and Thomson

L, S

marks/

Patents, trademarks

\section{TRCTHERMO}

Current
Numeric file containing evaluated thermodynamic data on 7000 compounds/

Thermodynamic data
Thermodynamic Research Center, STN Texas A\&M University

\section{TRC THERMODYNAMIC} TABLES
TRINET COMPANY DATABASE Current
Directory file providing address,

Trinet, Incorporated

L financial and marketing information on U.S. single and multiestablishment companies/

U.S. Bureau of the Census statistics, reports, journals

\section{TRINET US BUSINESS}

Current
Directory file providing address, financial and marketing information on U.S. establishments with twenty or more employees/

U.S. Bureau of the Census statistics, reports, journals 


\section{TRIS (TRANSPORTATION RESEARCH INFORMATION SERVICES) \\ 1964}

Comprehensive information on highway, maritime, railroad, and air transportation/

Journals, ongoing research projects, reports
Transportation Research Board, National Research Council
L

International coverage of agricul- Koninklijk Instituut voor den

TROPAG

1975ture and related topics relevant to the tropics and subtropics/

Tropen (The Netherlands)

HRIS ABSTRACTS, MRIS

ABSTRACTS

Journals, theses, monographs, proceedings, reports

\section{ABSTRACTS ON TROPICAL} AGRICULTURE
TSCA CHEMICAL SUBSTANCES INVENTORY

Current
Compilation of chemical substances manufactured, imported or processed for commercial purposes in the United States/

Chemical substances
U.S. Environmental Protection Agency (EPA)

$\mathbf{L}$

\section{TOXIC SUBSTANCES \\ CONTROL ACT (TSCA) CHEMICAL SUBSTANCE INVENTORY}

\section{TSCAPP (TOXIC SUBSTANCES CONTROL ACT PLANT AND PROTECTION DATA) \\ Current}

References to non-confidential plant and production information for 55,000 chemical substances/
Chemical Information Systems,

I
$S$

(1)

\section{Reports, data}

Unpublished health and safety studies submitted to EPA under the Toxic Substances Control Act/
Environmental Protection Agency

B, DS, I, NLM

TSCATS (TOXIC SUBSTANCES
CONTROL ACT TEST
SUBMISSIONS)
Current

\section{Studies}

Literature on artificial intelli-

gence, expert systems and related topics/

Journals, proceedings, reports, books
The Turing Institute (U.K.) DS 1983-

\author{
TURING INSTITUTE \\ ABSTRACTS IN ARTIFICIAL \\ INTELLIGENCE
}


UFORDAT

1974
Environmental research database on current and completed research and development projects in Austria, Switzerland and Germany/

Research projects
Umweltbundesamt (Germany)

DS, STN
Comprehensive directory of the names and addresses of importers of specific products into the United Kingdom/

Directory information
UK IMPORTERS

1989
Bibliographic database in German dealing with environmental problems of German speaking countries/

Journals, reports, monographs
Umweltbundesamt (Germany)

DS, STN

1976-

B, L
D-S Marketing Ltd. (U.K.)

DS

\section{Worldwide information on periodicals, serials, annuals, etc./ \\ Periodicals \\ R. R. Bowker Company PERIODICALS DIRECTORY Current \\ ULRICH'S INTERNATIONAL \\ ULRICH'S INTERNATIONAL PERIODICALS DIRECTORY, IRREGULAR SERIALS AND ANNUALS}

UMI ARTICLE CLEARINGHOUSE

1978-
Publications for purchase available from University Microfilms, Incorporated/
UMI/Data Courier

B

UMI publications

UPI NEWS

April 1983-
Full text of news stories carried on the United Press International wire/
United Press International

L

News items

Registration details for all active copyright and mask-work registrations on file at the U.S. copyright office/
DIALOG Information Services,

L

\section{U.S. C'OPYRIGHTS 1978-}

\section{Copyright data}


U.S. POLITICAL SCIENCE DOCUMENTS (USPSD) 1975-
Comprehensive literature on all aspects of political science/

Journals
NASA Applications Center,

University of Pittsburgh

\section{U.S. POLITICAL SCIENCE} DOCUMENTS
USA TODAY DECISIONLINE

Most recent 2 weeks
Concise news on the significant developments of the days top stories/

Newspaper
Gannett News Media

DS
L

\begin{tabular}{lll} 
& Newspaper & USA TODAY \\
$\begin{array}{l}\text { USCLASS (U.S. PATENT MAS- } \\
\begin{array}{l}\text { TER CLASSIFICATION FILE) } \\
1790-\end{array}\end{array}$ & $\begin{array}{l}\text { Classification information on } \\
\text { patents issued by the U.S. Patent } \\
\text { and Trademark Office/ }\end{array}$ & $\begin{array}{l}\text { Derwent Publications Ltd. } \\
\text { (U.K.) }\end{array}$ \\
& Patents & S \\
$\begin{array}{l}\text { USPA (U.S. PATENT ALERT) } \\
1970-\end{array}$ & $\begin{array}{l}\text { All information found on the } \\
\text { front page of a U.S. patent } \\
\text { plus full claims information/ }\end{array}$ & $\begin{array}{l}\text { Derwent Publications Ltd. } \\
\text { (U.K.) }\end{array}$ \\
& Patents & S \\
\hline
\end{tabular}

\section{VADEMECUM} Current
Information in German on teaching and research institutions and their staff in Germany/

Directory information
Fachinformationszentrum Karlsruhe (Germany)

\section{VADEMECUM DEUTSCHER LEHR- UND FORSCHUNGSSTAETTEN}

\section{VOCATIONAL EDUCATION CURRICULUM MATERIALS (VECM) 1977-}

\section{Current print and nonprint vocational education and technical curriculum materials/}

National Center for Research in Vocational Education, Ohio State University

Books, audiovisuals

\section{VOLKSWAGENWERK} 1971-
Literature on automobile technology /

Journals, proceedings, theses, books
Volkswagenwerk (Germany)

DS
B 
VTB (VERFAHRENSTECHNISCHE Worldwide literature on chemical Bayer Ag BERICHTE) engineering in Germany/

1966-

Journals, reports, books

WASHINGTON POST ONLINE 1983-
Full text of the WASHINGTON Washington Post Company POST/

Newspaper

Full text of official White House and U.S. Department of State news and policy information/

Speeches, news conferences, interviews, etc.
WASHINGTON PRESSTEXT

1981-1989
Literature on all aspects of nonradioactive waste management/

Journals, books, reports, patents, proceedings, newspapers
Presstext News Service

L

WASHINGTON POST

WEEKLY COMPILATION OF PRESIDENTIAL DOCUMENTS; STATE DEPARTMENT BULLETIN

Waste Management Information

S Bureau
L
1973-

\section{WASTEINFO}

Index to publications of the American Water Works Association and AWWA Research Foundation/

Reports, proceedings, books, journals
American Water Works Association

L
1971-
Comprehensive literature covering all aspects of the joining of metals and plastics/
The Welding Institute (U.K.)

S
WELD
1967-
Journals, reports, books, patents, theses, standards

JOURNAL AWWA 
WHO MAKES MACHINERY Current
Listing of mechanical engineering products manufactured and offered for sale by about 4400 companies in Germany/
Hoppenstedt Wirtschafts Verlag

DS
WHO OWNS WHOM

Current
Information on the corporate structure of parent companies and their subsidiaries/

Questionnaires, interviews, reports, newspapers, journals
Dun \& Bradstreet Ltd. (U.K.)

DS
Information on 51,000 German companies and their products/
Bezugsquellennachweis für den
WHO OWNS WHOM
Current

\section{UPPLIES WHAT}

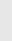

T

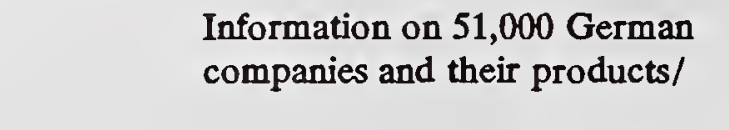
GmbH (Germany)
Einkauf "wer liefert was?"

\section{DS

$S$

.

\begin{abstract}
WHO'S WHO IN TECHNOLOGY Current
\end{abstract}

Biographical profiles of leading scientists and engineers in North America from 46 disciplines/

Biographical data

Listing of 120,000 mass spectra of chemical substances/

Data

Research Publications

WHO'S WHO IN TECHNOLOGY

John Wiley and Sons, I

WILEY MASS SPECTRAL SEARCH SYSTEM 1950-
Incorporated/Cornell University, Chemistry Department

\section{REGISTRY OF MASS SPECTRAL DATA}

WORLD AFFAIRS REPORT 1970-
Digest of news presenting the world as seen by Moscow/

Newspapers
California Institute of International Affairs, Stanford University

WORLD AFFAIRS REPORT
$\mathrm{L}$

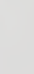


WORLD TEXTILES

1970-
World literature of textiles and the textile industry/

Journals, patents, standards, books, reports
Elsevier Science Publishers Ltd. L

WORLD TEXTILE

ABSTRACTS
WORLD TRANSLATIONS INDEX Translations of the literature 1984 from all languages in all fields of science and technology/

Translations
ITC (Netherlands)/CNRS (France) L

WORLD TRANSLATIONS

INDEX
WPI (WORLD PATENTS INDEX) 1963-
Comprehensive international information relating to patents and patent specifications/

Patents
Derwent Publications, Ltd.

L, S

CENTRAL PATENTS INDEX, WORLD PATENTS INDEX

Literature on water-related aspects of the life, physical, and social sciences/

Monographs, journals, reports
Water Resources Scientific

L

Information Center, U.S.

Department of the Interior

SELECTED WATER RESOURCES ABSTRACTS
Coverage of the world's zoologi- BIOSIS cal literature with emphasis on systematic/taxonomic information/

Serials, theses, proceedings,

journals
B, L

\begin{abstract}
ZOOLOGICAL RECORD 1978-

ABSTRACTS)

1968-
\end{abstract}

ZOOLOGICAL RECORD 
Aerospace and Aeronautical Engineering

Agriculture and Agricultural Engineering

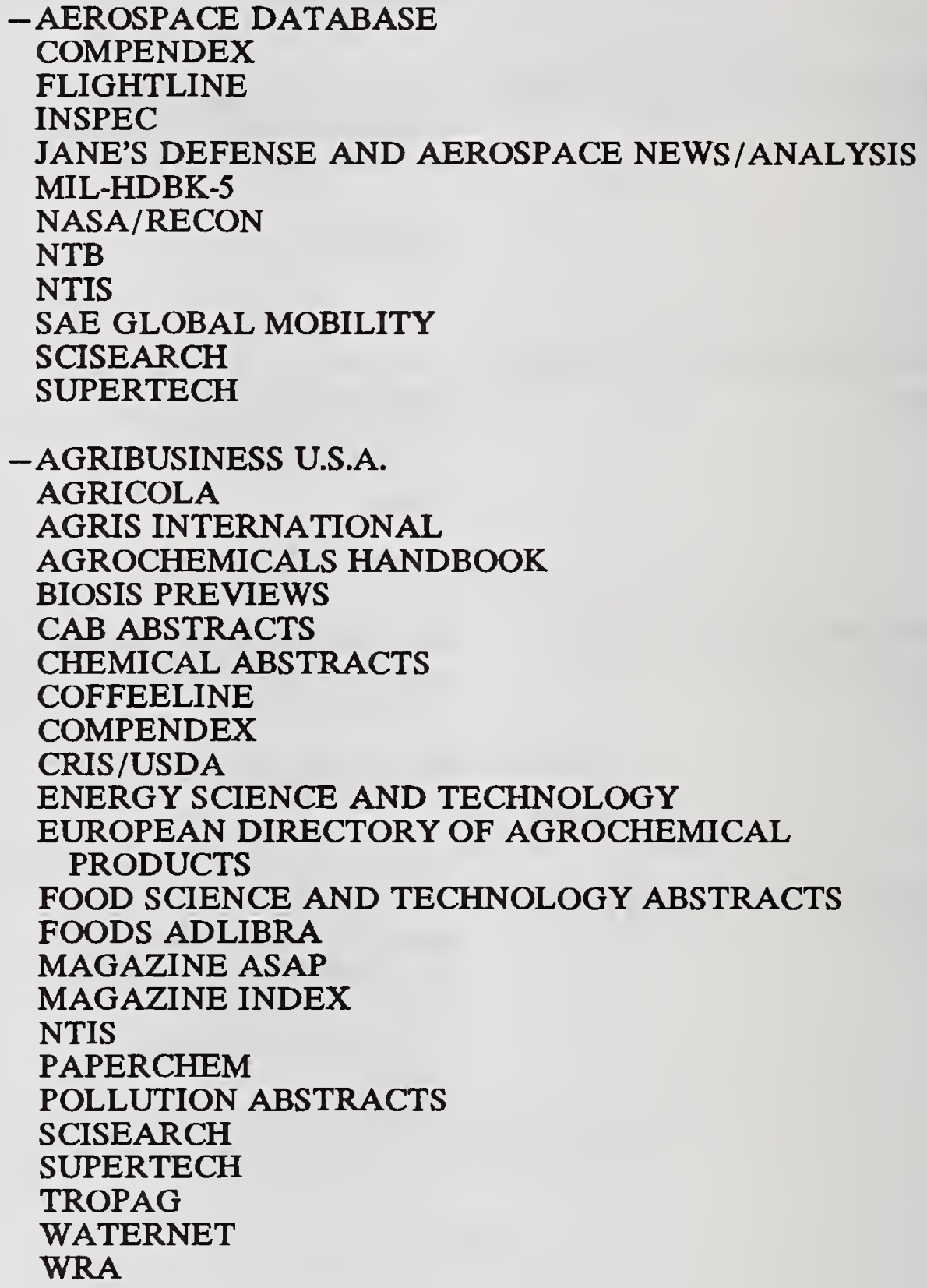

Arts and Humanities 
Arts and Humanities (cont.)

Audiovisual Media

Awards

Bioengineering/Biotechnology
CAB ABSTRACTS

MAGAZINE ASAP

MAGAZINE INDEX

MAGILL'S SURVEY OF CINEMA

MLA BIBLIOGRAPHY

RILM ABSTRACTS

-A-V ONLINE

AIM/ARM

AVLINE

NARIC

VOCATIONAL EDUCATION CURRICULUM MATERIALS

-AWARDS DATABASE

- AGRIBUSINESS U.S.A.

BIKE

BIOCOMMERCE ABSTRACTS AND DIRECTORY

BIOQUIP

BIOSIS PREVIEWS

BIOTECHNOLOGY

CAMBRIDGE SCIENTIFIC ABSTRACTS LIFE SCIENCE

CHEMICAL ENGINEERING AND BIOTECHNOLOGY

ABSTRACTS

COMPENDEX

CURRENT BIOTECHNOLOGY ABSTRACTS

DECHEMA

DEQUIP

EMBASE

INSPEC

MEDLINE

SUPERTECH

- AMERICAN MEN AND WOMEN OF SCIENCE BIOGRAPHY MASTER INDEX

MARQUIS WHO'S WHO

STANDARD AND POOR'S REGISTER-BIOGRAPHICAL WHO'S WHO IN TECHNOLOGY

Biology

See: Life Sciences, Medicine

Buildings
- COMPENDEX

ENERGY SCIENCE AND TECHNOLOGY

FEDERAL RESEARCH IN PROGRESS

HUD USER ONLINE

ICONDA

NTIS

QUAKELINE

RSWB 


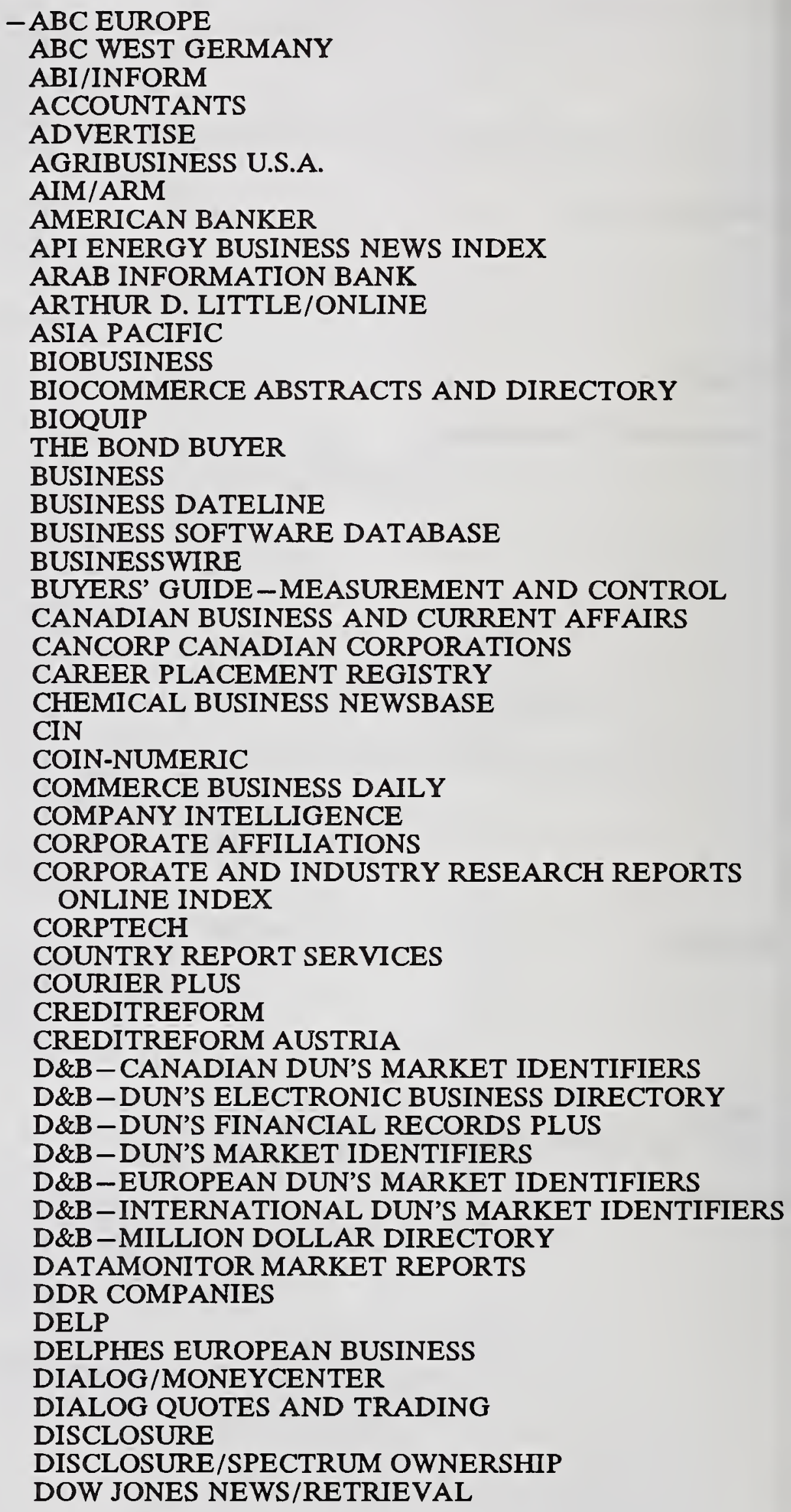


EBIS-EMPLOYEE BENEFITS INFOSOURCE

ECON BASE: TIME SERIES AND FORECASTING ECONOMIC LITERATURE INDEX

ECONOVO

ECOREGISTER

EUROMONITOR MARKET DIRECTION

EUROPEAN PHARMACEUTICAL MARKET RESEARCH ASSOCIATION DATABASE

EXTEL INTERNATIONAL FINANCIAL CARDS

EXTEL INTERNATIONAL NEWS CARDS

FEDERAL INDEX

FINANCIAL TIMES COMPANY ABSTRACTS

FINANCIAL TIMES FULLTEXT

FINDEX REPORTS AND STUDIES

FINIS

FIRMIMPORT/FIRMEXPORT

FOODS ADLIBRA

FOREIGN TRADE AND ECONOMIC ABSTRACTS

FOUNDATION DIRECTORY

FOUNDATION GRANTS INDEX

FROST \& SULLIVAN MARKET RESEARCH REPORTS

FROST \& SULLIVAN POLITICAL RISK COUNTRY

REPORTS

GERMAN COMPANY DATABASE

THE GERMAN INDUSTRY-MADE IN GERMANY

GRANTS

HARVARD BUSINESS REVIEW/ONLINE

HOPPENSTEDT AUSTRIA

HOPPENSTEDT BENELUX

HOPPENSTEDT DIRECTORY OF GERMAN COMPANIES

HOPPENSTEDT TREUHANDANSTALT

HSELINE

ICC BRITISH COMPANY DIRECTORY

ICC BRITISH COMPANY FINANCIAL DATASHEETS

ICC INTERNATIONAL ANNUAL REPORTS

ICC INTERNATIONAL BUSINESS RESEARCH

ICC KEYNOTES MARKET ANALYSIS

ICC STOCKBROKERS RESEARCH

IDD $M+A$ TRANSACTIONS

IMS MARKETLETTER DATABASE

INDUSTRY DATA SOURCES

INFOMAT INTERNATIONAL BUSINESS

INFOTRADE BELGIUM COMPANY DATABASE

INSPEC

INVESTEXT

INVESTOR'S DAILY

ISTP SEARCH

JAPAN ECONOMIC NEWSWIRE PLUS

JAPAN NEWS WIRE: COMLINE

JERUSALEM POST

JOURNAL OF COMMERCE 
KNIGHT RIDDER FINANCIAL NEWS

KOMPASS ASIA/PACIFIC

KOMPASS EUROPE

KOMPASS REGISTER OF INDUSTRY AND COMMERCE OF ISRAEL

KOMPASS UK

KREDITSCHUTZVERBAND VON 1870

KYODO NEW SERVICE

LABORDOC

LABORLAW

M\&A FILINGS

MCGRAW-HILL PUBLICATIONS ONLINE

MAGAZINE ASAP

MAGAZINE INDEX

MANAGEMENT CONTENTS

MANAGEMENT INFO WIRTSCHAFT

MEDIA GENERAL PLUS

MOODY'S CORPORATE NEWS -INTERNATIONAL

MOODY'S CORPORATE NEWS - US

MOODY'S CORPORATE PROFILES

NEW YORK TIMES

NEWSPAPER AND PERIODICAL ABSTRACTS

$1 \times 1$ GERMAN BUYERS' GUIDE

PAIS INTERNATIONAL

PHARMA MARKETING SERVICE

PHARMACONTACTS

PIERS IMPORTS

PIERS EXPORTS

PIRA

PNI

PTS AEROSPACE/DEFENSE MARKETS AND

TECHNOLOGY

PTS ANNUAL REPORTS ABSTRACTS

PTS F\&S INDEXES

PTS FORECASTS

PTS MARKETING AND ADVERTISING REFERENCE SERVICE

PTS NEW PRODUCT ANNOUNCEMENTS

PTS NEWSLETTER DATABASE

PTS PROMT

PTS TIME SERIES

REUTERS

SEC ONLINE

SOCIAL SCISEARCH

SOCIETE GENERALE DE BANKE

SOLE

STANDARD AND POOR'S CORPORATE DESCRIPTIONS STANDARD AND POOR'S NEWS

SVBI

TEIKOKU DATABANK

THOMAS NEW INDUSTRIAL PRODUCTS

THOMAS REGISTER ONLINE 
Business, Economics, Management (cont.)

Chemistry and Chemical Engineering
TRADE AND INDUSTRY ASAP

TRADE AND INDUSTRY INDEX

TRADE NAMES DATABASE

TRINET COMPANY DATABASE

TRINET US BUSINESS

UK IMPORTERS

WER GEHOERT ZU WEM

WHO OWNS WHOM

WHO SUPPLIES WHAT

-AEROSPACE DATABASE

AGRICOLA

AGROCHEMICALS HANDBOOK

ALUMINUM ASSOCIATION STANDARDS AND DATA

ALUMINUM FRACTURE TOUGHNESS DATABASE

AMERICAN CERAMIC ABSTRACTS

ANALYTICAL ABSTRACTS

API ENERGY BUSINESS NEWS INDEX

APILIT

APIPAT

APTIC

AQUIRE

ASFA

BEILSTEIN

C13-NMR/IR

CAMBRIDGE SCIENTIFIC ABSTRACTS ENGINEERING

CAPREVIEWS

CASREACT

CASSI

CCRIS

CERCLIS

CESARS

CFRBBS

CHAPMAN AND HALL CHEMICAL DATABASE

CHEM-INTELL

CHEM-INTELL TRADE AND PRODUCTION STATISTICS DATABASE

CHEMDEX

CHEMICAL ABSTRACTS

CHEMICAL ACTIVITY STATUS REPORT

CHEMICAL BUSINESS NEWSBASE

CHEMICAL ENGINEERING AND BIOTECHNOLOGY ABSTRACTS

CHEMICAL EXPOSURE

CHEMICAL REACTIONS DOCUMENTATION SERVICE CHEMICAL REGULATIONS AND GUIDELINES SYSTEM CHEMICAL SAFETY NEWSBASE

CHEMID

CHEMLINE

CHEMLIST

CHEMNAME

CHEMQUEST 
Chemistry and Chemical Engineering (cont.)

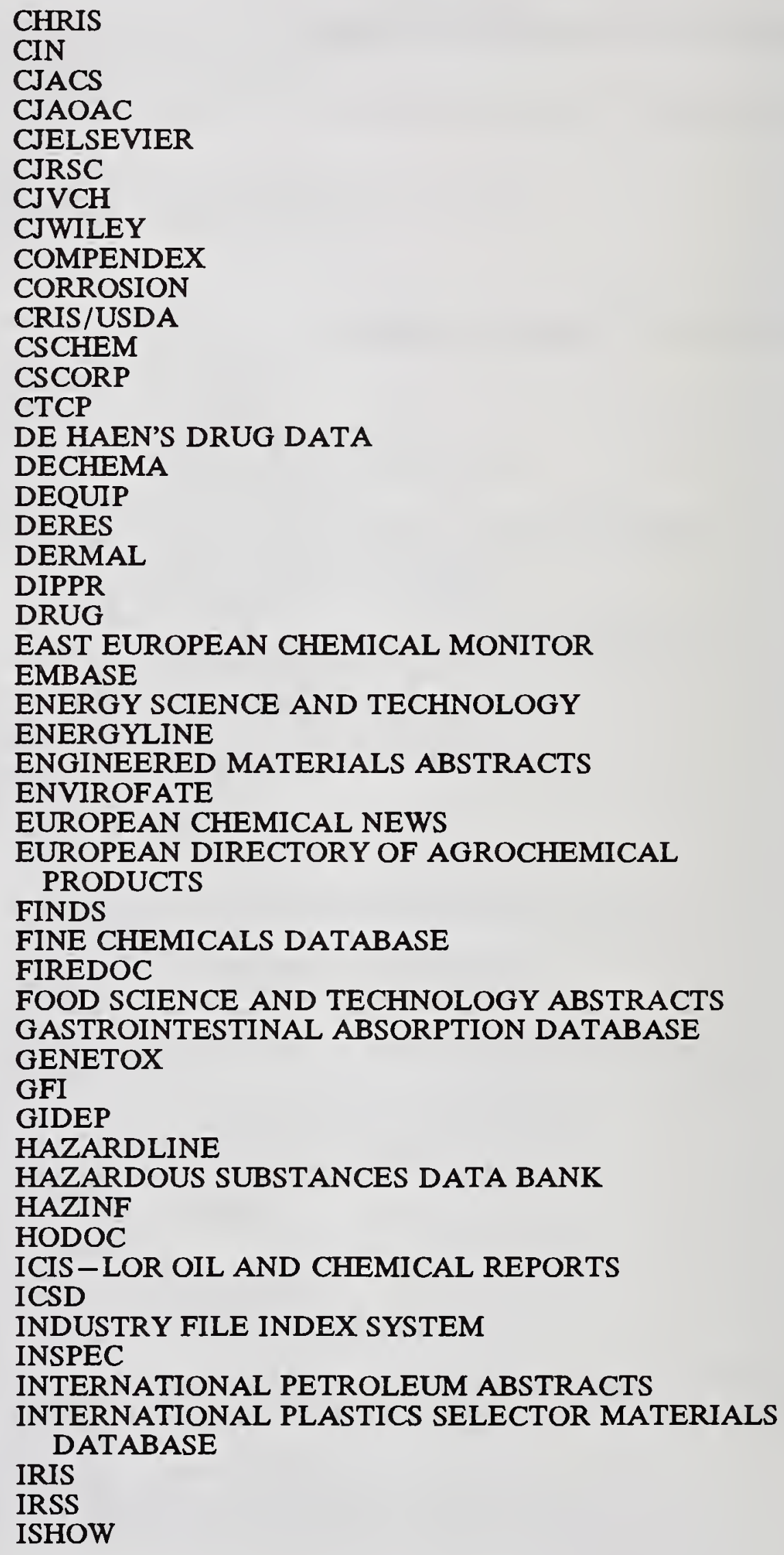




\section{GENERAL SUBJECT INDEX}

DATA BASE NAME

Chemistry and Chemical Engineering (cont.)

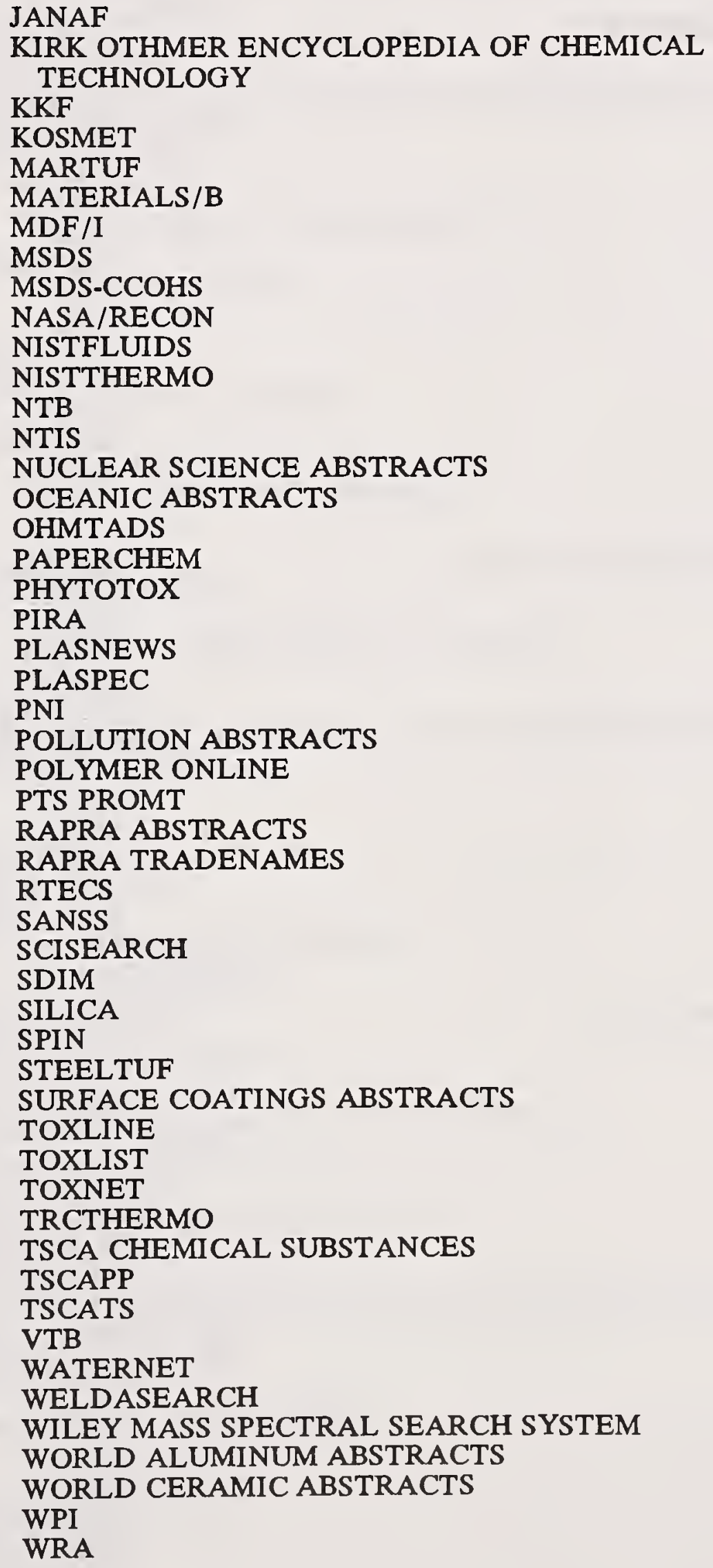


Civil Engineering

Communications and Language

Computer Science

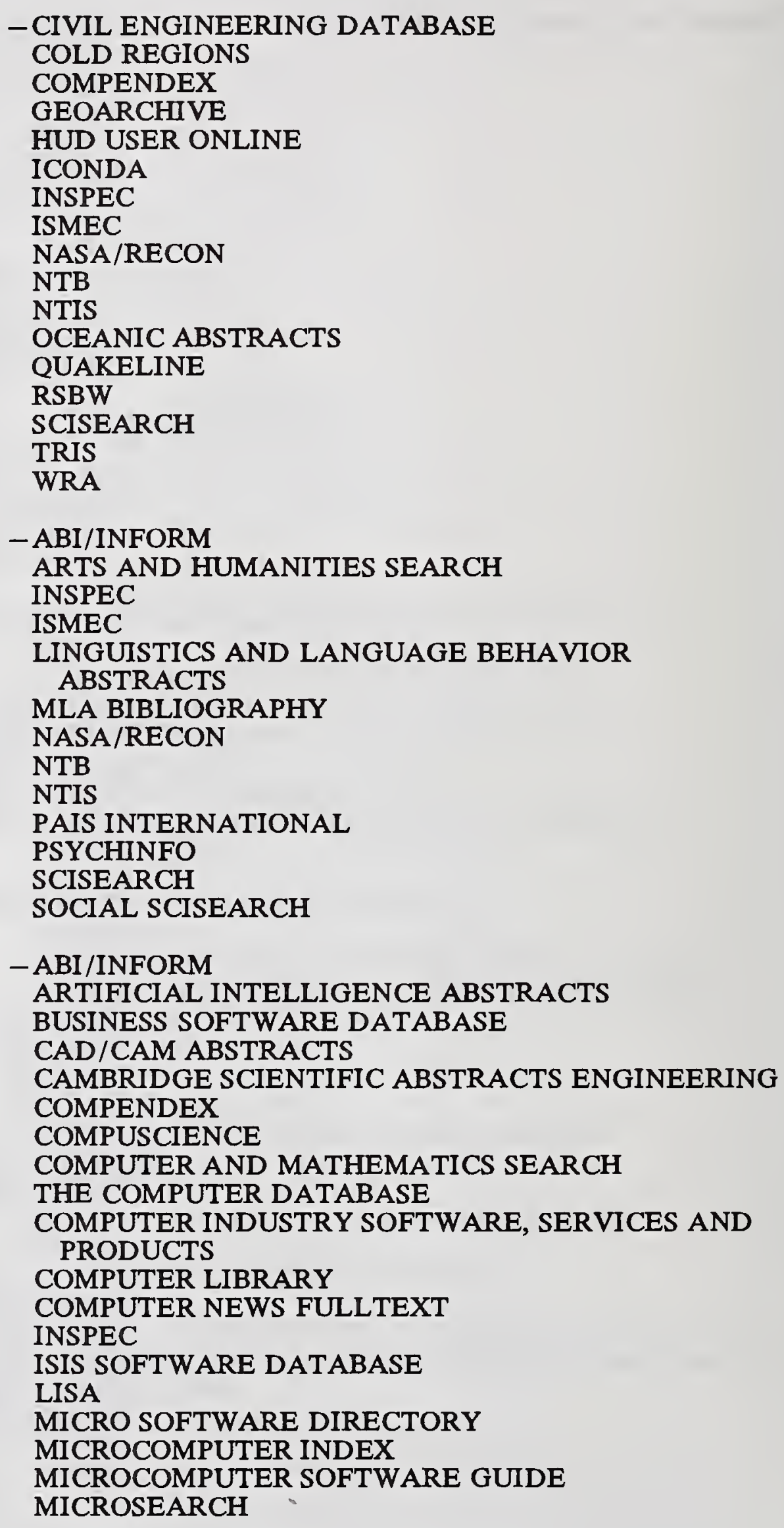


Computer Science (cont.)

Copyright

Cosmetics

Consumer Information

Current Research Projects

Earth and Space

See also: Aerospace and Aeronautical

Engineering Mining and Metallurgy
NASA/RECON

NTB

NTIS

ONLINE MICROCOMPUTER SOFTWARE GUIDE AND

DIRECTORY

SCISEARCH

SUPERTECH

TURING INSTITUTE DATABASE

--U.S. COPYRIGHTS

-KOSMET

- CONSUMER REPORTS

-AQUACULTURE

CHILD ABUSE AND NEGLECT

CRIS/USDA

CRSP

DENTALPROJ

EPD

FEDERAL RESEARCH IN PROGRESS

FORIS

FORKAT

JAPANESE GOVERNMENT AND PUBLIC RESEARCH IN PROGRESS

SITRAFO

SSIE

TRIS

UFORDAT

- AEROSPACE DATABASE

AQUACULTURE

AQUALINE

ASFA

COLD REGIONS

ECON

ENERGY SCIENCE AND TECHNOLOGY

GEOARCHIVE

GEOBASE

GEOMECHANICS ABSTRACTS

GEOREF

INSPEC

METEOROLOGICAL AND GEOASTROPHYSICAL ABSTRACTS

NASA/RECON

NTB

OCEANIC ABSTRACTS

SCISEARCH

SPIN

WATERNET

WRA 
Economics

See: Business, Economics, Management

Education

\author{
- ACADEMIC INDEX \\ AVLINE \\ BRITISH EDUCATION INDEX \\ CAREER PLACEMENT REGISTRY \\ ECER \\ ECON \\ THE EDUCATIONAL DIRECTORY \\ EDUCATIONAL TESTING SERVICE FILE \\ ERIC \\ GRADLINE \\ LINGUISTICS AND LANGUAGE BEHAVIOR
} ABSTRACTS

MENTAL MEASUREMENTS YEARBOOK

ONTARIO EDUCATION RESOURCES INFORMATION

DATABASE

PAIS INTERNATIONAL

PETERSON'S COLLEGE DATABASE

PETERSON'S GRADLINE

PSYCHINFO

RESOURCES IN VOCATIONAL EDUCATION

SOCIAL SCISEARCH

SPORT

VADEMECUM

VOCATIONAL EDUCATION CURRICULUM MATERIALS

Electronics and Electrical Engineering

See also: Civil Engineering

Mechanical Engineering

- AEROSPACE DATABASE

CAD/CAM ABSTRACTS

CAMBRIDGE SCIENTIFIC ABSTRACTS ENGINEERING COMPENDEX

THE COMPUTER DATABASE

ELECTRO/ELECTRONICS BUYERS' GUIDE

ELECTRONIC MATERIALS INFORMATION SYSTEM

ELECTRONIC PUBLISHING ABSTRACTS

ENERGY SCIENCE AND TECHNOLOGY

EPD

EPIA

GIDEP

INSPEC

NASA/RECON

NTB

NTIS

RESORS

SCISEARCH

SPIN

SUPERTECH

TRIS 
DATA BASE NAME

Environment (cont.)

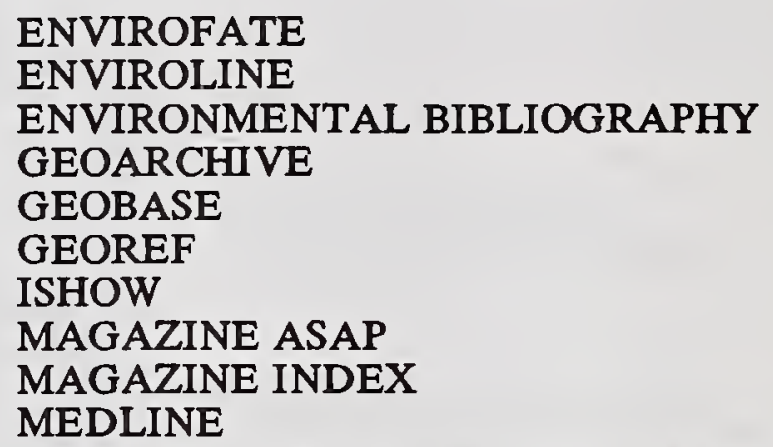

Food Science

See also: Agriculture and Agricultural Engineering

Forensic Science

Full Text Data Bases
-AGRICOLA BIOSIS PREVIEWS

CHEMICAL ABSTRACTS

FOOD SCIENCE AND TECHNOLOGY ABSTRACTS FOODS ADLIBRA

PACKAGING SCIENCE AND TECHNOLOGY ABSTRACTS SCISEARCH

-FORENSIC SCIENCE DATABASE

- ACADEMIC AMERICAN ENCYCLOPEDIA AERZTE ZEITUNG

AGRIBUSINESS U.S.A.

AIDS KNOWLEDGE BASE

AMERICAN BANKER

AP NEWS

BIBLE

THE BOND BUYER

BUSINESS DATELINE

BUSINESSWIRE 
GENERAL SUBJECT INDEX

DATA BASE NAME

Full Text Data Bases (cont.)

CELEX

CHICAGO TRIBUNE

CJACS

CJAOAC

CJRSC

CJVCH

CJWILEY

COMMERCE BUSINESS DAILY

COMPREHENSIVE CORE MEDICAL LIBRARY

COMPUTER NEWS FULLTEXT

CONSUMER DRUG INFORMATION FULLTEXT

CONSUMER REPORTS

COUNTRY REPORT SERVICES

DIOGENES

DOW JONES NEWS/RETRIEVAL

DRUG INFORMATION FULLTEXT

EVERYMAN'S ENCYCLOPEDIA

FEDERAL ACQUISITION REGULATIONS

FEDERAL NEWS SERVICE

FINANCIAL TIMES FULLTEXT

FLIGHTLINE

GENERAL PRACTITIONER

HARVARD BUSINESS REVIEW

ICC INTERNATIONAL ANNUAL REPORTS

ICC INTERNATIONAL BUSINESS RESEARCH

IMS MARKETLETTER DATABASE

INVESTEXT

JERUSALEM POST ELECTRONIC EDITION

JOURNAL OF COMMERCE

KNIGHT RIDDER FINANCIAL NEWS

LEXIS

MCGRAW-HILL PUBLICATIONS ONLINE

MAGAZINE ASAP

MAGAZINE INDEX

MAGILL'S SURVEY OF CINEMA

MARTINDALE ONLINE

NEW YORK TIMES

NEWSNET

NEWSWIRE ASAP

NEXIS

OAG ELECTRONIC EDITION

PAPERS

PHIND

PR NEWSWIRE

PTS NEW PRODUCT ANNOUNCEMENTS

PTS NEWSLETTER DATABASE

PUBLIC OPINION ONLINE

REUTERS

SCIENTIFIC AMERICAN MEDICINE

SEC ONLINE

SOLE 
Full Text Data Bases (cont.)

General Science and Technology/Miscellaneous
TAX NOTES TODAY

TOXNET

TRADE AND INDUSTRY ASAP

TRADE AND INDUSTRY INDEX

UPI NEWS

WASHINGTON POST ELECTRONIC EDITION

WASHINGTON PRESSTEXT

-ACADEMIC AMERICAN ENCYCLOPEDIA

ACADEMIC INDEX

ARAB INFORMATION BANK

ARTHUR D. LITTLE/ONLINE

ASI

BIBLIODATA

BOOK REVIEW INDEX

BOOKS IN PRINT

BRITISH BOOKS IN PRINT

BRITISH OFFICIAL PUBLICATIONS (HMSO)

CLAIMS/PATENTS

COMPUTER READABLE DATABASES

CONF

CONFERENCE PAPERS INDEX

CRSP

CUADRA DIRECTORY OF ONLINE DATABASES

CURRENT CONTENTS SEARCH

CURRENT TECHNOLOGY INDEX

D\&B DUN'S ELECTRONIC BUSINESS DIRECTORY

DIRECTORY OF AMERICAN RESEARCH AND TECHNOLOGY

DIRLINE

DISSERTATION ABSTRACTS ONLINE

DMS CONTRACT AWARDS

DMS CONTRACTORS

DROLS

ENCYCLOPEDIA OF ASSOCIATIONS

EVENTLINE

EVERYMAN'S ENCYCLOPEDIA

FAIRBASE

FHGPUBLICA

FORKAT

FTN

GENERAL PRACTITIONER

GIDEP

GPO MONTHLY CATALOG

INFOR

ISTP SEARCH

JANE'S DEFENSE AND AEROSPACE NEWS/ANALYSIS

JAPAN TECHNOLOGY-JTEC

JAPINFO

JICST-E 
General Science and Technology/Miscellaneous (cont.)

Geology

See: Earth and Space Mining and Metallurgy

Government Reports

\section{Grants}

\author{
KNOWLEDGE INDUSTRY PUBLICATIONS DATABASE \\ LC MARC \\ MCGRAW-HILL BUSINESS BACKGROUNDER \\ MAGAZINE ASAP \\ MAGAZINE INDEX \\ MONUDOC \\ MPDSEARCH \\ NATIONAL NEWSPAPER INDEX \\ NEW YORK TIMES \\ NEWSNET \\ NEWSWIRE ASAP \\ NTIS \\ OCLC \\ PASCAL \\ POPULAR MAGAZINE REVIEW ONLINE \\ PUBLIC INQUIRIES \\ PUBLIC OPINION ONLINE \\ PUBLISHERS, DISTRIBUTORS AND WHOLESALERS \\ REMARC \\ RESEARCH CENTERS AND SERVICES DIRECTORY \\ SCISEARCH \\ SIGLE \\ SOVIET SCIENCE AND TECHNOLOGY \\ SSIE \\ TA (TECHNOLOGY ASSESSMENT) \\ TAX NOTES TODAY \\ TIBKAT \\ TRADE NAMES DATABASE \\ ULRICH'S INTERNATIONAL PERIODICALS \\ DIRECTORY \\ UMI ARTICLE CLEARINGHOUSE \\ WHO'S WHO IN TECHNOLOGY
}

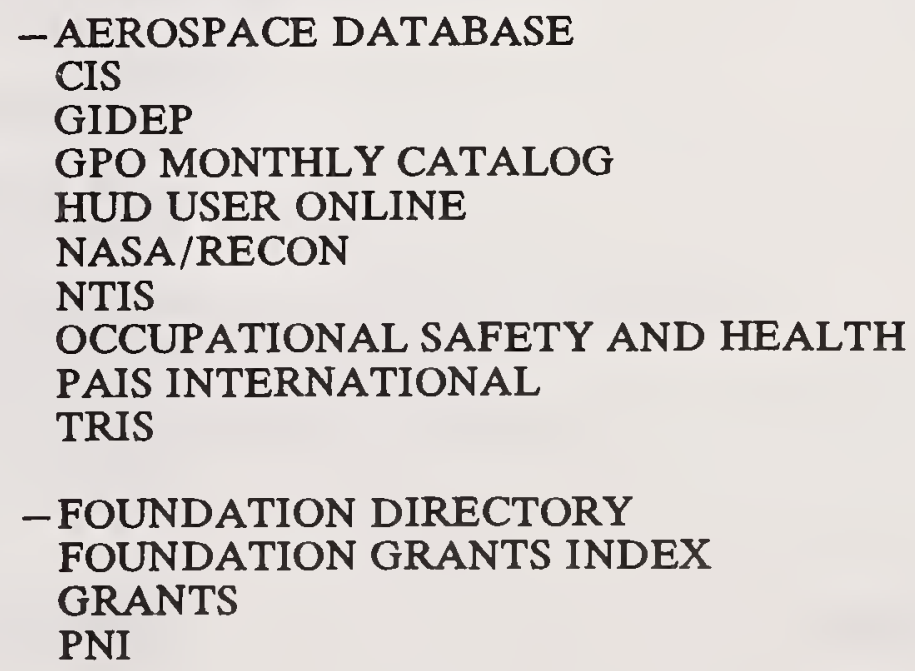


History

Information Science

Insurance

Law and Legislative Processes

Life Sciences

See also: Medicine
- AMERICA: HISTORY AND LIFE ARTBIBLIOGRAPHIES MODERN HISTLINE

HISTORICAL ABSTRACTS

UNITED STATES POLITICAL SCIENCE DOCUMENTS

- ABI/INFORM

AMERICAN LIBRARY DIRECTORY

ELECTRONIC PUBLISHING ABSTRACTS

ERIC

INFODATA

INFORMATION SCIENCE ABSTRACTS

INSPEC

LISA

NTIS

SCISEARCH

SOCIAL SCISEARCH

-INSURANCE ABSTRACTS

INSURANCE PERIODICALS INDEX

-ABI/INFORM

CELEX

CHEMICAL REGULATIONS AND GUIDELINES SYSTEMS

CHILD ABUSE AND NEGLECT

CIS

CONGRESSIONAL RECORD ABSTRACTS

CRIMINAL JUSTICE PERIODICAL INDEX

FEDERAL ACQUISITION REGULATIONS

FEDERAL INDEX

FEDERAL NEWS SERVICE

FEDERAL REGISTER

INDUSTRY FILE INDEX SYSTEM

LABORLAW

LEGAL RESOURCE INDEX

LEGAL STATUS

LEXIS

MANAGEMENT CONTENTS

NCJRS

PAIS INTERNATIONAL

SOCIAL SCISEARCH

SPEARHEAD

SPICER'S CENTRE FOR EUROPE DATABASE

TAX NOTES TODAY

UNITED STATES POLITICAL SCIENCE DOCUMENTS

WASHINGTON PRESSTEXT

WRA

-ACID RAIN ABSTRACTS

AGRICOLA

APTIC 


\section{SUBJECT}

Life Sciences (cont.)
DATA BASE NAME

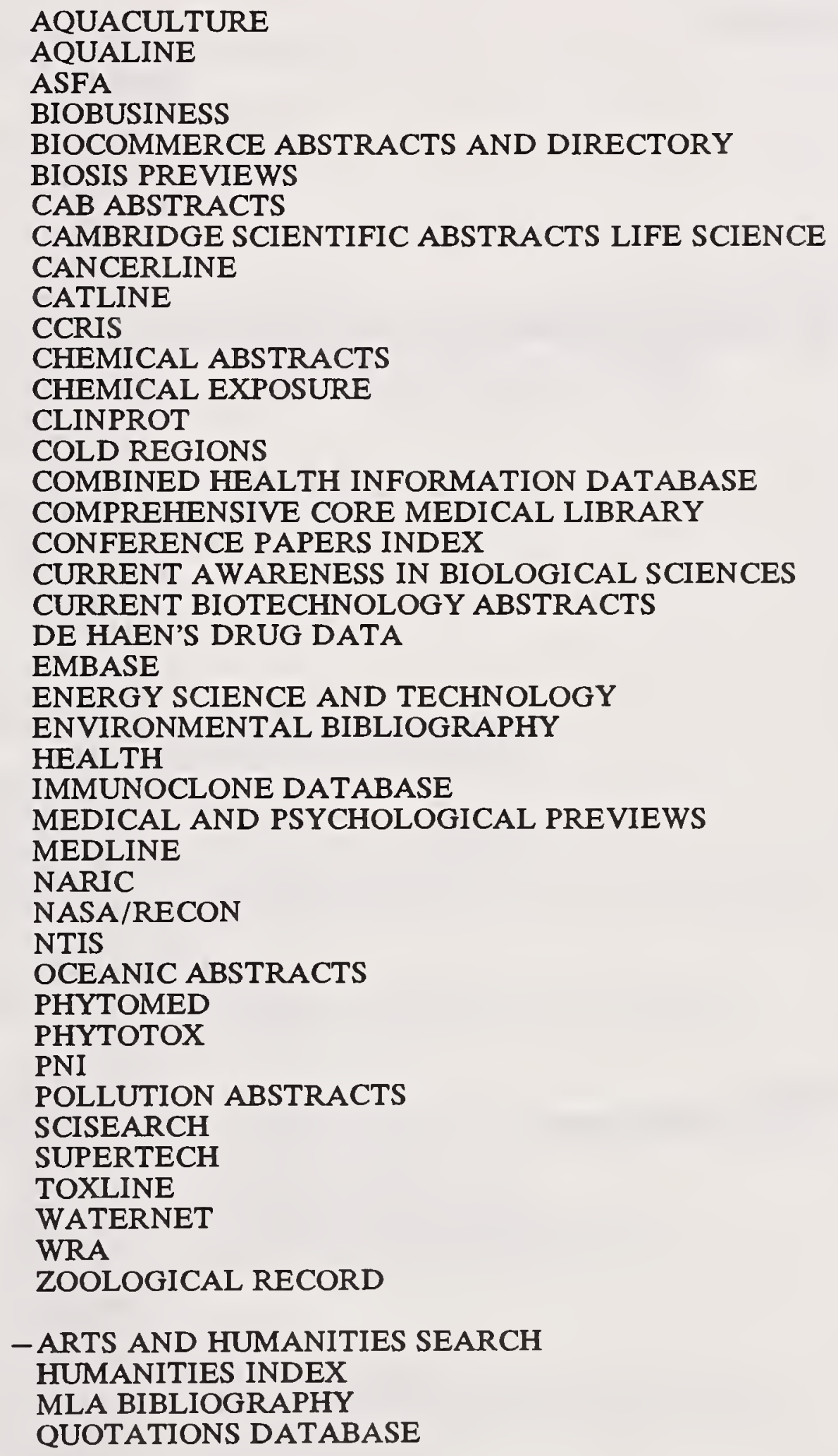

Management

See: Business, Economics, Management 
Mathematics

Mechanical Engineering See also: Electronics and Electrical Engineering

Medicine

See also: Life Sciences
- COMPUTER AND MATHEMATICS SEARCH DISSERTATION ABSTRACTS ONLINE

INSPEC

MATH

MATHEMATICAL DIDACTICS

MATHSCI

NTIS

SCISEARCH

- AEROSPACE DATABASE

AGRICOLA

AUTOMOTIVE INDUSTRY NEWS

CAD/CAM ABSTRACTS

CAMBRIDGE SCIENTIFIC ABSTRACTS ENGINEERING COMPENDEX

DETEQ

DKF DATABASE VEHICLE TEST REPORTS

ENERGY SCIENCE AND TECHNOLOGY

FLUIDEX

GIDEP

INSPEC

ISMEC

MOTOR INDUSTRY RESEARCH ASSOCIATION

NASA/RECON

NTIS

PAPERCHEM

RECENT ADVANCES IN MANUFACTURING

ROBOTICS ABSTRACTS

SAE GLOBAL MOBILITY

SCISEARCH

TRIS

VOLKSWAGENWERK

WHO MAKES MACHINERY

WPI

- ABLEDATA

AERZTE ZEITUNG

AGELINE

AIDS

AIDS KNOWLEDGE BASE

AIDSDRUGS

AIDSLINE

AIDSTRIALS

ALCOHOL AND ALCOHOL PROBLEMS SCIENCE DATABASE

ALCOHOL INFORMATION FOR CLINICIANS AND EDUCATORS DATABASE

ALLIED AND ALTERNATIVE MEDICINE

AVLINE 
DATA BASE NAME

Medicine (cont.)

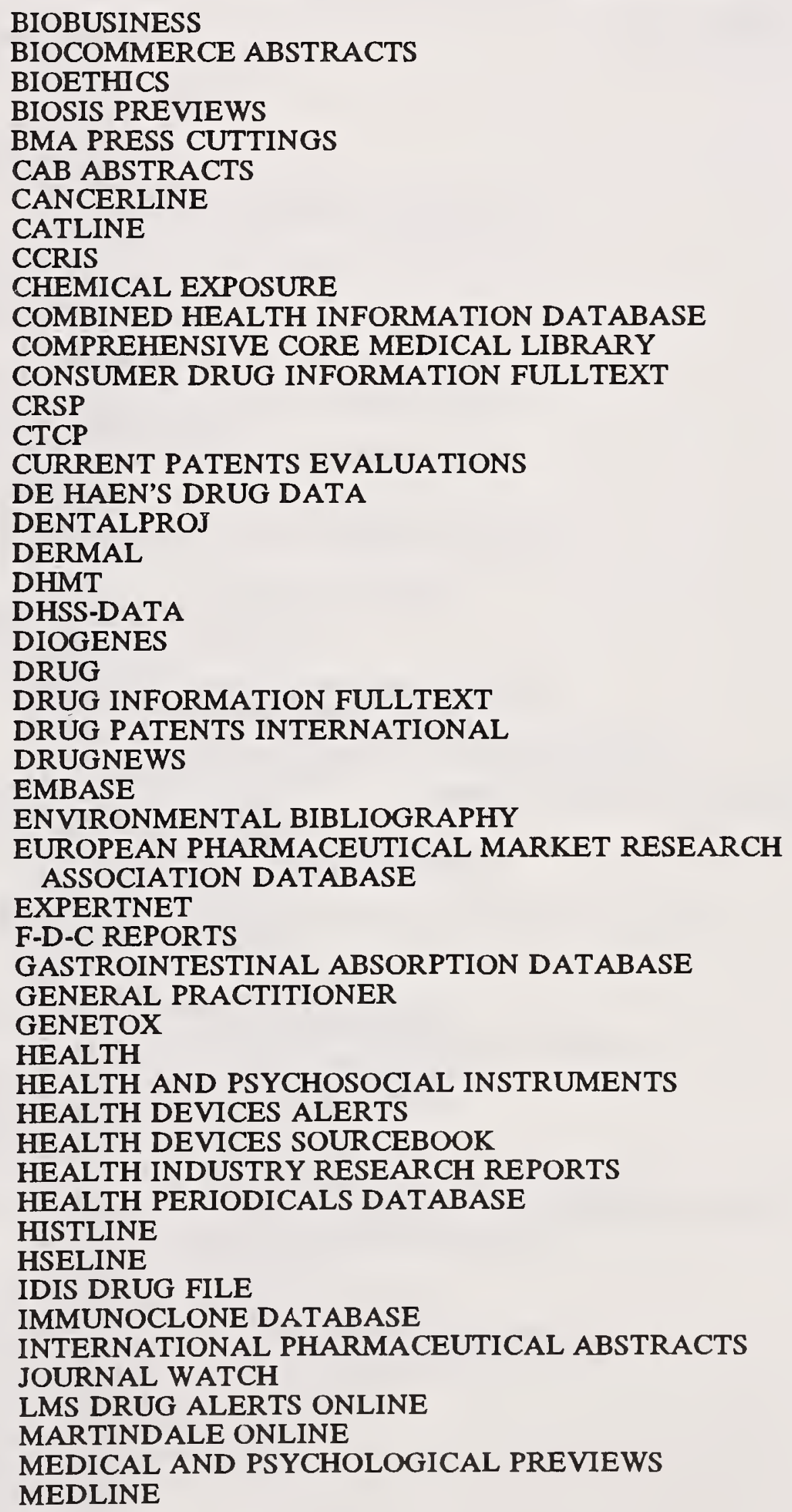


Medicine (cont.)

Metrology and Standardization

Mining and Metallurgy

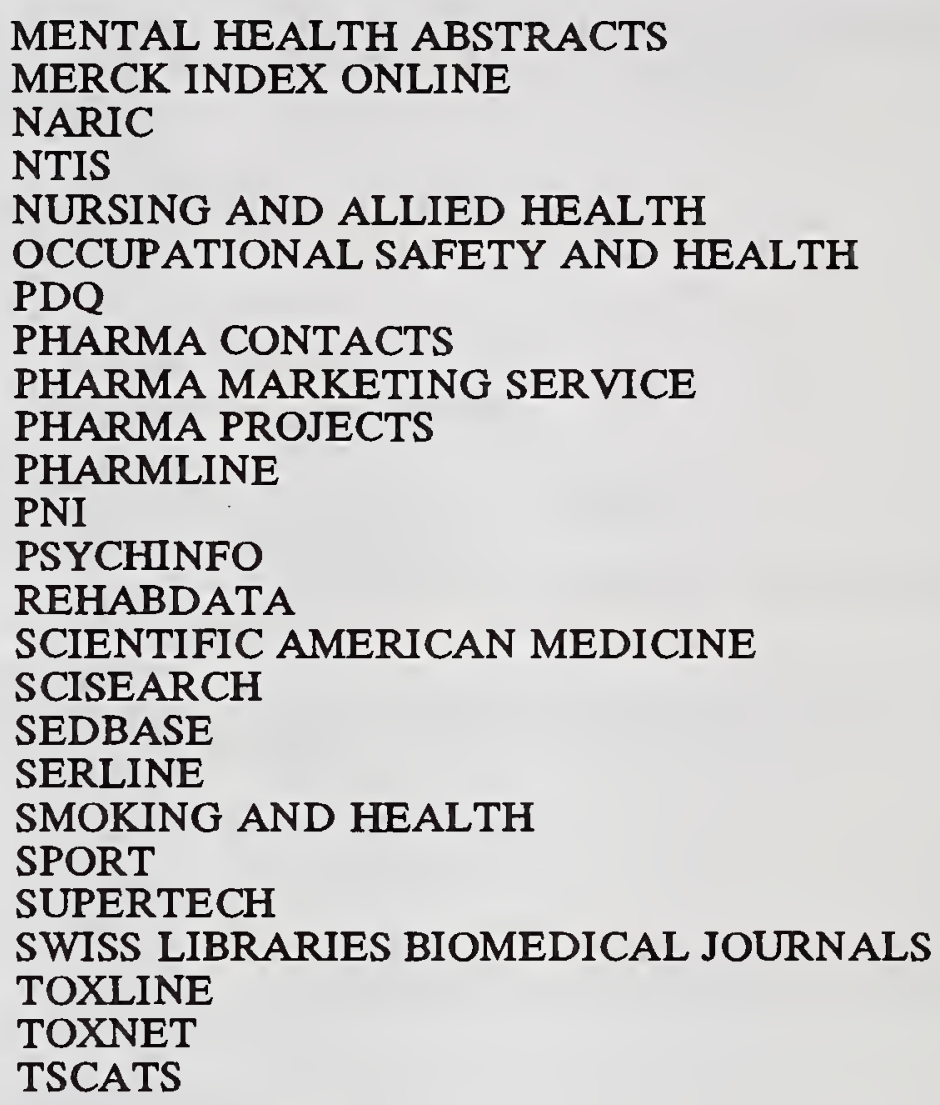

-BUYERS' GUIDE-MEASUREMENT AND CONTROL COMPENDEX

FLUIDEX

GIDEP

IHS INTERNATIONAL STANDARDS AND SPECIFICATIONS

INSPEC

ISMEC

NONFERROUS METALS ABSTRACTS

NTIS

SCISEARCH

STANDARDS AND SPECIFICATIONS

STANDARDS SEARCH

-ALUMINUM ASSOCIATION STANDARDS AND DATA APILIT

APIPAT

CHEMICAL ABSTRACTS

COMPENDEX

CORROSION

ENERGY SCIENCE AND TECHNOLOGY

ENERGYLINE

ENVIRONMENTAL BIBLIOGRAPHY

GEOARCHIVE

GEOMECHANICS ABSTRACTS

GEOREF 
INSPEC

MARTUF

MATERIALS/B

MDF/I

METADEX

MIL-HDBK-5

NONFERROUS METALS ABSTRACTS

NTIS

OCEANIC ABSTRACTS

SCISEARCH

SDIM

STEELTUF

SURFACE COATINGS ABSTRACTS

WELDASEARCH

WORLD ALUMINUM ABSTRACTS

WPI

News

-MUSIC LITERATURE INTERNATIONAL

-AMERICA: HISTORY AND LIFE

AMERICAN BANKER

AP NEWS

API ENERGY BUSINESS NEWS INDEX

AUTOMOTIVE INDUSTRY NEWS

BIOCOMMERCE ABSTRACTS AND DIRECTORY

BMA PRESS CUTTINGS

BNA DAILY NEWS

THE BOND BUYER

BUSINESS AND INDUSTRY NEWS

BUSINESSWIRE

CANADIAN BUSINESS AND CURRENT AFFAIRS CHICAGO TRIBUNE

CIN

COMPUTER NEWS FULLTEXT

CURRENT DIGEST OF THE SOVIET PRESS

DOW JONES NEWS/RETRIEVAL

EUROPEAN CHEMICAL NEWS

FACTS ON FILE

FEDERAL NEWS SERVICE

FINANCIAL TIMES COMPANY ABSTRACTS

FINANCIAL TIMES FULLTEXT

INFOMAT INTERNATIONAL BUSINESS

INVESTOR'S DAILY

JAPAN NEW WIRE: COMLINE

JERUSALEM POST ELECTRONIC EDITION

KNIGHT RIDDER FINANCIAL NEWS

KYODO NEWS SERVICE

MAGAZINE ASAP

MAGAZINE INDEX 
NATIONAL NEWSPAPER INDEX NEW YORK TIMES

NEWSEARCH

NEWSPAPER ABSTRACTS

NEWSPAPER AND PERIODICAL ABSTRACTS

NEWSWIRE ASAP

NEXIS

PAPERS

PER

PR NEWSWIRE

REUTERS

SOLE

UPI NEWS

USA TODAY DECISIONLINE

WASHINGTON POST ONLINE

WASHINGTON PRESSTEXT

WORLD AFFAIRS REPORT

Nuclear Science

- CHEMICAL ABSTRACTS

COMPENDEX

ENERGY SCIENCE AND TECHNOLOGY

ENERGYLINE

GIDEP

INSPEC

NTIS

NUCLEAR SCIENCE ABSTRACTS

POLLUTION ABSTRACTS

SCISEARCH

SPIN

Patents

-APIPAT

CHINESE PATENT ABSTRACTS

CLAIMS/CITATION

CLAIMS/PATENTS

CLAIMS/REFERENCE

CURRENT PATENTS EVALUATION

CURRENT PATENTS FAST ALERT

DEUTSCHE PATENT DATENBANK

DRUG PATENTS INTERNATIONAL

INPADOC

JAPIO

LEGAL STATUS

LITALERT

PATDATA

PATENT STATUS

TRADEMARKSCAN-FEDERAL

TRADEMARKSCAN-STATE

TRADEMARKSCAN-U.K.

USCLASS

USPA

WPI 
Philosophy

Photography

Physics

Psychology

Public Administration
- PHILOSOPHER'S INDEX

SOCIAL SCISEARCH

-IMAGING ABSTRACTS

- AEROSPACE DATABASE

CHEMICAL ABSTRACTS

COMPENDEX

ENERGY SCIENCE AND TECHNOLOGY

INSPEC

IRSS

MPDSEARCH

MSSS

NASA/RECON

NTB

NTIS

NUCLEAR SCIENCE ABSTRACTS

SCISEARCH

SPIN

WORLD ALUMINUM ABSTRACTS

- CHILD ABUSE AND NEGLECT

ECER

ECON

EMBASE

LINGUISTICS AND LANGUAGE BEHAVIOR ABSTRACTS

MENTAL HEALTH ABSTRACTS

PSYCHINFO

SOCIAL SCISEARCH

SOCIOLOGICAL ABSTRACTS

-ABI/INFORM

ARAB INFORMATION BANK

BNA DAILY NEWS

CIS

CONGRESSIONAL RECORD

COUNTRY REPORT SERVICES

FEDERAL INDEX

FEDERAL NEWS SERVICE

FEDREG

FROST \& SULLIVAN POLITICAL RISK COUNTRY

REPORTS

MANAGEMENT CONTENTS

PAIS INTERNATIONAL

PUBLIC OPINION ONLINE

SCAN-A-BID

SOCIAL SCISEARCH

UNITED STATES POLITICAL SCIENCE DOCUMENTS

WASHINGTON PRESSTEXT

WORLD AFFAIRS REPORT 
Religion

Remote Sensing

Safety

Social Sciences

Sports

Statistics
-BIBLE

RELIGION INDEX

-RESORS

- CAMBRIDGE SCIENTIFIC ABSTRACTS ENGINEERING CHEMICAL SAFETY NEWSBASE

DECHEMA

HSELINE

MSDS

MSDS-CCOHS

OCCUPATIONAL SAFETY AND HEALTH

SAFETY

-AGELINE

ARAB INFORMATION BANK

ASSIA: APPLIED SOCIAL SCIENCES INDEX AND

ABSTRACTS

CHILD ABUSE AND NEGLECT

CRIMINAL JUSTICE PERIODICAL INDEX

DRUG

EBIS-EMPLOYEE BENEFITS INFOSOURCE

ECON

FAMILY RESOURCES

FORIS

HISTORICAL ABSTRACTS

INTERNATIONAL REVIEW OF PUBLICATIONS IN SOCIOLOGY

LABORDOC

LINGUISTICS AND LANGUAGE BEHAVIOR ABSTRACTS

NCJRS

PAIS INTERNATIONAL

POPLINE

POPULATION BIBLIOGRAPHY

RSWB

SOCIAL PLANNING/POLICY AND DEVELOPMENT ABSTRACTS

SOCIAL SCISEARCH

SOCIAL WORK ABSTRACTS

SOCIOLOGICAL ABSTRACTS

SOLIS

SPORT

UNITED STATES POLITICAL SCIENCE DOCUMENTS

-SPORT

$-A S I$

CENDATA

D\&B DONNELLEY DEMOGRAPHICS 
GENERAL SUBJECT INDEX

SUBJECT

Statistics (cont.)

Textiles

Toxicology

Translations

Transportation and Utilities

Zoology
DATA BASE NAME

PTS F\&S INDEXES

PTS FORECASTS

PTS PROMT

PTS TIME SERIES

- CHEMICAL ABSTRACTS

PAPERCHEM

TEXTILE TECHNOLOGY DIGEST

TITUS

WORLD TEXTILES

WPI

-APTIC

CHEMICAL ABSTRACTS

CTCP

DHMT

EMBASE

HAZARDLINE

HAZARDOUS SUBSTANCES DATA BANK

INTERNATIONAL PHARMACEUTICAL ABSTRACTS

POLLUTION ABSTRACTS

RTECS

TOXLINE

TOXLIST

TOXNET

TSCA INITIAL INVENTORY

TSCAPP

-WORLD TRANSLATIONS INDEX

- COLD REGIONS

COMPENDEX

CONFERENCE PAPERS INDEX

ENERGY SCIENCE AND TECHNOLOGY

EPD

ISMEC

NASA/RECON

OAG ELECTRONIC EDITION

OCEANIC ABSTRACTS

PAIS INTERNATIONAL

POLLUTION ABSTRACTS

SAE GLOBAL MOBILITY

SOCIAL SCISEARCH

TRIS

VOLKSWAGENWERK

WPI

-BIOSIS PREVIEWS

ZOOLOGICAL RECORD 


\section{CROSS REFERENCE INDEX}

\section{DATA BASE OR HARD COPY}

\begin{abstract}
Bulletin of the Institute of Paper Chemistry Abstracted Business Information/Inform

Abstracts in Biocommerce

Abstracts on Tropical Agriculture

Accountants' Index

Achema Handbook Pollution Control

Achema Yearbook
\end{abstract}

ACM Guide to Computing Literature

Agricultural On-Line Access

AGRINDEX

AHL

AI Abstracts

Air Pollution Abstracts

Air Pollution Technical Information Center

Algology, Mycology and Protozoology

\section{American Banker}

American Doctoral Dissertations

American Petroleum Institute Literature

American Petroleum Institute Patents

American Statistics Index

American Theological Library Association Religion

Amino-Acids, Peptides and Proteins

Analytica Chimica Acta

Angewandte Chemie

Animal Behavior Abstracts

The Annual Book of ASTM Standards

Annual Report and Accounts

Antarctic Bibliography

Applied Catalysis

Aquatic Information Retrieval

Aquatic Sciences and Fisheries Abstracts

Architectural Periodicals Index

Architectural Books Catalogue

The Associated Press

Fudiovisual Catalog Online

Automotive Abstracts

Bacteriology

\section{Barron's}

BHRA Fluid Engineering Abstracts

Bibliographie Internationale

Bibliography and Index of Geology

Bibliography and Index of Geology Exclusive of North America

Bibliography and Index of North American Geology

Bibliography of Agriculture

Bibliography of Bioethics

Bibliography of the History of Medicine

\author{
PAPERCHEM \\ ABI/INFORM \\ BIOCOMMERCE ABSTRACTS AND DIRECTORY \\ TROPAG \\ ACCOUNTANTS \\ DETEQ \\ BIOQUIP \\ DEQUIP \\ COMPUSCIENCE \\ MATHSCI \\ AGRICOLA \\ AGRIS INTERNATIONAL \\ AMERICA: HISTORY AND LIFE \\ SUPERTECH \\ APTIC \\ APTIC \\ CAMBRIDGE SCIENTIFIC ABSTRACTS LIFE \\ SCIENCE \\ BANKER \\ DISSERTATION ABSTRACTS ONLINE \\ APILIT \\ APIPAT \\ ASI \\ RELIGION INDEX \\ CAMBRIDGE SCIENTIFIC ABSTRACTS LIFE \\ SCIENCE \\ CJELSEVIER \\ CJVCH \\ CAMBRIDGE SCIENTIFIC ABSTRACTS LIFE \\ SCIENCE \\ STANDARDS SEARCH \\ ICC INTERNATIONAL ANNUAL REPORTS \\ COLD REGIONS \\ CJELSEVIER \\ AQUIRE \\ ASFA \\ ARCHITECTURE DATABASE \\ ARCHITECTURE DATABASE \\ AP NEWS \\ AVLINE \\ SAE GLOBAL MOBILITY \\ CAMBRIDGE SCIENTIFIC ABSTRACTS LIFE \\ SCIENCE \\ DOW JONES NEWS/RETRIEVAL \\ FLUIDEX \\ PASCAL \\ GEOREF \\ GEOREF \\ GEOREF \\ AGRICOLA \\ BIOETHICS \\ HISTLINE
}




\section{CROSS REFERENCE INDEX}

Bibliography of Thesis in Geology

Bibliography on Cold Regions

Biochemistry Abstracts

Bioinpharma

Biological Abstracts

Biotechnologie-das Jahr-und Adressbuch

Biotechnology Research Abstracts

BMFT Support Catalog

BNF Nonferrous Metals Abstracts

Brands and Their Companies

Bundesanzeiger

C2C Abstracts: Japan

C2C Currents: Japan

CA Chemical Name Dictionary

Calcified Tissue Abstracts

Cancer Literature

Cancer Therapy Abstracts

Carbohydrate Research

Carcinogenesis Abstracts

CASIA

CASR

Catalog On-Line

CDI

Center for Exceptional Children

Ceramic Abstracts

CHEM Sources USA

Chemical Abstracts Chemical Name Directory

Chemical Abstracts Service Source Index

Chemical Carcinogenesis Research Information System

Chemical Dictionary On-Line

Chemical Evaluation Search and Retrieval System

Chemical Hazard Response Information System

Chemical Industry Notes

Chemicals Identified in Feral and Food Animals

Chemicals Identified in Human Biological Media

Chemoreception Abstracts

CIC's School Directory

Cliniçal Toxicology of Commercial Products

Commonwealth Agricultural Bureaux Abstracts

Comprehensive Dissertation Index

Compumath Citation Index

Computer and Control Abstracts

Computer and Information Systems

Computer Product Update

\section{GEOREF}

COLD REGIONS

CAMBRIDGE SCIENTIFIC ABSTRACTS LIFE SCIENCE

DRUGNEWS

BIOSIS PREVIEWS

BIKE

CAMBRIDGE SCIENTIFIC ABSTRACTS LIFE SCIENCE

FORKAT

NONFERROUS METALS ABSTRACTS

TRADE NAMES DATABASE

ECONOVO

ECOREGISTER

JAPAN TECHNOLOGY-JTEC

JAPAN TECHNOLOGY-JTEC

CHEMNAME

CAMBRIDGE SCIENTIFIC ABSTRACTS LIFE SCIENCE

CANCERLINE

CANCERLINE

CJELSEVIER

CANCERLINE

CHEMICAL ABSTRACTS

CHEMICAL ACTIVITY STATUS REPORT

CATLINE

DISSERTATION ABSTRACTS ONLINE

ECER

AMERICAN CERAMIC ABSTRACTS

CSCHEM

CSCORP

CHEMNAME

CASSI

CCRIS

CHEMLINE

CESARS

CHRIS

CIN

CHEMICAL EXPOSURE

CHEMICAL EXPOSURE

CAMBRIDGE SCIENTIFIC ABSTRACTS LIFE SCIENCE

THE EDUCATIONAL DIRECTORY

CTCP

CAB ABSTRACTS

DISSERTATION ABSTRACTS ONLINE

COMPUTER AND MATHEMATICS SEARCH

INSPEC

CAMBRIDGE SCIENTIFIC ABSTRACTS ENGINEERING

COMPUTER INDUSTRY SOFTWARE, SERVICES AND PRODUCTS 
Computerized Engineering Index

Computerworld

Computing Reviews

Congressional Information Service

Consumer Drug Digest

Corporate Technology Directory

Corrosion Resistance Tables

CPI

CRC Handbook of Data on Organic Compounds

Current Antimicrobial Patents

Current Cardiovascular Patents

Current Catalog

Current CNS Patents

Current Index to Journals in Education

Current Index to Statistics

Current Law Index

Current Physics Index

Current Projects in Vocational Education

Current Research Information System

Defense RDT + E On-Line System

Defense Technical Information Center

Design Institute for Physical Property Data

Development Business

Dictionary of Organic Compounds

Dictionary of Organometallic Compounds

Directory of Industry Data Sources

Directory of Online Databases

Dissertation Abstracts International

Dissertation Index

DOE Energy Data Base

Drug Info/Alcohol Use-Abuse

Drug Literature Index

DTIC

Ecological Abstracts

Ecology Abstracts

Economic Titles and Abstracts

Educational Resources Information Center

Electric Power Industry Abstracts

Electrical and Electronic Abstracts

Electric Power Database

Electronics and Communications Abstracts

Energy Abstracts

Energy Abstracts for Policy Analysis

Energy Bibliography and Index

Energy Information Abstracts

Energy Research Abstracts

Engineering Index

Entomology Abstracts

\author{
COMPENDEX \\ COMPUTER NEWS FULLTEXT \\ COMPUSCIENCE \\ MATHSCI \\ CIS \\ CONSUMER DRUG INFORMATION FULLTEXT \\ CORPTECH \\ CORROSION \\ CONFERENCE PAPERS INDEX \\ HODOC \\ CURRENT PATENTS EVALUATIONS \\ CURRENT PATENTS EVALUATIONS \\ CATLINE \\ CURRENT PATENTS EVALUATIONS \\ ERIC \\ MATHSCI \\ LEGAL RESOURCE INDEX \\ SPIN \\ RESOURCES IN VOCATIONAL EDUCATION \\ CRIS/USDA \\ DROLS \\ DROLS \\ DIPPR \\ SCAN-A-BID \\ CHAPMAN AND HALL CHEMICAL DATABASE \\ CHAPMAN AND HALL CHEMICAL DATABASE \\ INDUSTRY DATA SOURCES \\ CUADRA DIRECTORY OF ONLINE DATABASES \\ DISSERTATION ABSTRACTS ONLINE \\ DISSERTATION ABSTRACTS ONLINE \\ ENERGY SCIENCE AND TECHNOLOGY \\ DRUG \\ EMBASE \\ DROLS \\ GEOBASE \\ CAMBRIDGE SCIENTIFIC ABSTRACTS LIFE \\ SCIENCE \\ FOREIGN TRADE AND ECONOMIC \\ ABSTRACTS \\ ERIC \\ EPIA \\ INSPEC \\ EPD \\ CAMBRIDGE SCIENTIFIC ABSTRACTS \\ ENGINEERING \\ ENERGYLINE \\ ENERGY SCIENCE AND TECHNOLOGY \\ EBIB \\ ENERGYLINE \\ ENERGY SCIENCE AND TECHNOLOGY \\ COMPENDEX \\ CAMBRIDGE SCIENTIFIC ABSTRACTS LIFE \\ SCIENCE
}


Environment Abstracts

EPB

Exceptional Child Education Abstracts

Exerpta Medica

$\mathbf{F}+\mathrm{S}$ Indexes

Faculty Alert Bulletin

Fair Employment Practice Cases

FD

Federal Register Abstracts

FGI

FIND/SVP Reports and Studies Index

Foundation News

FSTA

Funk and Scott

Genetics Abstracts

Geographical Abstracts

Geological Abstracts Service

Geological Reference File

Geophysical Abstracts

German National Bibliography

German Patent Database

Government - Industry Data Exchange Program

Government Reports Announcements

Government Research Directory

GP-General Practitioner

GRA

Grant Information System

Health and Safety Sciences Abstracts

Health Planning and Administration

History of Medicine On-Line

Hospital Literature Index

HRIS Abstracts

ICO Library Monthly Entries

IFIS

Immunology Abstracts

Index Medicus

Index to Scientific and Technical Proceedings

Index to Statistics and Probability

Industrial and Applied Microbiology

Inform

Information Bank

Information Service in Mechanical Engineering

Information System for Hazardous Organics in Water

Information Technology

Inforum

Infrared Search Systems

Inorganic Crystal Structure Database

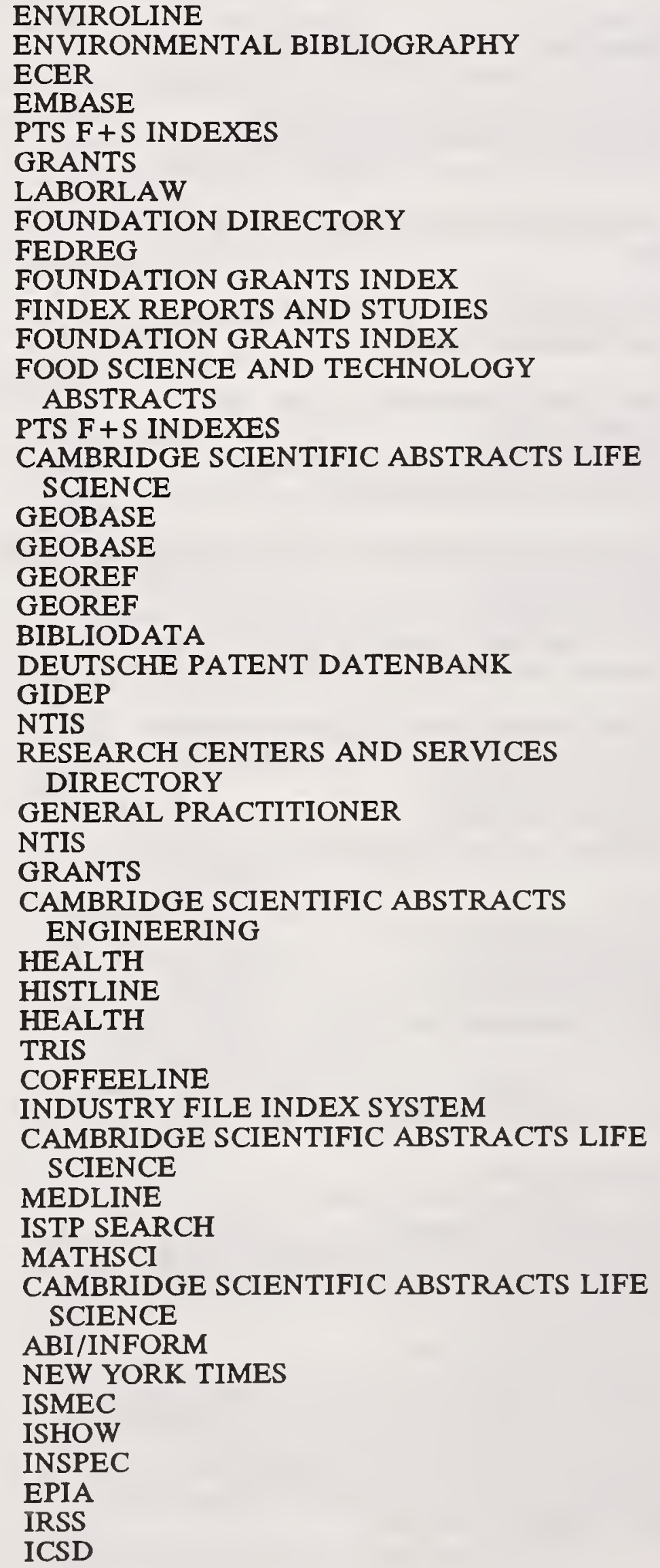




\section{CROSS REFERENCE INDEX}

\section{DATA BASE OR HARD COPY}

Inpharma

International Aerospace Abstracts

International Brands and Their Companies

International Development Abstracts

International Labour Documentation

International Research Centers Directory

International Reviews on Mathematical Education

IPA

ISMEC Bulletin

Jane's Defense Weekly

Japan Patent Information Organization

Journal AWWA

Journal of Organometallic Chemistry

Journal of Synthetic Methods

Journal of the Association of Official Analytical Chemists

Keynote Reports

Labor Arbitration Reports

Labor Relations

Language and Language Behavior Abstracts

Leisure, Recreation and Tourism Abstracts

Library and Information Science Abstracts

Library of Congress

Life Insurance Index

LLBA

\section{LRI}

Mathematical Reviews

MEDECONOMICS

MEDLARS On-Line

Metals Abstracts/Alloys Index

MGA

Microbiology Abstracts

MIMS Magazine

Mine Safety and Health Cases

Mineralogical Abstracts

Modern Language Association Bibliography

Monthly Catalog of U.S. Government Publications

MRIS Abstracts

Mutagenicity Database

NASA Tech Briefs

National Aeronautics and Space Administration

National Criminal Justice Reference Service

National Rehabilitation Information Center

National Technical Information Service

NBS Technical Note 1097
SEE

DATA BASE NAME 
Nederlands ABC Voor Handel en Industrie

Network World

Nonferrous Alert

Nuclear Magnetic Resonance Literature System

Nucleic Acids

Occupational Safety and Health Cases

Oesterreich 2000

Oil and Hazardous Materials Technical Assistance Data System

Oxford Dictionary of Quotations

PA

Packaging Abstracts

Paper and Board Abstracts

PATELL

Patent Abstracts of Japan

Patents International

PATS

Personal Computer Markets

Peterson's Annual Guides/Graduate Study

Petroleum/Energy Business News Index

Pharma Marketing News

Pharmaceutical News Index

Photographic Abstracts

Physics Abstracts

Plant Toxicity Data

Polymer/Ceramics/Composites Alert

Predicasts Aerospace/Defense Markets and Technology

Predicasts Annual Reports

Predicasts Basebook

Predicasts $\mathrm{F}+\mathrm{S}$ Indexes

Predicasts Forecasts

Predicasts Marketing and Advertising Reference Service

Predicasts New Product Announcements

Predicasts Newsletter Database

Predicasts Overview of Markets and Technology

Predicasts Promt

Predicasts Time Series

Projects in Progress

Property and Liability Insurance Index

Psychological Abstracts

Public Affairs Information Service

Reactions

Reading Abstracts

Registry of Toxic Effects of Chemical Substances

Research Centers Directory

Research in Education

Research Services Directory
HOPPENSTEDT BENELUX

COMPUTER NEWS FULLTEXT

MATERIALS/B

NMRLIT

CAMBRIDGE SCIENTIFIC ABSTRACTS LIFE SCIENCE

LABORLAW

HOPPENSTEDT AUSTRIA

OHMTADS

QUOTATIONS DATABASE

PSYCHINFO

PIRA

PIRA

PSYCHINFO

JAPIO

DRUG PATENTS INTERNATIONAL

PATDATA

COMPUTER INDUSTRY SOFTWARE, SERVICES

AND PRODUCTS

PETERSON'S GRADLINE

API ENERGY BUSINESS NEWS INDEX

PHARMA MARKETING SERVICE

PNI

IMAGING ABSTRACTS

INSPEC

PHYTOTOX

MATERIALS/B

PTS AEROSPACE/DEFENSE MARKETS AND TECHNOLOGY

PTS ANNUAL REPORTS

PTS FORECASTS

PTS F + S INDEXES

PTS FORECASTS

PTS MARKETING AND ADVERTISING

REFERENCE SERVICE

PTS NEW PRODUCT ANNOUNCEMENTS

PTS NEWSLETTER DATABASE

PTS PROMT

PTS PROMT

PTS TIME SERIES

RESOURCES IN VOCATIONAL EDUCATION

INSURANCE ABSTRACTS

PSYCHINFO

PAIS

DRUGNEWS

LINGUISTICS AND LANGUAGE BEHAVIOR ABSTRACTS

RTECS

RESEARCH CENTERS AND SERVICES DIRECTORY

ERIC

RESEARCH CENTERS AND SERVICES DIRECTORY 


\section{CROSS REFERENCE INDEX}

Retrospective Machine Readable Cataloging

Review of Metal Literature

RILA

RIVE

Robomatix Reporter

Robotics, Automation and Management in Manufacturing Bulletin

The SAE Aerospace Index

The SAE AMS Index of Aerospace Material Specifications

The SAE Handbook

SAE Quarterly Abstracts

Safety Science Abstracts

Science Abstracts

Science Citation Index

Scientific and Technical Aerospace Reports

Searchable Physics Information Notices

Selected Water Resources Abstracts

Serials On-Line

Smithsonian Science Information Exchange

Social Sciences Citation Index

Society of Automotive Engineers

Soft

\section{Software Markets}

Solid State and Superconductivity Abstracts

Sport and Recreation Index

State Department Bulletin

Steels Alert

Structure and Nomenclature Search System

SWRA

Technical Abstract Bulletin

Technical Reports in Computer Science

Telecommunication Abstracts

Telegen Reporter Review

Toxic Substances Control Act Test Submissions

Toxic Substances Control Act (TSCA) Initial Inventory

Toxicology Abstracts

Toxicology Information On-Line

Transportation Research Information Services

UFOKAT

U.S. Patent Alert

U.S. Patent Master Classification File

U.S. Patent Official Gazette

USPSD

Virology and Aids Abstracts

WAA

Wage and Hour Cases

Wall Street Journal
REMARC

METADEX

ART LITERATURE INTERNATIONAL RESOURCES IN VOCATIONAL EDUCATION SUPERTECH

RECENT ADVANCES IN MANUFACTURING

STANDARDS SEARCH

STANDARDS SEARCH

STANDARDS SEARCH

SAE GLOBAL MOBILILTY

SAFETY

INSPEC

SCISEARCH

AEROSPACE DATABASE

SPIN

WRA

SERLINE

SSIE

SOCIAL SCISEARCH

SAE GLOBAL MOBILITY

ONLINE MICROCOMPUTER SOFTWARE GUIDE AND DIRECTORY

COMPUTER INDUSTRY SOFTWARE, SERVICES AND PRODUCTS

CAMBRIDGE SCIENTIFIC ABSTRACTS ENGINEERING

SPORT

WASHINGTON PRESSTEXT

MATERIALS/B

SANSS

WRA

DROLS

MATHSCI

SUPERTECH

SUPERTECH

TSCATS

TSCA CHEMICAL SUBSTANCES INVENTORY

CAMBRIDGE SCIENTIFIC ABSTRACTS LIFE SCIENCE

TOXLINE

TRIS

UFORDAT

USPA

USCLASS

CLAIMS/PATENTS

UNITED STATES POLITICAL SCIENCE

DOCUMENTS

CAMBRIDGE SCIENTIFIC ABSTRACTS LIFE SCIENCE

WORLD ALUMINUM ABSTRACTS

LABORLAW

DOW JONES NEWS/RETRIEVAL 
CROSS REFERENCE INDEX

DATA BASE OR HARD COPY

Water Resources Abstracts

Weekly Compilation of Presidential Documents

World Patent Index

World Surface Coatings Abstracts

World Textile Abstracts

Worldcasts

WRC Information

WTA

Zentralblatt für Mathematik
SEE

DATA BASE NAME

WRA

WASHINGTON PRESSTEXT

WPI

SURFACE COATINGS ABSTRACTS

WORLD TEXTILES

PTS FORECASTS

AQUALINE

WORLD TEXTILES

MATH 



\section{BIBLIOGRAPHIC DATA SHEET}

\begin{tabular}{|ll}
\hline 1. & $\begin{array}{l}\text { PUBLCATION OR REPORT NUMBER } \\
\text { NIST / SP }-818\end{array}$ \\
\hline 2. & PERFORMING ORGANIZATION REPORT NUMBER \\
\hline 3. & $\begin{array}{l}\text { PUBLCATION DATE } \\
\text { September } 1991\end{array}$ \\
\hline
\end{tabular}

\section{TITLE AND SUBTITLE}

Data Bases Available in the Research Information Center of the National Institute of Standards and Technology*

*Available to NIST Staff and NIST Associates only

5. AUTHOR(S)

Diane Cunningham

6. PERFORMING ORGANIZATION (IF JOINT OR OTHER THAN NIST, SEE INSTRUCTIONS)

U.S. DEPARTMENT OF COMMERCE

NATIONAL INSTITUTE OF STANDARDS AND TECHNOLOGY

GAITHERSBURG, MD 20899

7. CONTRACT/GRANT NUMBEA

8. TYPE OF REPORT AND PERIOD COVERED Final

9. SPONSORING ORGANIZATION NAME AND COMPLETE ADDRESS (STREET, CITY, STATE, ZIP)

Same as Block 6

10. SUPPLEMENTARY NOTES

Supersedes NIST Special Publication 799 (September 1990)

DOCUMENT DESCRIBES A COMPUTER PROGRAM; SF-185, FIPS SOFTWARE SUMMARY, IS ATTACHED.

11. ABSTRACT (A 200-WORD OR LESS FACTUAL SUMMARY OF MOST SIGNIFICANT INFORMATION. IF DOCUMENT INCLUDES A SIGNIFICANT BIBLOGRAPHY OR LITERATURE SURVEY, MENTION IT HERE.)

Data Bases available online in the Research Information Center of the National Institute of Standards and Technology (NIST) are listed by acronym and by full title. In addition, descriptions of the data bases, dates covered, producers, hard copy counterpart, principal sources and vendors are listed. A general subject index and a cross reference index are also supplied.

12. KEY WORDS (6 TO 12 ENTRIES; ALPHABETICAL ORDER; CAPITALIZE ONLY PROPER NAMES; AND SEPARATE KEY WORDS BY SEMICOLONS)

bibliographic data bases; computerized data bases; information storage and retrieval systems; libraries, automation; machine-readable bibliographic data; numeric data bases 



\section{NIST Technical Publications}

\section{Periodical}

Journal of Research of the National Institute of Standards and Technology-Reports NIST research and development in those disciplines of the physical and engineering sciences in which the Institute is active. These include physics, chemistry, engineering, mathematics, and computer sciences.

Papers cover a broad range of subjects, with major emphasis on measurement methodology and the basic technology underlying standardization. Also included from time to time are survey articles on topics closely related to the Institute's technical and scientific programs. Issued six times a year.

\section{Nonperiodicals}

Monographs-Major contributions to the technical literature on various subjects related to the Institute's scientific and technical activities.

Handbooks-Recommended codes of engineering and industrial practice (including safety codes) developed in cooperation with interested industries, professional organizations, and regulatory bodies.

Special Publications-Include proceedings of conferences sponsored by NIST, NIST annual reports, and other special publications appropriate to this grouping such as wall charts, pocket cards, and bibliographies.

Applied Mathematics Series-Mathematical tables, manuals, and studies of special interest to physicists, engineers, chemists, biologists, mathematicians, computer programmers, and others engaged in scientific and technical work.

National Standard Reference Data Series-Provides quantitative data on the physical and chemical properties of materials, compiled from the world's literature and critically evaluated. Developed under a worldwide program coordinated by NIST under the authority of the National Standard Data Act (Public Law 90-396). NOTE: The Journal of Physical and Chemical Reference Data (JPCRD) is published bi-monthly for NIST by the American Chemical Society (ACS) and the American Institute of Physics (AIP). Subscriptions, reprints, and supplements are available from ACS, 1155 Sixteenth St., NW., Washington, DC 20056.

Building Science Series-Disseminates technical information developed at the Institute on building materials, components, systems, and whole structures. The series presents research results, test methods, and performance criteria related to the structural and environmental functions and the durability and safety characteristics of building elements and systems.

Technical Notes-Studies or reports which are complete in themselves but restrictive in their treatment of a subject. Analogous to monographs but not so comprehensive in scope or definitive in treatment of the subject area. Often serve as a vehicle for final reports of work performed at NIST under the sponsorship of other government agencies.

Voluntary Product Standards-Developed under procedures published by the Department of Commerce in Part 10, Title 15, of the Code of Federal Regulations. The standards establish nationally recognized requirements for products, and provide all concerned interests with a basis for common understanding of the characteristics of the products. NIST administers this program as a supplement to the activities of the private sector standardizing organizations.

Consumer Information Series-Practical information, based on NIST research and experience, covering areas of interest to the consumer. Easily understandable language and illustrations provide useful background knowledge for shopping in today's technological marketplace.

Order the above NIST publications from: Superintendent of Documents, Government Printing Office, Washington, DC 20402.

Order the following NIST publications-FIPS and NISTIRs-from the National Technical Information Service, Springfield, VA 22161.

Federal Information Processing Standards Publications (FIPS PUB) - Publications in this series collectively constitute the Federal Information Processing Standards Register. The Register serves as the official source of information in the Federal Government regarding standards issued by NIST pursuant to the Federal Property and Administrative Services Act of 1949 as amended, Public Law 89-306 (79 Stat. 1127), and as implemented by Executive Order 11717 (38 FR 12315, dated May 11, 1973) and Part 6 of Title 15 CFR (Code of Federal Regulations).

NIST Interagency Reports (NISTIR) - A special series of interim or final reports on work performed by NIST for outside sponsors (both government and non-government). In general, initial distribution is handled by the sponsor; public distribution is by the National Technical Information Service, Springfield, VA 22161, in paper copy or microfiche form. 


\section{U.S. Department of Commerce}

National Institute of Standards and Technology

Gaithersburg, MD 20899

Official Business

Penalty for Private Use $\$ 300$ 